U.S. Department of the Interior

U.S. Geological Survey

\title{
U.S. Geological Survey Middle Rio Grande Basin Study-Proceedings of the Fourth Annual Workshop, Albuquerque, New Mexico, February 15-16, 2000
}

U.S. Geological Survey Open-File Report 00-488

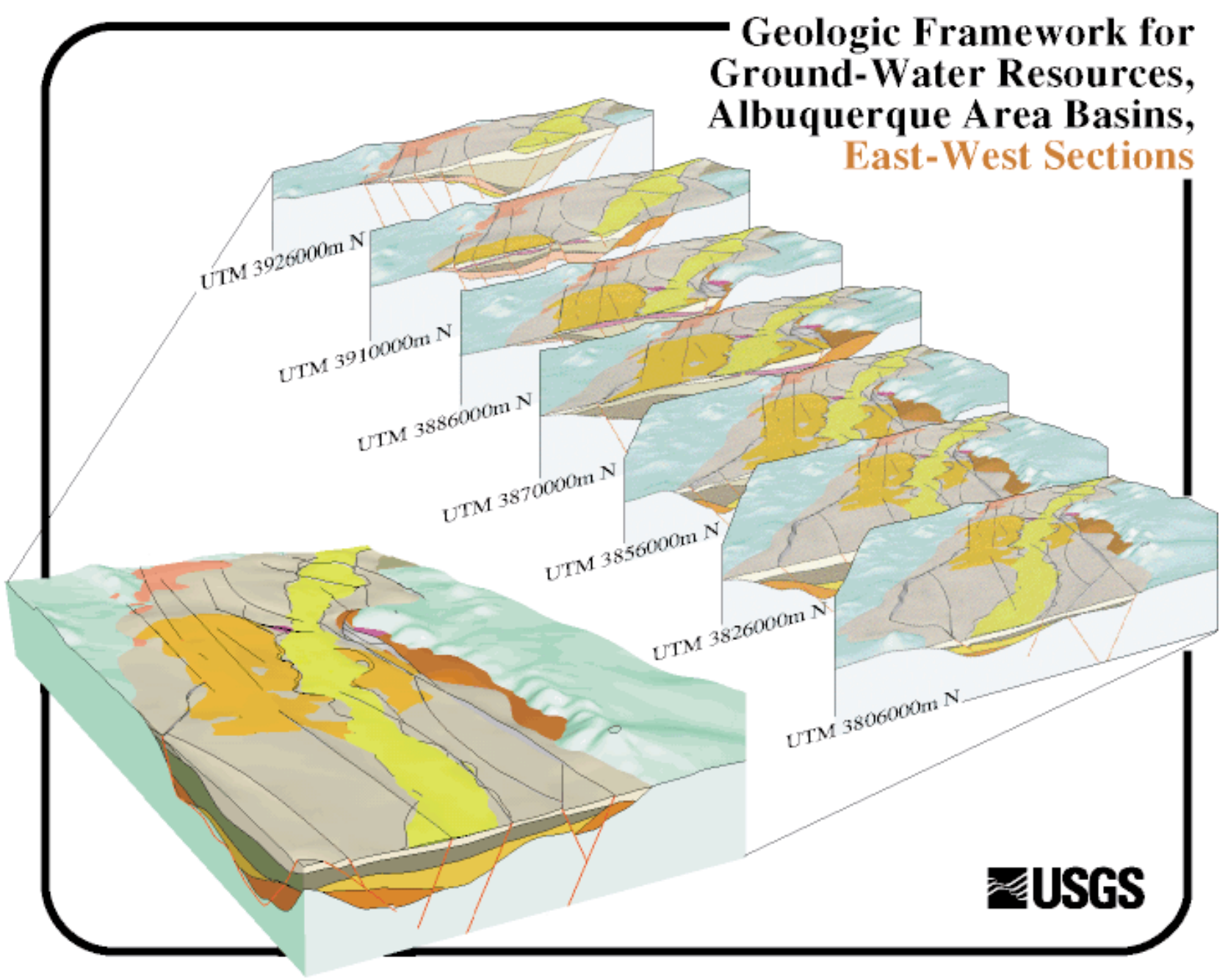

Sections through the 3-D geologic model of the Middle Rio Grande Basin, New Mexico

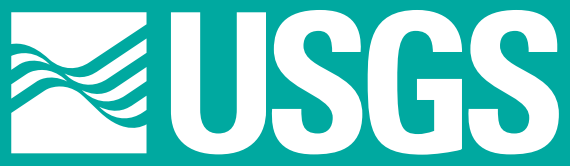




\section{The Setting}

The Middle Rio Grande Basin study is a 6-year effort by the U.S. Geological Survey and partner agencies to improve knowledge and understanding of the hydrology, geology, landforms, and land-use characteristics of this region of central New Mexico. The significance of these investigations stems from the geography and demography of this region, and from its features common to populated areas across the southwestern United States. The southwest's moderate climate, expanding employment opportunities, and abundant recreation activities have stimulated in-migration and population growth. However, these desert environments contain fragile landscapes and finite water resources that limit growth. Making room for more people poses difficult choices among competing options for undeveloped land. In today's world, those land-use choices are increasingly restricted by recognition of natural hazard potential (flood, subsidence, earthquakes, volcanic eruption, wildfire, etc.), encroachment on wildlife habitat, and the growing demands for construction materials and space to improve the urban infrastructure.

Water, the most critical factor for the prosperity of the Middle Rio Grande Basin, remains the key focus of our studies. Surface flow of the Rio Grande was fully appropriated in the early 1900's to meet needs of irrigation agriculture, Indian tribal lands, and required deliveries to Texas and Mexico. Most residential, industrial, and municipal water needs in the basin today are met by extraction of ground water. Our studies have explored hydrogeological conditions in the urban areas where extraction is currently occurring, and have used diverse methods to infer these conditions elsewhere in the basin that might support future ground-water development.

This broad valley through which the Rio Grande flows, and the mountain ranges that border it, are reflections of a geological rift that has formed over during the last 25 million years. This natural history largely determines the availability and quality of water, mineral, and land resources. The main goal of these long-term multidisciplinary studies has been to document surface and subsurface characteristics of the critical geologic and hydrologic systems and to conduct historical and process studies that evaluate relationships between the natural environment and human impacts. Our intent has been to provide credible science-based information to governmental managers and planners, and to the general public, for consideration in the critical choices that lie ahead.

\section{Front Cover}

Illustration showing serial east-west cross-sections through the 3-D geologic model of the Middle Rio Grande Basin (see Cole, this volume, paper I). Colors represent contrasting hydrostratigraphic units based on grainsize and primary depositional mode for the rift-filling sediments of the Santa Fe Group. Illustration prepared with Earth Vision 5.0 software from Dynamic Graphics, Inc.

\section{Back Cover}

3-D perspective view of the Albuquerque metropolitan area, produced with ERDAS Imagine 8.3 Virtual GIS Module using Landsat 7 Enhanced Thematic Mapper (ETM+) level 1G scene (acquired 12/17/99) draped over 10-meter digital elevation model (DEM) data. Bands 7, 4, and 2 (RGB) were processed through a high-frequency-component merge with the panchromatic band 


\section{U.S. Geological Survey Middle Rio Grande Basin Study-Proceedings of the Fourth Annual Workshop, Albuquerque, New Mexico, February 15-16, 2000}

James C. Cole, editor

U.S. Geological Survey Open-File Report 00-488

U.S.Department of the Interior

U.S. Geological Survey

Denver, Colorado

2001 


\title{
U.S. Department of the Interior \\ Gale A. Norton, Secretary
}

\author{
U.S. Geological Survey \\ Charles G. Groat, Director
}

For sale by U.S. Geological Survey, Information Services

Box 25286, Federal Center

Denver, CO 80225

Any use of trade, product, or firm names in this publication

is for descriptive purposes only and does not

imply endorsement by the U.S. Government 


\title{
Contents
}

\author{
INTRODUCTION
}

James C. Cole, editor.

\section{GEOLOGIC AND HYDROLOGIC FRAMEWORK}

A. Contributions of Gravity and Aeromagnetic Studies to Improving the Understanding of Subsurface Hydrogeology, Middle Rio Grande Basin, New Mexico

V. J. S. Grauch, David A. Sawyer, G. R. Keller, and Cindy L. Gillespie ...

B. Estimation of Hydrologic Parameters for the ground-water Model of the Middle Rio Grande Basin using Carbon-14 and Water-level Data Ward E. Sanford, L.Niel Plummer, Doug P. McAda, Laura M. Bexfield, and Scott K. Anderholm

C. Geochemical Characterization of Ground Water Flow in parts of the Santa Fe

Group Aquifer System, Middle Rio Grande Basin, New Mexico

L. Niel Plummer, Laura M. Bexfield, Scott K. Anderholm,

Ward E. Sanford, and Eurybiades Busenberg....

D. Regional Stratigraphic Framework for an Integrated Three-dimensional

Geologic Model of the Rio Grande Rift

Byron D. Stone, James C. Cole, and David A. Sawyer.....

E. Sedimentary, Stratigraphic, and Hydrologic Consequences of Syn-Depositional

Faulting in the Rio Grande Rift

Bryon D. Stone

F. Is the Top of the upper Santa Fe Group Diachronous in the Albuquerque Basin?

S.D. Connel, D.W. Love, F. Maldonado, P.B. Jackson, W.C. McIntosh, and M.C. Epps

G. Subsurface Constraints on the Hydrogeologic model of the Middle Rio Grande

Basin, New Mexico, using Airborne Time-Domain Electromagnetic Data

B.D. Rodriguez, M. Deszcz-Pan, D.A. Sawyer, and B.D. Stone

H. Geologic Map of Isleta Reservation and Contiguous Areas,

Central New Mexico

Florian Maldonado, Dave W. Love, Sean D. Connell, Janet L. Slate,

Karl E. Karlstrom, and Van S. Williams.

\section{REGIONAL GEOLOGIC AND HYDROLOGIC MODELING}

I. 3-D Geologic Modeling of Regional Hydrostratigraphic Units in the Albuquerque Segment of the Rio Grande Rift James C. Cole.

J. Revision of the Ground-water-flow Model of the Middle Rio Grande Basin, New Mexico

Douglas P. McAda, Peggy Barroll, and Ward E. Sanford 


\section{INTERACTIONS BETWEEN THE RIO GRANDE AND AQUIFER SYSTEMS}

K. Temperature Profiles of the Aquifer System Underlying the Rio Grande, Middle Rio Grande Basin, New Mexico_fourth-year status

James R. Bartolino and Richard G. Niswonger .....

L. Use of Temperature to Delineate Water Movement Between the Rio Grande, Riverside Drains, and Santa Fe Group Aquifer System at the Paseo Del Norte Bridge, Albuquerque, New Mexico James R. Bartolino and Amy E. Stewart.

M. Electromagnetic Surveys in the Rio Grande Flood Plain, Middle Rio Grande Basin, New Mexico-Fourth-year Status

James R. Bartolino and Joseph M. Sterling.

\section{RECHARGE TO AQUIFER SYSTEMS}

N. Determination of Streamflow Patterns to Estimate Stream Loss along Abo Arroyo, New Mexico

Amy E. Stewart and Jim Constantz.

0 . Determination of Streamflow Loss to Estimate Mountain-front Recharge at Bear Canyon, New Mexico

Richard Niswonger and Jim Constantz

P. Discernable Large- and Small-scale Features Affecting Recharge in Abo Arroyo and Similar Basins John R. Nimmo, Angus M. Lewis, and Kari A. Winfield

0. Hydrogeothermal Studies in the Albuquerque Basin-Preliminary Results Marshall Reiter

\section{RELATED STUDIES IN THE MIDDLE RIO GRANDE BASIN AND VICINITY}

R. Mineralogical and Geochemical Constraints On Fe and As Residence and Mobility in the Albuquerque Basin: Examples From Basin Sediments and Volcanic Rocks Mark R. Stanton, Richard F. Sanzolone, Stephen J. Sutley,

David J. Grimes, and Allen M. Meier

S. Comparison of Geomorphic and Isotopic Measurements for Erosion

in the Rio Puerco, New Mexico

Allen Gellis, Milan Pavich, Paul Bierman, Amy Ellwein, Scott Aby, and Erik Clapp...

T. Surface Geology and Liquefaction Susceptibility in the Inner Rio Grande Valley near Albuquerque, New Mexico Keith I. Kelson, Christopher S. Hitchcock, and Carolyn E. Randolph

U. New Mexico District Cooperative Program in the Middle Rio Grande Basin, FY2000 Dennis G. Woodward....

V. Partitioning of Dextral Slip in an Incipient Transverse Shear Zone of Neogene Age, Northwestern Albuquerque Basin, Rio Grande Rift, New Mexico

Richard M. Chamberlin 
1. Regional location map of the Middle Rio Grande Basin study area ............... 2

B-1. Estimates of paleorecharge for the Middle Rio Grande Basin ..................... 6

C-1. Map of the Middle Rio Grande Basin showing location of thirteen hydrochemical zones recognized in the basin

E-1. Syn-depositional fault relations of the Atrisco beds,

Albuquerque basin

E-2. Cross-section of the Calabacillas sub-basin derived from the three-dimensional geologic model of the Albuquerque basin

F-1. Schematic stratigraphic sections and altidudes of geomorphic surfaces at selected measured sections.

G-1. Airborne Time Domain Electromagnetic (TEM) Rio Rancho index map

G-2. Resistivity interpretive maps, Rio Rancho area.

I-1. Perspective view of the faulted pre-Santa Fe Group surface beneath the Albuquerque basin.

L-1. Location of the study area and annotated aerial photography of the study site.

N-1. Site map of Abo Arroyo, New Mexico...

N-2. Hydrographs from the U.S.G.S. gage on Abo Arryo...................................... 36

$\mathrm{N}-3$. Thermograph from Abo Probe Site \#3 and Hydrograph from Abo Arroyo gage

0-1. Map of Bear Canyon with surface probe locations......................................... 39

0-2. Hydraulic gradients measured in Bear Canyon............................................. 39

0-3. Plots of surface temperatures for probe sites two through five..................... 40

0-4. Sediment temperatures in Bear Canyon at TCN1 when stream-flow was present.

P-1. Darcian-SSC recharge estimates in the channel of Abo Arroyo..................... 42

P-2. Recharge subregions of Abo Arroyo ............................................................ 42

T-1. Surfical geologic map of part of the

Albuquerque West quadrangle.

T-2. Groundwater elevation map and depth-to groundwater contour map of part of the Albuquerque West quadrangle

T-3. Liquefaction susceptibility of part of the Albuquerque West quadrangle

\section{Tables} B-1. Estimates of annual recharge for the Middle Rio Grande Basin ..................... 5

C-1. Selected characteristics of thirteen hydrochemical zones delineated for the Santa Fe Group aquifer

D-1. Model units, lithologic character, and informal lithostratigraphic units used in the preliminary three-dimensional geologic model of the Middle Rio Grande Basin ..... 
CONVERSION FACTORS

\begin{tabular}{lll}
\hline \multicolumn{1}{c}{ Multiply } & \multicolumn{1}{c}{ By } & \multicolumn{1}{c}{ To obtain } \\
\hline inches (in.) & 2.54 & centimeters $(\mathrm{cm})$ \\
feet (ft) & 0.3048 & meters $(\mathrm{m})$ \\
miles (mi) & 1.609 & kilometers $(\mathrm{km})$ \\
\hline
\end{tabular}


This volume contains a collection of short papers that document some of the conclusions and results of on-going investigations related to ground-water resources of the Middle Rio Grande Basin, New Mexico. These results, and additional project reports, were presented at the Fourth Annual Middle Rio Grande Basin workshop convened in Albuquerque during February 2000. The workshop was jointly sponsored by the U.S. Geological Survey and the New Mexico Bureau of Mines and Mineral Resources as a forum for public presentation and discussion of multidisciplinary studies conducted during the previous 4 years. This considerable body of work was undertaken to improve the scientific understanding of factors that control ground-water availability and quality, and to explore land-surface characteristics that have affected the development and use of this valley that currently supports a population in excess of 600,000 .

The USGS principal science partners that have been involved in the investigations have been the New Mexico Bureau of Mines and Mineral Resources, New Mexico Office of the State Engineer, University of New Mexico, New Mexico Institute of Mining and Technology, University of Texas at El Paso, and the New Mexico Museum. Many agencies have collaborated closely in these studies, including the City of Albuquerque, Middle Rio Grande Council of Governments, Bernalillo County, numerous Indian tribal governments, and additional county and municipal departments, some of whom have provided funding to support phases of the work.

This volume is organized under topical headings for Geologic and Hydrologic Framework (papers A through H), Modeling (papers I and J), River-Aquifer Interaction (papers $\mathrm{K}$ through M), Recharge (papers N through Q), and Related Studies (papers
$\mathrm{R}$ through $\mathrm{V}$ ). These papers provide snapshots of on-going investigations, and many are expected to be published in greater detail as the joint study concludes following 2001. Interested readers are encouraged to contact the authors directly for further information.

Several papers merit attention for significant new results. The paper by Sanford and others (B) and the paper by Plummer and others (C) describe two interrelated aspects of a joint study of water chemistry and isotopic composition across the entire Middle Rio Grande Basin. The results were preliminary (February 2000) in some details, but several broad conclusions can be summarized. First, the geochemical data define distinct zones that suggest pathways of flow within the basin. Second, the groundwater model (described in papers I and J), as calibrated with geochemical and water-table data, suggests that recharge from tributary and basin-margin sources may be significantly lower than previous estimates. Independent calculations of external recharge (papers N, O, P, and Q) also suggest lower values. Third, calculations based on carbon-14 ages (B) and the ground-water model indicate that tributary and basin-margin recharge has been low for at least the last 10,000 years.

Papers on stratigraphy and sedimentology of the Santa Fe Group sediments (D, E, and F), the principal aquifers of the basin, support the growing consensus that the lithology and sequence of the Group varies considerably from place to place. These papers also describe evidence that sedimentation was strongly influenced by local faulting and that the make-up of the main aquifer units differs across major sub-basins. Geophysical data (A and $\mathrm{G}$ ) have made important contributions to the groundwater studies in locating faults and documenting growth-fault geometries. 


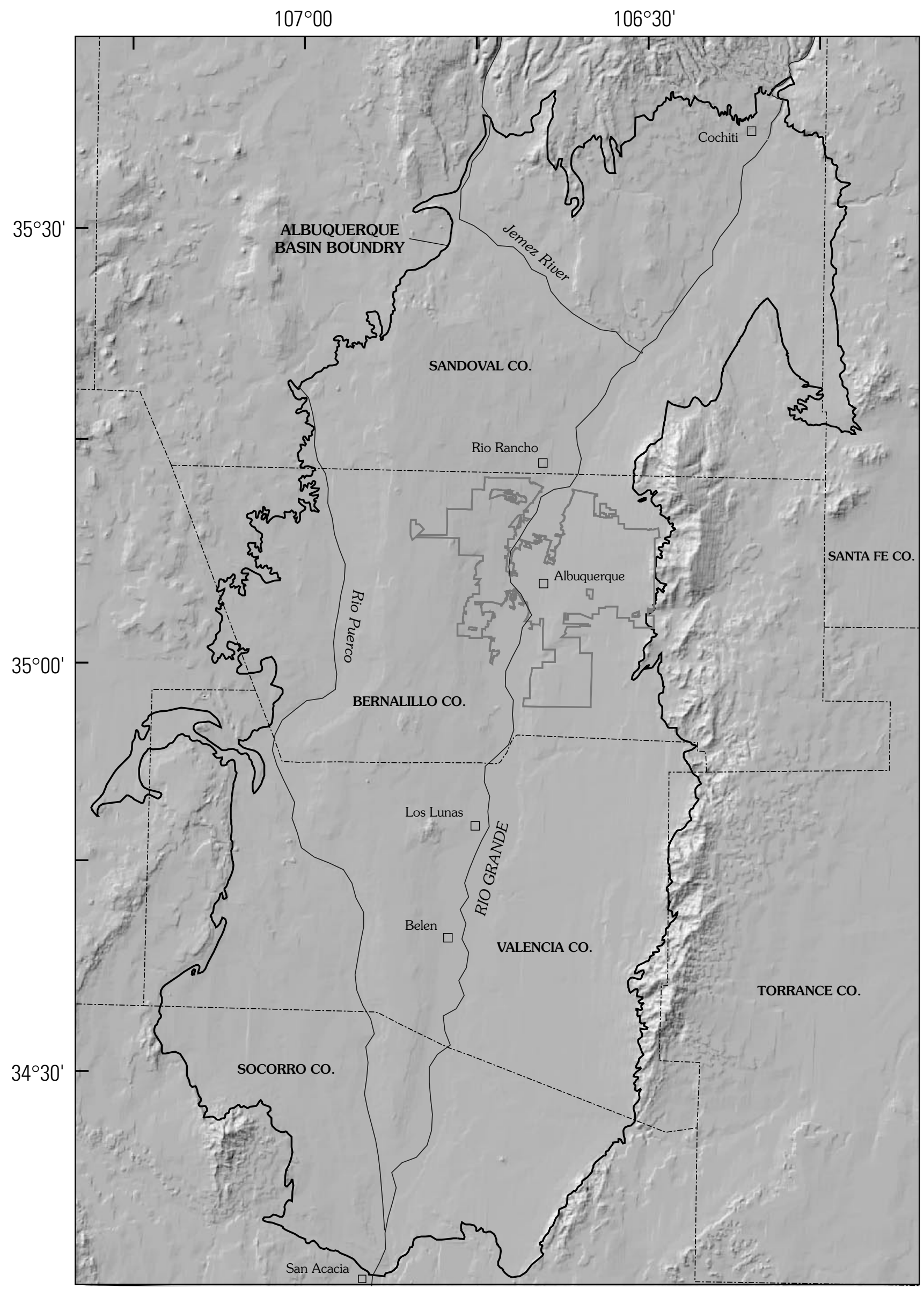

Figure 1. Regional location map of the Middle Rio Grande Basin study area. 


\title{
A. Contributions of Gravity and Aeromagnetic Studies to Improving the Understanding of Subsurface Hydrogeology, Middle Rio Grande Basin, New Mexico
}

\author{
V. J. S. Grauch ${ }^{1}$, David A. Sawyer ${ }^{2}$, G. R. Keller ${ }^{3}$, and Cindy L. Gillespie ${ }^{3}$ \\ ${ }^{1}$ U. S. Geological Survey, MS 964, Federal Center, Denver CO 80225 \\ ${ }^{2}$ U. S. Geological Survey, MS 913, Federal Center, Denver CO 80225 \\ ${ }^{3}$ Dept. of Geological Sciences, University of Texas at El Paso, El Paso TX 79968
}

\section{Introduction}

Geophysical studies for the Middle Rio Grande basin project have provided information critical to understanding the subsurface hydrogeology of the basin in several ways. Modeling of gravity data has provided thickness estimates to the base of the Santa Fe Group aquifer system, including the definition of major subbasins. High-resolution aeromagnetic data have delineated widespread intrabasinal faults that help define the lateral extent of hydrostratigraphic units. The aeromagnetic data also provided constraints on the lateral extent and depth to buried igneous rocks.

\section{Gravity Data}

The isostatic residual gravity map of the basin and vicinity was developed in cooperation with the University of Texas - El Paso (Grauch and others, 1999). The data primarily reflect variations between the low density of the poorly consolidated basin fill and the moderate to high densities of the surrounding bedrock. In general, lower gravity values correspond to thicker fill. An iterative modeling technique, which relies on gravity and other available subsurface information, was used to estimate the thickness of the Santa Fe Group. This thickness defines the base of the hydrologic model because the denser rocks that underlie the Santa Fe Group have generally lower permeabilities and do not contribute much to regional ground-water flow.

The gravity thickness model indicates several separate subbasins are filled with thick Santa Fe Group sediments within the Middle Rio Grande basin. The northernmost Santo Domingo subbasin is as much as $3.5 \mathrm{~km}$ thick under the Santa Ana Mesa. It is generally bounded on the east and west by north-south structures and on the north and south by northeast-trending structures.

The central Calabacillas subbasin, in the Albuquerque area, is generally bounded by north-south and northwest-trending structures at depth. It is separated from the Santo Domingo subbasin by the north- and northwest-trending Ziana horst, also evident in other subsurface data. The eastern gravity boundary is located near the front of the Sandia Mountains, where the Santa Fe
Group is as much as $5 \mathrm{~km}$ thick. The gravity data indicate this subbasin persists as a deep structural low as much as $10 \mathrm{~km}$ east of Russell and Snelson's (1994) eastern basin-bounding Rio Grande fault, which was interpreted from seismic reflection and drill-hole data in the area. The discrepancies between our interpretations can be explained by the lack of control in Russell and Snelson's data set at the eastern basin margin within the city of Albuquerque.

The southern Belen subbasin is a composite of basement troughs and ridges, commonly elongate north-south. Maximum thicknesses of the Santa Fe Group in the troughs range from about 3.5 to $4.5 \mathrm{~km}$. Evidence from the only deep oil well in the eastern part of the subbasin indicates that the low-density material in this area is contained in the pre-Tertiary section beneath, rather than within, an overly thick Santa Fe Group. The best explanation for these data is a Paleozoic basin section that contains a significant volume of salt (Grauch and others, 1999).

\section{Aeromagnetic Data}

High-resolution (closely sampled) aeromagnetic data have been acquired over most of the Middle Rio Grande and southern Española basins. The aeromagnetic data show expressions of faults, igneous rocks, Precambrian crystalline rocks, man-made features, and lithologic variations within the basin sediments (Grauch, 1999). The expressions of faults are the most striking and correspond to many mapped faults and to portions of faults that are not observed at the surface. Maps of the inferred faults have been integrated with other fault information to help determine the lateral extent of subsurface hydrostratigraphic units.

Detailed examination of the aeromagnetic expressions of the faults in profile-form of the flight-line data reveals a range of signatures, from symmetric curves with one inflection point to asymmetric curves with multiple inflection points. The symmetric curves match the expected response of a fault contact. The asymmetric curves have an apparent low over the fault zone, which can easily mislead interpreters to infer multiple faults or a loss of magnetization at the fault zone. However, geophysical analysis and consideration of geologic and magnetic-property observations 
imply that the curves are produced instead by a thin magnetic layer in the upthrown block offset from a thick magnetic layer in the downthrown block. The thicker, downthrown layer may have resulted from sedimentation related to growth faulting or to erosion and redeposition of magnetic sediment. This thicker layer perhaps indicates a larger volume of more permeable coarsegrained material on the downthrown side of the fault because magnetic susecptibility has been shown to increase with grain size (Hudson and others, 1999).

Volcanic and related intrusive rocks have characteristic signatures in the aeromagnetic data that can be used to infer their lateral extent in the subsurface. Depths to the top of the buried rocks were estimated from the aeromagnetic data using several standard techniques. The most extensive area of buried igneous rocks is located beneath the Rio Grande flood plain from Isleta to Los Lunas, where they are buried from 15 to $150 \mathrm{~m}$ below the surface.

In the Española basin, a characteristic aeromagnetic pattern between the Cerillos Hills and Lamy reveals the presence of the volcaniclastic Espinaso Formation where it underlies a thin cover of the Ancha Formation. The pattern terminates along an eastwest curvilinear boundary on the north that probably represents an abrupt downward ramp of the Espinaso Formation to the north below the younger, nonmagnetic Tesuque and Ancha Formations, the primary aquifers in the Santa Fe area. This boundary provides a southern limit of the thick clastic aquifer deposits. The aeromagnetic data also reveal an enigmatic, triangular pattern in the buried Espinaso Formation on the west side of Eldorado that reflects fault patterns as well as the contact between Espinaso and Galisteo Formations.

\section{References}

Grauch, V. J. S., 1999, Principal features of high-resolution aeromagnetic data collected near Albuquerque, New Mexico: New Mexico Geological Society Guidebook, 50, p. 115-118, 2 plates.

Grauch, V. J. S., Gillespie, C. L., and Keller, G. R., 1999, Discussion of new gravity maps for the Albuquerque basin area: New Mexico Geological Society Guidebook, 50, p. 119-118-124, 2 plates.

Hudson, M.R., Mikolas, Marlo, Geissman, J.W., and Allen, B.D., 1999, Paleomagnetic and rock-magnetic properties of Santa Fe Group sediments in the $98^{\text {th }}$ Street core hole and correlative surface exposures, Albuquerque basin, New Mexico: New Mexico Geological Society Guidebook, 50, p. 355-361.

Russell, L. R., and Snelson, S., 1994, Structure and tectonics of the Albuquerque Basin segment of the Rio Grande Rift: Insights from reflection seismic data: Geological Society of America Special Paper 291, p. 83-112.

\title{
B. Estimation of Hydrologic Parameters for the ground-water Model of the Middle Rio Grande Basin using Carbon-14 and Water-level Data
}

\author{
Ward E. Sanford ${ }^{1}$, L.Niel Plummer ${ }^{1}$, Doug P. McAda ${ }^{2}$, Laura M. Bexfield ${ }^{2}$, and Scott K. Anderholm ${ }^{2}$ \\ ${ }^{1}$ U. S. Geological Survey, 431 National Center, Reston VA 20192 \\ ${ }^{2}$ U. S. Geological Survey, 5338 Montgomery, NE, Suite 400, Albuquerque NM 87109-1311
}

\section{Introduction}

The question of the availability of ground water as a longterm resource in the Middle Rio Grande Basin of central New Mexico has been addressed recently by the development of ground-water flow models by the U. S. Geological Survey. An initial model (Kernodle and Scott, 1986; Kernodle and others, 1987) was later updated with a more detailed hydrogeologic framework (Kernodle and others, 1995; Kernodle, 1998), and then calibrated using inverse methods and additional hydrologic observations (Tiedeman and others, 1998). Currently, we are using carbon-14 data and the location of geochemical zones (Plummer and others, 2000) as additional constraints to further improve the groundwater model of the Middle Rio Grande Basin. The current study uses the universal inverse modeling code, UCODE (Poeter and Hill, 1998), to estimate hydraulic conductivities of hydrogeologic units as well as current and past recharge to the basin along the basin margins and tributary rivers. The water levels in the basin are simulated using MODFLOW (McDonald and Harbaugh,
1988), and travel times to wells and source-area delineation are simulated using MODPATH (Pollock, 1994).

\section{Ground-water Model and Calibration}

A simple three-dimensional geologic model compiled by Cole (2000) from mapping and well data was discretized into a three-dimensional MODFLOW grid of the basin (McAda and others, 2000). Major hydrogeologic units in the geologic model include volcanic rocks, and several units that represent the Santa Fe Group sediments, including ancestral gravels from the Rio Grande and some finer grained units that represent the middle and lower Santa Fe Group. The MODFLOW grid represented the hydrogeologic units with nine layers of variable thickness totaling more than 17,000 feet in places, and a uniform horizontal grid resolution of one square kilometer. The bottom of the model was considered to be the base of the poorly to semiconsolidated basinfill sediments as defined by geophysical observations (Grauch and others, 2000). 
Observations that were used to calibrate a steady-state model and then a transient paleohydrologic model included 200 water levels and 200 carbon-14 ages. Observed water levels were compared with simulated water levels calculated with MODFLOW, whereas carbon-14 ages were compared with travel times to individual wells calculated with MODPATH. In addition, the distribution of ground water in the aquifer system that originated from the Rio Grande and Rio Puerco were also used as constraints during the calibration. The observed carbon-14 ages and the extent of geochemical zones within the basin are described by Plummer and others (2000). The carbon-14 ages were deemed best represented by the conventional radiocarbon age corrected only for long-term variation in atmospheric input.

Hydraulic conductivities estimated for the model were not dissimilar to values that had been estimated in the previous models of Kernodle and others (1995) and Tiedeman and others (1998). As in the previous models, the hydraulic conductivity of the Rio Grande alluvium averaged about $30 \mathrm{ft} /$ day and that of the ancestral gravels from the Rio Grande in the vicinity of Albuquerque averaged about $70 \mathrm{ft} / \mathrm{day}$. In addition, the hydraulic conductivity of the volcanics unit was estimated by the inverse procedure to be higher (about $100 \mathrm{ft} /$ day) than the average for the basin while the hydraulic conductivity of a silty layer identified in the geologic model was estimated to be lower (about $0.01 \mathrm{ft} /$ day) than the average. However, the overall area-weighted hydraulic conductivity for layer 2 of the model was about $12 \mathrm{ft} /$ day compared with about $35 \mathrm{ft} /$ day in the previous two models. This result was mostly because of a lower estimate of values $(<1 \mathrm{ft} / \mathrm{day})$ in the northern regions of the basin.

\section{Impacts on Recharge Estimates}

Basin-margin and tributary recharges estimated for the model are considerably lower than values used in previous models (Table 1). These values overall in the present model were estimated to be only about 18,000 acre-feet/year. Kernodle and others (1995) had assigned recharge values that totaled 138,000 acre-feet/year based primarily on the rainfall-runoff estimation methods of Hearne and Dewey (1988). Tiedeman and others (1998) used these same values as initial estimates in an inverse modeling procedure, and then estimated a total recharge of 113,000 acre-feet/year. Although the latter value was from a rigorously calibrated model, most observations in all the previous models were water-level measurements, with few flux-based observations to constrain flow or recharge rates. The current model has 200 ground-water ages to constrain fluxes, and thus we believe our lower recharge values to be more accurate. The rainfall-runoff methods used to estimate recharge in the earlier models do not account for runoff that enters the Rio Grande, or evapotranspiration of runoff once it enters the subsurface. In addition, recharge estimates for the mountain-fronts on the eastern side of the basin have been made independently using the chloride massbalance method (Anderholm, 2000). Estimates by this method were closer to the estimates of this study than to those of the previous models (Table 1). Differences between the estimates of Anderholm (2000) and the current study could be explained by (1) movement of ground water in the mountain watersheds to basins other than the Middle Rio Grande, which would give high chloride mass-balance values, or (2) not accounting for travel time between the mountain front and the eastern model boundary. Further tests are planned with the model to investigate the second possibility.

The lower recharge estimates from the current model are also supported by the simulated water levels and the delineated source-area geochemical zones. A ground-water trough is simulated west of the Rio Grande with an associated zone of ground water that is derived from the Rio Grande. The trough and the Rio-Grande-derived ground water have been observed in the hydrology and geochemistry. The earlier models with greater recharge could not reproduce these features without invoking unrealistically high values of hydraulic conductivity within the ground-water trough.

Table B-1. Estimates of annual recharge for the Middle Rio Grande Basin [All values are in thousands of acre-feet per year.]

\begin{tabular}{|c|c|c|c|c|}
\hline & $\begin{array}{l}\text { Kernodle and others } \\
\qquad(1995)^{1}\end{array}$ & $\begin{array}{l}\text { Tiedeman and others } \\
\qquad(1998)^{2}\end{array}$ & $\begin{array}{l}\text { Anderholm } \\
(2000)^{3}\end{array}$ & $\begin{array}{l}\text { This } \\
\text { Study }^{2}\end{array}$ \\
\hline Western underflow & 19 & 13 & NA & 2 \\
\hline Jemez River leakage & 12 & 11 & NA & .03 \\
\hline Rio Puerco leakage & 8 & 4 & NA & 2 \\
\hline Northern underflow and arroyos & 28 & 27 & NA & 11 \\
\hline Sandia Mountain front & 19 & 17 & 4 & 2 \\
\hline Tijeras Arroyo & 11 & 9 & 2 & 0.5 \\
\hline Southeastern mountain fronts & 42 & 32 & 5 & 0.5 \\
\hline $\begin{array}{l}\text { Total basin-margin and tributary } \\
\text { recharge }\end{array}$ & 138 & 113 & NA & 18 \\
\hline
\end{tabular}

${ }^{1}$ Estimated from the rainfall-runoff method of Hearne and Dewey (1988) and Dewey (1988).

${ }^{2}$ Calibrated using inverse methods and hydrologic observations

${ }^{3}$ Calculated using the chloride mass-balance method 


\section{Paleorecharge}

In addition to the steady-state model, a transient paleohydrologic model was calibrated to determine if the carbon-14 data set as a whole contained information indicating that recharge rates had changed for any time during the past 30,000 years. Paleolimnological evidence from central New Mexico has indicated that the climate in the region was wetter during the last glacial maximum (20-25 ka) (Bachhuber, 1992). The paleohydrologic calibration was set up by simulating a period of 30,000 years, with an independent value of recharge being estimated every 5,000 years. These paleorecharge values were estimated simultaneously with the parameters from the original steady state model. Although uncertainty exists in the results (Fig. 1), and especially at $30 \mathrm{ka}$, the carbon-14-calibrated model clearly indicates that recharge to the basin during the last glacial maximum was significantly higher than that at present day, perhaps five to six times higher. The model results also suggest recharge may have been slightly lower than present rates at $10 \mathrm{ka}$.

\section{References}

Anderholm, S. K., 2000, Mountain-front recharge along the eastern side of the Middle Rio Grande Basin, central New Mexico: U. S. Geological Survey Water-Resources Investigations Report 00-4010, 36 p..

Bachhuber, F. W., 1992, A pre-late Wisconsin paleolimnologic record from the Estancia Valley, central New Mexico, In The last interglacial-glacial transition in North America, Clark, P. U., and Lea, P. D., (eds.): Geological Society of America Special Paper 270, p. 289-307.

Cole, J.C., 2000, 3-D geologic modeling of regional hydrostratigraphic units in the Albuquerque segment of the Rio Grande rift. This volume.

Grauch, V. J. S., Sawyer, D. A., Keller, G. R., and Gillespie, C. L., 2000, Contributions of gravity and aeromagnetic studies to improving the understanding of the subsurface hydrogeology, Middle Rio Grande Basin, New Mexico. This volume.

Hearne, G. A., and Dewey, J. D., 1988, Hydrologic analysis of the Rio Grande Basin north of Embudo, New Mexico, Colorado and New Mexico: U. S. Geological Survey Water-Resources Invest. Report 86-4113, $244 \mathrm{p}$.

Kernodle, J. M., 1998, Simulation of ground-water flow in the Albuquerque Basin, Central New Mexico, 1901-1995, with projections to 2020: U. S. Geological Survey Water-Resources Investigations Report 96209, $54 \mathrm{p}$.

Kernodle, J. M., McAda, D. P., and Thorn, C. R., 1995, Simulation of ground-water flow in the Albuquerque Basin, Central New Mexico, 1901-1994, with projections to 2020: U. S. Geological Survey WaterResources Investigations Report 94-4251, 114 p.

Kernodle, J. M., Miller, R. S., and Scott, W. B., 1987, Three-dimensional model simulation of transient ground-water flow in the

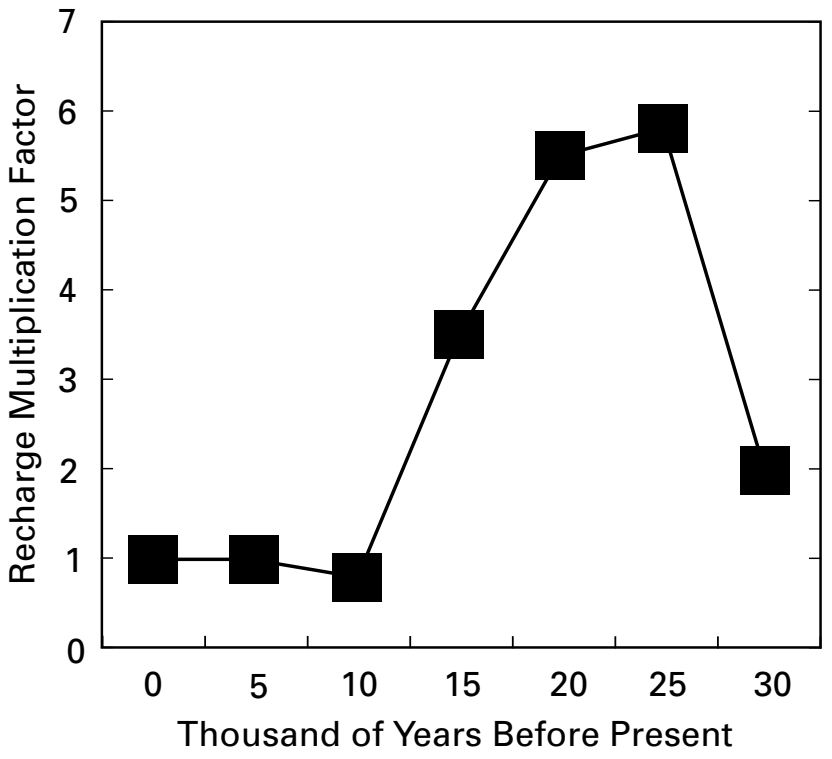

Figure B-1. Estimates of paleorecharge for the Middle Rio Grande Basin representing the best fit of the observations to the model with independent recharge multiplication factors assigned every 5,000 years.

Albuquerque-Belen Basin, New Mexico: U. S. Geological Survey Water-Resources Investigations Report 86-4194, 86 p.

Kernodle, J. M., and Scott, W. B., 1986, Three-dimensional model simulation of steady-state ground-water flow in the Albuquerque-Belen Basin, New Mexico: U. S. Geological Survey Water-Resources Investigations Report 84-4353, 58 p.

McAda, D. P., Barroll, P., and Sanford, W. E., 2000, Revision of the groundwater flow model of the Middle Rio Grande Basin. This volume.

McDonald, M. G., and Harbaugh, A. W., 1988, A modular three-dimensional finite-difference ground-water flow model: U. S. Geological Survey Techniques of Water-Resources Investigations, book 6 , chapter A1, variously paged.

Plummer, L. N., Bexfield, L. M., Anderholm, S. K., Sanford, W. E., and Busenberg, E., 2000, Geochemical characterization of ground-water flow in parts of the Santa Fe Group aquifer system, Middle RioGrande Basin, New Mexico. This volume.

Poeter, E. P., and Hill, M. C., 1998, Documentation of UCODE, a computer code for universal inverse modeling: U. S. Geological Survey Water-Resources Investigations Report 98-4080, 116 p.

Pollock, D. W., 1994, User's guide for MODPATH/MODPATH-PLOT, version 3: A particle tracking post-processing package for MODFLOW, the U.S. Geological Survey finite-difference ground-water flow model: U.S. Geological Survey Open-File Report 94-464, variously paged.

Tiedeman, C. R., Kernodle, J. M., and McAda, D. P., 1998, Application of nonlinear-regression methods to a ground-water flow model of the Albuquerque Basin, New Mexico: U. S. Geological Survey WaterResources Investigations Report 98-4172, 90 p. 


\title{
C. Geochemical Characterization of Ground Water Flow in Parts of the Santa Fe Group Aquifer System, Middle Rio Grande Basin, New Mexico
}

\author{
L. Niel Plummer ${ }^{1}$, Laura M. Bexfield ${ }^{2}$, Scott K. Anderholm², Ward E. Sanford ${ }^{1}$, \\ and Eurybiades Busenberg ${ }^{1}$ \\ ${ }^{1}$ U.S. Geological Survey, 432 National Center, Reston VA 20192 \\ ${ }^{2}$ U.S. Geological Survey, 5338 Montgomery, NE, Suite 400, Albuquerque NM 87109-1311
}

\section{Introduction and Data Sources}

Data on the chemical and isotopic composition of ground water in parts of the Santa Fe Group aquifer system, Middle Rio Grande Basin, New Mexico, were mapped and used to identify thirteen water-quality zones that have unique chemical and isotopic characteristics (Figure C-1). The water-quality zones were interpreted as representing sources of recharge to the basin (Zones 1-12) or ground-water discharge from the basin (Zone 13). The classification is based on chemical and isotopic analyses of water from 275 wells sampled as a part of the U.S. Geological Survey's Middle Rio Grande Basin Study. The data include major and minor-element chemistry (30 elements), oxygen-18 $\left({ }^{18} \mathrm{O}\right)$ and deuterium $\left({ }^{2} \mathrm{H}\right)$ content of water, carbon- $13\left({ }^{13} \mathrm{C}\right)$ and carbon-14 $\left({ }^{14} \mathrm{C}\right)$ content of dissolved inorganic carbon (DIC), sulfur-34 $\left({ }^{34} \mathrm{~S}\right)$ content of dissolved sulfate, tritium $\left({ }^{3} \mathrm{H}\right)$, and contents of selected dissolved gases (including dissolved oxygen (DO), nitrogen $\left(\mathrm{N}_{2}\right)$, argon $(\mathrm{Ar})$, methane $\left(\mathrm{CH}_{4}\right)$, helium $(\mathrm{He})$, tritiogenic helium-3 $\left({ }^{3} \mathrm{He}\right.$ ), chlorofluorocarbons (CFCs: CFC-11, CFC-12, CFC-13), sulfur hexafluoride $\left(\mathrm{SF}_{6}\right)$, neon $(\mathrm{Ne})$, and carbon dioxide $\left.\left(\mathrm{CO}_{2}\right)\right)$. Most waters were sampled from relatively shallow depths (typically the upper 150 feet of the aquifer), but some were sampled from depths of more than 1500 feet below the water table.

\section{Hydrochemical Zones}

Most of the chemical and isotopic data can be mapped throughout the basin, and many of the contour lines of equal concentration align parallel to the predominant north to south direction of ground-water flow. There is little effect of geochemical reactions on radiocarbon activity along flow paths in the primarily siliciclastic basin-fill sediment. Therefore, the ${ }^{14} \mathrm{C}$ age of DIC seems best represented by the (uncorrected) Conventional Radiocarbon Age, and ranges from modern to more than $30 \mathrm{ka}$ BP. Deuterium contents for the various sources of ground-water recharged to the basin are relatively distinctive. Based on 2.3 years of data collected monthly at selected surface-water sites, the median ${ }^{2} \mathrm{H}$ content of Rio Grande water is $-89.2 \%$ oo, and mountain-front recharge water at the base of the Sandia mountains is $-84.2 \%$. Limited isotopic data from the Jemez river near Jemez, NM, and the Rio Puerco near Hwy 6 indicate average ${ }^{2} \mathrm{H}$ contents of -83.6 and $-58.6 \%$, respectively.
Table C-1 summarizes the median values for most of the selected water-quality parameters that are characteristic for each hydrochemical zone. Zone recognition was based on varied sub-sets of the chemical and isotopic constituents. Table C-1 also includes the median values for all 275 basin-wide samples. In the discussion that follows, reference to "elevated" or "lower" concentrations or values, or "depleted" or "enriched" isotopic composition are referenced relative to the respective median values for the entire basin (Table C-1), unless otherwise stated. Additional data on $\mathrm{Li}, \mathrm{V}, \mathrm{U}, \mathrm{B},{ }^{34} \mathrm{~S}$, and ${ }^{13} \mathrm{C}$ (not included in Table $\mathrm{C}-1$ ) were used in a few cases to delineate zone boundaries.

\section{Northern Zones}

Several sources of ground-water recharge in the northern part of the basin can be recognized (Figure C-1). Zone 1 (northern mountain-front recharge) occurs in the northeast part of the basin and probably represents water recharged along the southern flanks of the Jemez Mountains (Figure C-1). Zone 1 water is characterized by relatively low specific conductance and $\mathrm{pH}$, by elevated ${ }^{2} \mathrm{H}$ and dissolved $\mathrm{SiO}_{2}$, and has a median radiocarbon age of $8.8 \mathrm{ka} \mathrm{BP}$. Zone 1 water occurs to depths greater than 200 feet at the northeast basin margin but may be relatively thin (possibly less than 50 feet) elsewhere. Zone 2 (northern intra-basin recharge) is thought to represent lower-elevation recharge from arroyos in the northern part of the basin (Figure C-1). Relatively low specific conductance and dissolved $\mathrm{SiO}_{2}$ are distinguishing characteristics of Zone 2 water. Water from Zone 2 is also elevated in ${ }^{2} \mathrm{H}$ and dissolved $\mathrm{NO}_{3}$. The median age of water in Zone 2 is $8.8 \mathrm{ka} \mathrm{BP}$, and the vertical extent of the water is possibly less than 200 feet. Zone 3 (inflow along the northern basin margin) occurs beneath Zones 1 and 2 in the northern part of the basin, extends under part of Zone 12 that parallels the Rio Grande, and occurs at the water table throughout the central part of the basin, finally converging at the Rio Grande in the southern part of the basin (Figure C-1). Zone 3 contains the oldest waters sampled in the basin and is thought to represent recharge from the Jemez Mountains north of the basin, primarily during the last glacial period. Zone 3 water is a $\mathrm{Na}-\mathrm{HCO}_{3}-\mathrm{SO}_{4}$-type and has a median age of $19.9 \mathrm{ka} \mathrm{BP}$. The water is elevated in specific conductance, As, $\mathrm{V}$ and $\mathrm{pH}$. Relative to Zones 1 and 2, Zone 3 water is elevated in dissolved $\mathrm{SO}_{4}$ and depleted in ${ }^{2} \mathrm{H}$ content. 
Table C-1. Selected characteristics of the Thirteen hydrochemical zones delineated for the Santa Fe Group aquifer system of the Middle Rio Grande Basin.

[Bracketed data were not necessary in distinquishing a particular hydrochemical zone but are provided for informational purposes. n, number of samples; $\delta \mathrm{D}$, deuterium content; \%o, per mil; ka BP, thousands of years before present; SC, specific conductance; $\mu \mathrm{S} / \mathrm{cm}$, microsiemens per centimeter at 25 degrees Celsius; su, standard units; DO, dissolved oxygen; mg/L, milligrams per liter; $\mu \mathrm{g} / \mathrm{L}$, micrograms per liter; na, not applicable]

\begin{tabular}{|c|c|c|c|c|c|c|}
\hline $\begin{array}{c}\text { Zone } \\
\text { Source } \\
\text { Characteristic } \\
\text { Water Type } \\
\text { Number of samples }\end{array}$ & & $\begin{array}{c}1 \\
\text { Northern mountain- } \\
\text { front recharge } \\
\mathrm{Ca}-\mathrm{HCO}_{3} \\
\mathrm{n}=16\end{array}$ & $\begin{array}{c}2 \\
\text { Northern intra-basin } \\
\text { recharge } \\
\text { Ca-Na-HCO } \\
n=10\end{array}$ & $\begin{array}{c}3 \\
\text { Ground-water inflow } \\
\text { along the northern } \\
\text { basin margin } \\
\mathrm{Na}-\mathrm{HCO}_{3}-\mathrm{SO}_{4} \\
\mathrm{n}=44\end{array}$ & $\begin{array}{c}4 \\
\text { Ground-water inflow } \\
\text { from the western } \\
\text { basin margin } \\
\mathrm{Na}-\mathrm{Cl}-\mathrm{SO}_{4} \\
\mathrm{n}=10\end{array}$ & 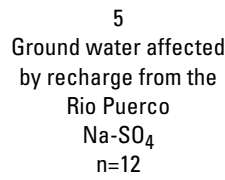 \\
\hline \multirow{14}{*}{$\begin{array}{c}\text { M edian } \\
\text { V alues of } \\
\text { Selected } \\
\text { Param eters }\end{array}$} & $\delta \mathrm{D}(\%)$ & -79 & -63 & -97 & -64 & $\begin{array}{l}-63 \\
\end{array}$ \\
\hline & ${ }^{14} \mathrm{C}$ age $(\mathrm{ka} \mathrm{BP})$ & 8.8 & 8.8 & 19.5 & 20.4 & 8.1 \\
\hline & $\mathrm{SC}(\mu \mathrm{S} / \mathrm{cm})$ & 380 & 390 & 590 & 3,300 & 2,400 \\
\hline & $\mathrm{pH}(\mathrm{su})$ & 7.5 & [7.8] & 8.3 & [7.6] & [7.5] \\
\hline & $\mathrm{DO}(\mathrm{mg} / \mathrm{L})$ & [5.1] & {$[6.8]$} & 3.1 & [4.9] & {$[3.0]$} \\
\hline & $\mathrm{Cl}(\mathrm{mg} / \mathrm{L})$ & [9.5] & {$[6.2]$} & [12] & 530 & 180 \\
\hline & $\mathrm{SO}_{4}(\mathrm{mg} / \mathrm{L})$ & 25 & 35 & 95 & 670 & 980 \\
\hline & $\mathrm{HCO}_{3}(\mathrm{mg} / \mathrm{L})$ & [150] & [140] & [170] & [250] & [180] \\
\hline & $\mathrm{NO}_{3}(\mathrm{mg} / \mathrm{L})$ & {$[0.6]$} & 5.2 & 1.3 & [1.1] & [1.5] \\
\hline & $\mathrm{Ca}(\mathrm{mg} / \mathrm{L})$ & [39] & [29] & {$[10]$} & 130 & {$[170]$} \\
\hline & $\mathrm{Na}(\mathrm{mg} / \mathrm{L})$ & [26] & [47] & [100] & 450 & 280 \\
\hline & $\mathrm{K}(\mathrm{mg} / \mathrm{L})$ & [5.4] & {$[6.2]$} & [4.1] & [14] & [12] \\
\hline & $\mathrm{SiO}_{2}(\mathrm{mg} / \mathrm{L})$ & 47 & 28 & 28 & [21] & [26] \\
\hline & As $(\mu \mathrm{g} / \mathrm{L})$ & {$[5.1]$} & {$[9.6]$} & 21 & {$[1.8]$} & {$[1.1]$} \\
\hline $\begin{array}{c}\text { Zone } \\
\text { Source } \\
\text { Characteristic } \\
\text { Water Type } \\
\text { Number of samples }\end{array}$ & & $\begin{array}{c}6 \\
\text { Southwestern } \\
\text { mountain-front } \\
\text { recharge } \\
\text { Ca-Na-Mg-HCO } \\
\text { n=2 }\end{array}$ & $\begin{array}{c}7 \\
\text { Ground-water affected by } \\
\text { recharge from } \\
\text { Abo Arroyo } \\
\mathrm{Ca}-\mathrm{SO}_{4} \\
\mathrm{n}=5\end{array}$ & $\begin{array}{c}8 \\
\text { Eastern mountain front } \\
\text { recharge - } \\
\begin{array}{c}\text { Ca-Na-HCO } \\
n=47\end{array}\end{array}$ & $\begin{array}{c}9 \\
\text { Ground-water inflow } \\
\text { from the Tijeras } \\
\text { fault zone } \\
\text { Ca- } \mathrm{HCO}_{3}-\mathrm{SO}_{4} \\
\mathrm{n}=8\end{array}$ & $\begin{array}{c}10 \\
\text { Ground water affected } \\
\text { by recharge from } \\
\text { Tijeras Arroyo } \\
\text { Ca-HCO } \\
\text { n=6 }\end{array}$ \\
\hline \multirow{14}{*}{$\begin{array}{c}\text { Median } \\
\text { Values of } \\
\text { Selected } \\
\text { Parameters }\end{array}$} & $\delta \mathrm{D}(\% \circ)$ & -64 & -64 & -81 & -74 & -75 \\
\hline & ${ }^{14} \mathrm{C}$ age $(\mathrm{ka} \mathrm{BP})$ & 7.7 & 9.4 & 5.2 & 16.2 & 3.2 \\
\hline & $\mathrm{SC}(\mu \mathrm{S} / \mathrm{cm})$ & 590 & 920 & 380 & 1,300 & 620 \\
\hline & $\mathrm{pH}(\mathrm{su})$ & [8.0] & [7.4] & [7.5] & 7.1 & 7.4 \\
\hline & $\mathrm{DO}(\mathrm{mg} / \mathrm{L})$ & [3.7] & [5.6] & 5.5 & [4.1] & {$[6.7]$} \\
\hline & $\mathrm{Cl}(\mathrm{mg} / \mathrm{L})$ & {$[26]$} & 24 & 7.7 & 87 & [29] \\
\hline & $\mathrm{SO}_{4}(\mathrm{mg} / \mathrm{L})$ & 80 & 310 & 34 & {$[150]$} & 110 \\
\hline & $\mathrm{HCO}_{3}(\mathrm{mg} / \mathrm{L})$ & [230] & {$[170]$} & 170 & 290 & [220] \\
\hline & $\mathrm{NO}_{3}(\mathrm{mg} / \mathrm{L})$ & [0.6] & [1.4] & [0.4] & {$[1.0]$} & 3.3 \\
\hline & $\mathrm{Ca}(\mathrm{mg} / \mathrm{L})$ & [39] & 91 & [48] & 130 & [80] \\
\hline & $\mathrm{Na}(\mathrm{mg} / \mathrm{L})$ & [44] & [49] & {$[22]$} & [87] & [29] \\
\hline & $\mathrm{K}(\mathrm{mg} / \mathrm{L})$ & [3.2] & [3.4] & 2.0 & {$[4.6]$} & [3.5] \\
\hline & $\mathrm{SiO}_{2}(\mathrm{mg} / \mathrm{L})$ & [14] & [22] & 26 & [23] & [23] \\
\hline & As $(\mu \mathrm{g} / \mathrm{L})$ & [1.1] & [2.6] & [1.7] & [2.0] & [1.0] \\
\hline \multirow{2}{*}{$\begin{array}{c}\text { Source } \\
\\
\text { Characteristic } \\
\text { Water Type } \\
\text { Number of samples }\end{array}$} & & $\begin{array}{l}11 \\
\text { Ground-water inflow } \\
\text { from the northeast } \\
\text { basin margin }\end{array}$ & $\begin{array}{l}12 \\
\text { Ground water recharge } \\
\text { from the Rio Grande }\end{array}$ & $\begin{array}{c}13 \\
\text { Ground water discharge } \\
-\end{array}$ & $\begin{array}{l}\text { All Zones } \\
\text { na }\end{array}$ & \\
\hline & & $\begin{array}{c}\mathrm{Ca}-\mathrm{HCO}_{3}-\mathrm{SO}_{4} \\
\mathrm{n}=7\end{array}$ & $\begin{array}{c}\mathrm{Ca}-\mathrm{Na}-\mathrm{HCO}_{3} \\
\mathrm{n}=105\end{array}$ & $\begin{array}{c}\text { Ca-Na-Cl-SO } \\
n=3\end{array}$ & $\begin{array}{c}n a \\
n=275\end{array}$ & \\
\hline \multirow{14}{*}{$\begin{array}{c}\text { Median } \\
\text { Values of } \\
\text { Selected } \\
\text { Parameters }\end{array}$} & $\delta \mathrm{D}(\% \circ)$ & -69 & -95 & -91 & -90 & \\
\hline & ${ }^{14} \mathrm{C}$ age (ka BP) & 10.0 & 4.6 & 17.9 & 8.1 & \\
\hline & $\mathrm{SC}(\mu \mathrm{S} / \mathrm{cm})$ & 1,300 & 430 & 2,500 & 470 & \\
\hline & $\mathrm{pH}(\mathrm{su})$ & 7.6 & 7.7 & [7.7] & 7.7 & \\
\hline & $\mathrm{DO}(\mathrm{mg} / \mathrm{L})$ & {$[6.6]$} & 0.1 & 0.1 & 1.9 & \\
\hline & $\mathrm{Cl}(\mathrm{mg} / \mathrm{L})$ & [22] & 16 & 680 & 16 & \\
\hline & $\mathrm{SO}_{4}(\mathrm{mg} / \mathrm{L})$ & 400 & 63 & [290] & 67 & \\
\hline & $\mathrm{HCO}_{3}(\mathrm{mg} / \mathrm{L})$ & {$[170]$} & {$[160]$} & [160] & 160 & \\
\hline & $\mathrm{NO}_{3}(\mathrm{mg} / \mathrm{L})$ & [1.9] & {$[0.1]$} & {$[0.4]$} & 0.5 & \\
\hline & $\mathrm{Ca}(\mathrm{mg} / \mathrm{L})$ & {$[100]$} & [42] & [93] & 41 & \\
\hline & $\mathrm{Na}(\mathrm{mg} / \mathrm{L})$ & [87] & [29] & [210] & 44 & \\
\hline & $\mathrm{K}(\mathrm{mg} / \mathrm{L})$ & {$[4.4]$} & 6.7 & [11] & 5.3 & \\
\hline & $\mathrm{SiO}_{2}(\mathrm{mg} / \mathrm{L})$ & [31] & 53 & [29] & 33 & \\
\hline & As $(\mu \mathrm{g} / \mathrm{L})$ & {$[2.2]$} & [5.5] & [8.0] & 5.0 & \\
\hline
\end{tabular}




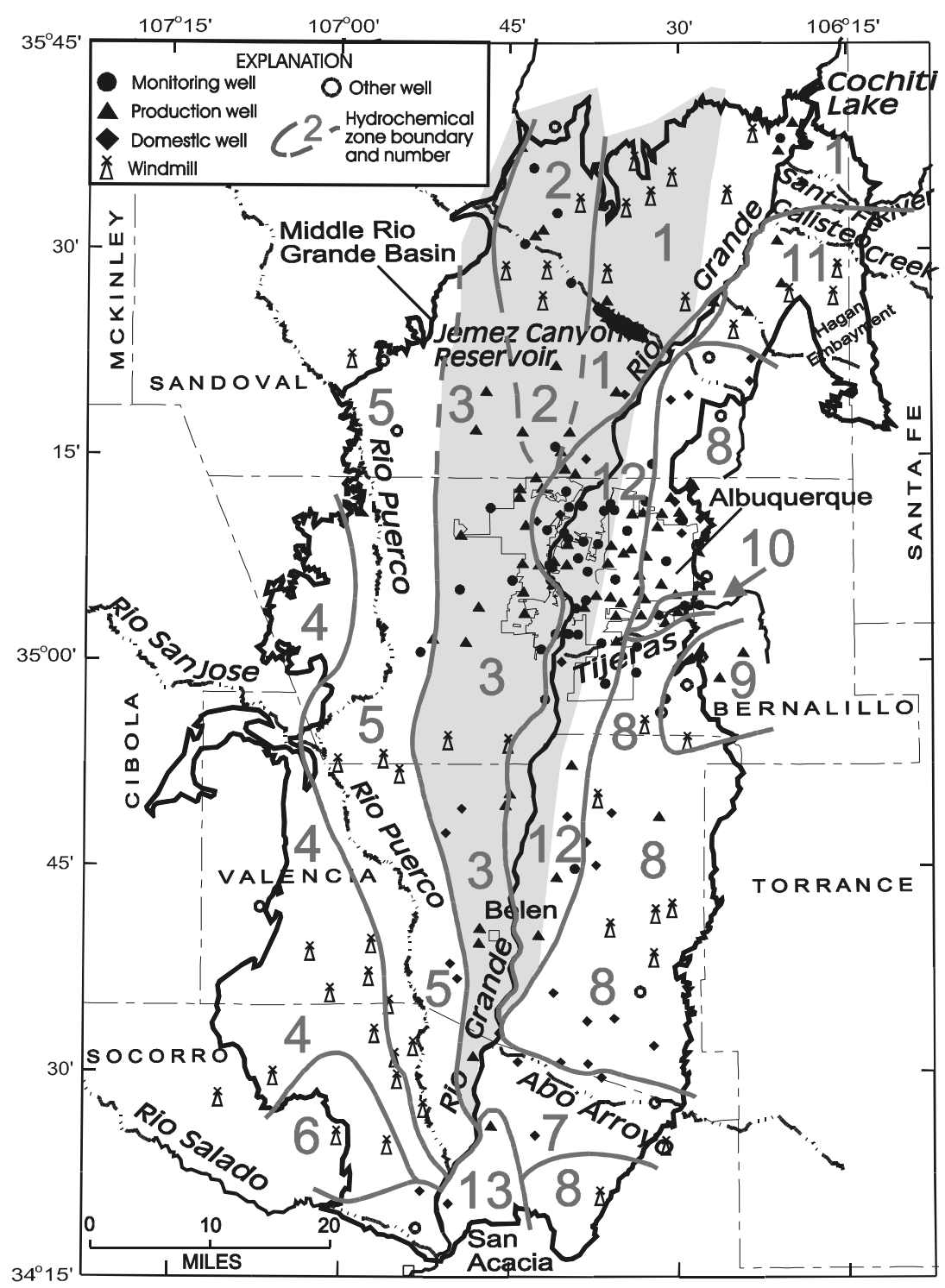

Figure C-1. Map of the Middle Rio Grande Basin showing location of thirteen hydrochemical zones recognized in the basin. Shading represents the likely extent of Zones 3 water under Zones 1, 2, and 12.

\section{Western Zones}

There appear to be three major sources of ground-water recharge near the western edge of the basin. Zone 4 (inflow from the western basin margin) represents a mixture of old ground water that seeps into the basin from Pennsylvanian through Cretaceous sedimentary rocks along the western basin margin and recharge from arroyos and the Rio Puerco. Zone 4 water has some of the highest specific conductance of any water in the basin, as well as elevated ${ }^{2} \mathrm{H}$ and $\mathrm{Cl}$, and is predominantly a $\mathrm{Na}-\mathrm{Cl}-\mathrm{SO}_{4}$ type water. Zone 4 water, which has a median age of $20.4 \mathrm{ka}$ BP is likely to occur to considerable depth in the southwest part of the basin, although this cannot be confirmed because of the limited number of wells and relatively shallow well construction in the area. Zone 5 occurs parallel to the Rio Puerco throughout the basin and represents primarily recharge from the Rio Puerco. It is characterized by relatively high ${ }^{2} \mathrm{H}$ content, specific conductance, $\mathrm{SO}_{4}$, and is predominantly $\mathrm{Na}-\mathrm{SO}_{4}$-type water. The median age is $8.1 \mathrm{ka} \mathrm{BP}$, but near the Rio Puerco the water is younger. Zone 5 water is known to occur to at least 250 feet below the water table. Zone 6 (southwestern mountain-front recharge) occurs in the southwest corner of the basin and probably represents recharge occurring along the flanks of Ladron Peak. The two water samples identified from this source have relatively low specific conductance and dissolved $\mathrm{SO}_{4}$ relative to water from Zones 4 and 5 . The water appears to be a Ca-Na-Mg- $\mathrm{HCO}_{3}$-type water with elevated ${ }^{2} \mathrm{H}$ content. Total depth of this zone is unknown because of limited data. The radiocarbon age averages $7.7 \mathrm{ka}$ BP.

\section{Eastern Zones}

Several individual sources along the eastern edge of the basin contribute to the overall ground-water recharge in this area. Zone 7 (recharge from Abo Arroyo) occurs in the southeast part of the basin (Figure C-1) and appears to be eastern mountain-front 
recharge affected by infiltration from Abo Arroyo. The water is characterized by elevated specific conductance, $\mathrm{SO}_{4}, \mathrm{Cl}$, and ${ }^{2} \mathrm{H}$, and is a $\mathrm{Ca}-\mathrm{SO}_{4}$-type. The median age is $9.4 \mathrm{ka} \mathrm{BP}$. The limited depth information indicates a total depth of at least 80 feet for Zone 7 water. Zone 8 (Eastern mountain-front recharge) occurs along the entire eastern mountain front and represents recharge from that source. The water is characterized by relatively low specific conductance, ${ }^{2} \mathrm{H}, \mathrm{Cl}$, and ${ }^{13} \mathrm{C}$, and is a $\mathrm{Ca}-\mathrm{Na}-\mathrm{HCO}_{3}$-type. Elevated concentrations of $\mathrm{SF}_{6}$ were detected in this water and may have been released from fluid inclusions in granitic rock along the eastern mountain front. Eastern mountain front water has a median age of $5.2 \mathrm{ka} \mathrm{BP}$ and may extend to depths of more than 800 feet. Zone 9 (ground-water inflow from the Tijeras fault zone) occurs along the eastern mountain front south of Tijeras Arroyo, and appears to represent water from crystalline rocks along the Tijeras fault zone that has mixed with eastern mountainfront recharge water (Zone 8). Zone 9 water is characterized by elevated specific conductance, ${ }^{2} \mathrm{H}, \mathrm{B},{ }^{13} \mathrm{C}, \mathrm{Cl}, \mathrm{HCO}_{3}$, and $\mathrm{Li}$. The median age is $16.3 \mathrm{ka} \mathrm{BP}$. Zone 10 (recharge from Tijeras Arroyo) occurs in a narrow zone along Tijeras Arroyo and appears to represent recharge from Tijeras Arroyo. This water is characterized by elevated specific conductance, $\mathrm{SO}_{4}, \mathrm{NO}_{3}$, and ${ }^{2} \mathrm{H}$, and is a $\mathrm{Ca}$ $\mathrm{HCO}_{3}$-type water. The median radiocarbon age of waters sampled from Zone 10 was only $3.2 \mathrm{ka} \mathrm{BP}$. Some waters from Zone 10 (and Zone 12) contain ${ }^{3} \mathrm{H}$ and CFCs indicating that these waters contain at least fractions of post-1950 water. Zone 11 (inflow from the northeast basin margin) occurs along the northeast side of the basin and appears to be a mixture of inflow from the Hagan Embayment, mountain-front recharge and intra-basin arroyo recharge. The water is characterized by elevated specific conductance, $\mathrm{Cl}, \mathrm{Ca}, \mathrm{SO}_{4},{ }^{2} \mathrm{H}, \mathrm{Na}$, and ${ }^{13} \mathrm{C}$. The median radiocarbon age is $10.0 \mathrm{ka} \mathrm{BP}$, but appears older nearest the basin margin, suggesting that inflow from the adjacent Hagan Embayment is relatively old water.

\section{Rio Grande Zones}

Zone 12 (recharge from the Rio Grande) occurs parallel to the Rio Grande from about San Felipe in the northern part of the basin to Abo Arroyo in the south. Zone 12 occurs slightly west of the Rio Grande and as much as $12 \mathrm{~km}$ east of the Rio Grande at Albuquerque. The zone is relatively narrow in the extreme northern and southern extents (Figure C-1). The water from Zone 12 contains relatively low ${ }^{2} \mathrm{H}$ content, and low ${ }^{34} \mathrm{~S}_{\text {of }} \mathrm{SO}_{4}, \mathrm{DO}$, and $\mathrm{SO}_{4}$. Zone 12 water is elevated in dissolved $\mathrm{SiO}_{2}$ and $\mathrm{K}$, with $\mathrm{Ca}$ typically elevated relative to $\mathrm{Na}$. The median age is $4.3 \mathrm{ka} \mathrm{BP}$ and Zone 12 waters occur to depths of greater than 1000 feet. Zone 12 water has younger radiocarbon age, lower $\mathrm{pH}$ and $\mathrm{SO}_{4}$, and higher $\mathrm{Ca}$ than water from Zone 3. Zone 3 water occurs under the western third of Zone 12 (Figure C-1). Zone 13 (basin discharge) was recognized in only three samples from the southern part of the basin and is thought to represent an area of convergence of flow lines due to reduction in thickness and lateral extent of the aquifer. Zone 13 water has elevated specific conductance, $\mathrm{SO}_{4}, \mathrm{Cl}, \mathrm{Li}$ and $\mathrm{B}$. The median chloride content is elevated relative to chloride in adjacent zones, possibly indicating upward movement of water from deeper parts of the basin. Zone 13 water has relatively depleted ${ }^{2} \mathrm{H}$ content, and low DO. The median age of Zone 13 water is $17.9 \mathrm{ka} \mathrm{BP}$.

\section{Conclusions}

This study demonstrates that chemical and isotopic data can be used to improve the understanding of the ground-water flow system in the Middle Rio Grande Basin. Sources of water to the basin-fill aquifer were recognized and were shown to delineate ground-water flow paths. Radiocarbon ages were used to determine travel times along flow paths, and to estimate modern and paleorecharge rates to the aquifer. Modern recharge rates estimated from the spatial- and depth-related radiocarbon ages were only 10 percent of the previously used recharge rate for the ground-water flow model $(138,000$ acre-feet per year, Kernodle and others, 1995) for the basin. Recharge rates during the last glacial period were estimated to be at least 6-fold greater than the modern radiocarbon-based recharge rates. This improved understanding of ground-water sources and ages is being used to further refine the ground-water flow model (Sanford and others, 2000).

\section{References}

Kernodle, J.M., McAda, D.P., and Thorn, C.R., 1995, Simulation of groundwater flow in the Albuquerque Basin, Central New Mexico, 19011994, with projections to 2020: U.S. Geological Survey WaterResources Investigations Report 94-4251, 114p.

Sanford, W.E., Plummer, L.N., McAda, D.P., Bexfield, L.M., and Anderholm, S.K., 2000, Estimation of hydrologic parameters for the groundwater model of the Middle Rio Grande Basin using carbon-14 and water-level data. This volume. 


\title{
D. Regional Stratigraphic Framework for an Integrated Three- dimensional Geologic Model of the Rio Grande Rift
}

\author{
Byron D. Stone ${ }^{1}$, James C. Cole ${ }^{2}$, and David A. Sawyer ${ }^{2}$ \\ ${ }^{1}$ U.S. Geological Survey, National Center, MS 926-A, Reston VA 20192 \\ ${ }^{2}$ U.S. Geological Survey, MS 913, P.O. Box 25046, Denver CO 80225-0046
}

\section{Introduction}

The three-dimensional geologic model of the Middle Rio Grande basin (Cole, 2000) is a general synthesis of the rift-fill deposits of the Neogene Santa Fe Group and younger, erosionally inset fluvial deposits. The stratigraphic framework used in the model (Table D-1) is based on: 1) outcrop geology from new detailed geologic maps; 2) subsurface correlations of geophysical characteristics and samples of units among deep hydrocarbon test wells and shallow water wells; 3 ) seismic reflection profiles; and 4) chronologic control from fossils, tephrochronology, and isotopic dating.

\section{Regional Scale of Model Units}

The digital geologic model uses model horizons that represent the top surface of major lithostratigraphic units (Table D-1), which may be either depositional or erosional. In the mathematical terminology of the model, the term unit designates lithostratigraphic bodies bounded above and below by horizons that are traceable in the subsurface across parts of the subbasins. These units are proposed nominally as formation- and member-rank units in the developing stratigraphic nomenclature of the basins (see examples in Pazzaglia and Lucas, 1999). Model units were defined by the scale of the Middle Rio Grande basin and by the sensitivity of the regional ground-water flow model (McAda and Barroll, 2000). That is, lower stratigraphic units are lumped together, whereas upper units of local extent are split out in order to represent contrasting hydrogeologic characteristics where hydrologic calibration data from wells exist.

The model describes the distribution and thickness of stratigraphic units in each of the Santo Domingo, Calabacillas, and Belen subbasins (Grauch and others, 1999, 2000), and reflects the differences and variabilities among subbasins (Table D-1). In each subbasin, the model establishes an internally consistent three-dimensional geometry of all units. Trends of geologic features within and among units, such as grain-size, composition, paleocurrent directions, and growth-fault relations, reflect geologic processes active through time and thus embody the conceptual framework of the model. Recent studies have refined the estimated ages of various lithostratigraphic units, thus improving time correlations of lithic units among the subbasins. Replicate ages based on different techniques confirm the ages and correlations of several units. Selected age controls are described below only briefly, based on summaries by Kelley (1977), Lozinsky and Tedford (1991), Chapin and Cather (1994), Hawley (1996), Smith and Kuhle (1998), Connell and others (1999), Maldonado and others (1999), and Tedford and Barghoorn (1999).

\section{Framework of the Santo Domingo Subbasin}

Stratigraphic units in the Santo Domingo basin include volcaniclastic deposits (Abiquiu, Keres, and Cochiti units) that are based on the original stratigraphy of Smith and others (1970) in the northern part of the basin. Interbedded within these units are eolian and fluvial deposits that are continuous in the southern and western parts of the basin with lower deposits in the Calabacillas subbasin. Stratigraphic relations among these contrasting deposits are speculative because no deep drill holes have penetrated this area. The Keres and Abiquiu units contain fine and coarse tuffs and sandy conglomerates in the lower part of the sequence. The Cochiti unit is a coarse-grained assemblage of sandy gravel and sand, and lies on the $7 \mathrm{Ma}$ Peralta Tuff at its base, and is overlain by 1.6 Ma Bandelier Tuff near its top. The Chamisa Mesa and Cerro Conejo units extend into the western part of the Santo Domingo basin across the Ziana horst (structural bench). These latter units and part of the Arroyo Ojito unit probably thicken in the subsurface in the central part of the Santo Domingo basin. Piedmont-slope sand and gravel deposits are restricted to areas near the San Francisco fault and in post-Santa Fe alluvial fans. Pebble-cobble channel-gravel deposits (Sierra Ladrones unit), as old as $6.8 \mathrm{Ma}$, are interbedded with volcanics to the north (Smith and Kuhle, 1998); younger gravel deposits cover wide areas of the western and southern (Ceja unit, $<7 \mathrm{Ma}$ ) parts of the subbasin.

\section{Framework of the Calabacillas Subbasin}

Stratigraphic units in the Calabacillas subbasin reflect and build on the original four-fold sequence (lower gray, middle red, and upper buff members of the Santa Fe formation, caliche gravel of the upper buff) of Bryan and McCann (1937) and Wright (1946), and supporting biostratigraphic analyses (Wood and others, 1941; Galusha, 1966). Lithostratigraphic entities in the lower unit of eolian sand (Piedra Parada, Chamisa Mesa, and Cañada Pilares) contain characteristic sequences of sorted, cross-bedded eolian sand that are mapped at the surface and identifiable across the northern part of the subbasin in geophysical logs. These units contain fossils of late Arikarean to late Hemingfordian age (19-22 Ma to $16 \mathrm{Ma}$ ). The overlying unit (Cerro Conejo) contains sandsilt-red clay fluvial sequences, few eolian sand bodies, late 
Barstovian (12-14 Ma) fossils, and weathered 11-13 Ma ash deposits, and has been mapped across western and northern outcrop belts. The higher sequence of units identified in drill holes (medium sand-silt and clay-medium-coarse sand) is correlated with detailed sections exposed in relatively coarse, proximal fluvial deposits at the northern edge of the subbasin (Arroyo Ojito unit). A 6.8 Ma volcanic ash near the top indicates the age of the unit is late Miocene and older. This upper sequence contains a laterally extensive silt and clay (Atrisco) unit in the eastern part of the subbasin that has been correlated among various water wells from drill-hole data (Allen and others, 1998). The overlying sand and gravel (Ceja) unit consists of a lower sand, with local pebblecobble gravel that contains Blancan fossils, and an upper cobble gravel that forms a continuous sheet deposit across the basin to the incised Pleistocene inner valley of the Rio Grande. Equivalent coarse-grained Rio Grande channel deposits merge eastward with piedmont deposits at the foot of the Sandia Mountains.

Fluvial sand and gravel deposits of the "ancestral" Rio Grande that contain clasts of early Quaternary Bandelier Tuff (1.6 $\mathrm{Ma}$ and 1.2 Ma) and Irvingtonian fossils have only been mapped in a narrow band on the east side of the modern river. The position of these deposits and their distinctive clast assemblage suggest they are inset into Santa Fe Group along the inner valley. Younger piedmont and alluvial terrace deposits of middle and late Quaternary age, and Holocene floodplain and arroyo deposits make up the fill of the inner valley.

\section{Framework of the Belen Subbasin}

Stratigraphic units in the Belen subbasin are poorly known because outcrop is sparse and the number of wells is limited. They include basal piedmont-slope deposits around the basin margins near Ladron Peak and along the eastern mountain front. An isolated locality at the foot of the Manzano Mountains exposes a basalt flow (21 Ma; Lozinsky, 1988) interbedded with coarse fluvial conglomerate (abundant rhyolite clasts) that demonstrates a robust fluvial system was draining the volcanic Mogollon highlands to the southwest by early Miocene time.

Overlying closed-basin and through-flowing fluvial deposits of the Santa Fe Group are conceptually subdivided from the initial succession (Popotosa-Santa Fe formation) defined by Denny (1940) according to apparent regional trends in sediment coarseness (Lozinsky, 1988). In the western part of basin, the lower Popotosa unit consists of fine sand and clay, which coarsens upward to coarse sand with scattered gravel at the top. The overlying middle Popotosa contains sand and conglomeratic sand with clay and silt interbeds. The upper Popotosa contains clay beds with sand interbeds in the lower part, which is succeeded by fine to coarse, pebbly sand, in the upper part. In the Shell Isleta Central 1 drill hole in the more distal northeastern part of subbasin, basal claystone and overlying gypsum and sand pass upward into fine and medium sand (lower Popotosa unit). Overlying clay and silt, $2069 \mathrm{ft}$ thick, identified by high gamma-log values, may represent playa lakebeds (middle Popotosa unit). The top part of the drill hole $(0-1280 \mathrm{ft})$ coarsens from silt and clay at the base to coarse sand at the top (upper Popotosa). Sand and gravel of the Sierra Ladrones unit unconformably overlie the Popotosa and consist of a lower sandy part and an upper sand and pebble-to-boulder gravel. Dates of 4.5 Ma from basalt in the lower part of the Sierra Ladrones unit (Machette, 1978), and 2.68 Ma from basalt in the upper gravel indicate a Pliocene age. Terrace and flood-plain alluvium are confined to the Rio Grande and Rio Puerco valleys

\section{Gaps in the Sedimentary Record}

The thickness of Santa Fe Group rift-fill sediments increases from outcrop sections (as little as 1,400 ft thick; Tedford and Barghoorn, 1999) in the Calabacillas subbasin to more than $14,000 \mathrm{ft}$ in fault-bounded depocenters in each subbasin. In exposed parts of the Belen and Santo Domingo subbasins, angular unconformities within the Santa Fe Group indicate breaks in the stratigraphic record related to deformation and erosion (Lozinsky and Tedford, 1994; Cather and others, 1994). In the Calabacillas subbasin, recent studies based on bio- and magnetostratigraphy have identified diastems at the conformable upper and lower boundaries of the Cerro Conejo unit (Tedford and Barghoorn, 1999). These and other missing-time zones identified at the basin margins probably correspond to zones of continuous deposition toward the basin centers. Sporadic fault offsets within the Rio Grande rift provided the space that allowed units to thicken on top of subsiding syn-depositonal fault blocks in progressively deeper parts of Calabacillas subbasin.

\section{References}

Allen, B.D., Connell, S.D., Hawley, J.H., and Stone, B.D., 1998, Core drilling provides information about Santa Fe Group aquifer system beneath Albuquerque's West Mesa: New Mexico Geology, vol. 20, no. 1, p. 813.

Bryan, K., and McCann, F.T., 1937, The Ceja del Rio Puerco--- a border feature of the Basin and Range province in New Mexico; Part 1, stratigraphy and structure: Journal of Geology, v. 45, p. 801-828.

Cather, S.M., Chamberlin, R.M., Chapin, C.E., and McIntosh, W.C., 1994, Stratigraphic consequences of episodic extension in the Lemitar Mountains, central Rio Grande rift, in Keller, R.G., and Cather, S.M., eds., Basins of the Rio Grande rift: Structure, stratigraphy, and tectonic setting: Geological Society of America Special Paper 291, p. 157-170.

Chapin, C.E., and Cather, S.M., 1994, Tectonic setting of the axial basins of the northern and central Rio Grande rift, in Keller, R.G., and Cather, S.M., eds., Basins of the Rio Grande rift: Structure, stratigraphy, and tectonic setting: Geological Society of America Special Paper 291, p. $5-25$.

Cole, J.C., 2000, 3-D geologic modeling of principal regional hydrostratigraphic units in the Albuquerque segment of the Rio grande rift. This volume.

Connell, S.D., Koning, D.J., and Cather, S.M., 1999, Revisions to the stratigraphic nomenclature of the Santa Fe Group, northwestern Albuquerque basin, New Mexico, in Pazzaglia, F.J., and Lucas, S.G. eds., Albuquerque Geology: New Mexico Geological Society Fiftieth Annual Field Conference Guidebook, p. 337-354.

Denny, C.S., 1940, Tertiary geology of the Sand Acacia area, New Mexico: Journal of Geology, v. 48, p. 73-106. 
Galusha, T., 1966, The Zia Sand Formation, new early to medial Miocene beds in New Mexico: American Museum Novitiates, no. 2271, 12 p.

Grauch, V.J.S., Gillespie, C., and Keller, G.R., 1999, Discussion of new gravity maps for the Albuquerque basin area, in Pazzaglia, F.J., and Lucas, S.G. eds., 1999, Albuquerque Geology: New Mexico Geological Society Fiftieth Annual Field Conference Guidebook, p. 119-124.

Grauch, V.J.S., Sawyer, D.A., Keller, G.R., and Gillespie, C.L., 2000, Contributions of gravity and aeromagnetic studies to improving the understanding of subsurface hydrogeology, Middle Rio Grande Basin, New Mexico. This volume.

Hawley, J.W., 1996, Hydrogeologic framework of potential recharge areas in the Albuquerque Basin, central New Mexico, in Hawley, J.W. and Whitworth, T.M., compilers, Hydrogeology of potential recharge areas and hydrogeochemical modeling of proposed aquifer recharge methods in basin- and valley-fill aquifer systems, Albuquerque Basin, New Mexico: New Mexico Bureau of Mines and Mineral Resources Open-file Report 402-D, p. 1-71.

Kelley, V.C., 1977, Geology of the Albuquerque basin, New Mexico: New Mexico Bureau of Mines and Mineral Resources Memoir 33, $60 \mathrm{p}$.

Lozinsky, R.P., 1988, Stratigraphy, sedimentology, and sand petrology of the Santa Fe Group and pre-Santa Fe Tertiary deposits in the Albuquerque Basin, central new Mexico [Ph.D. dissertation]: Socorro, New Mexico, New Mexico Institute of Mining and Technology, $298 \mathrm{p}$.

Lozinsky, R.P., and Tedford, R.H., 1991, Geology and paleontology of the Santa Fe Group, southwestern Albuquerque basin, Valencia County, New Mexico: New Mexico Bureau of Mines and Mineral Resources Bulletin 132, $35 \mathrm{p}$.

Lucas, S.G., Williamson, T.E., and Sobus, J., 1993, Plio-Pleistocene stratigraphy, paleoecology, and mammalian biochronology, Tijeras
Arroyo, Albuquerque area, New Mexico: New Mexico Geology, v. 15, p. 1-8.

McAda, D.P., and Barroll, P., 2000, Revision of the Ground-Water-Flow Model of the Middle Rio Grande Basin, New Mexico. This volume.

Maldonado, F., Connell, S.D., Love, D.W., Grauch, V.J.S., Slate, J.L., Mclntosh, W.C., Jackson, P.B., and Byers, F.M., Jr., 1999, Neogene geology of the Isleta Reservation and vicinity, Albuquerque basin, New Mexico, in Pazzaglia, F.J., and Lucas, S.G. eds., Albuquerque Geology: New Mexico Geological Society Fiftieth Annual Field Conference Guidebook, p. 175-188.

Pazzaglia, F.J., and Lucas, S.G., eds., 1999, Albuquerque Geology: New Mexico Geological Society Fiftieth Annual Field Conference Guidebook, $448 \mathrm{p}$.

Tedford, R.H., and Barghoorn, S., 1999, Santa Fe (Neogene), Ceja del Rio Puerco, northwestern Albuquerque basin, Sandoval County, New Mexico, in Pazzaglia, F.J., and Lucas, S.G., eds., Albuquerque Geology: New Mexico Geological Society Fiftieth Annual Field Conference Guidebook, p. 327-335.

Smith, G.S., and Kuhle, A.J., 1998, Hydrostratigraphic implications of new geologic mapping in the Santo Domingo basin, New Mexico: New Mexico Geology, v. 20, p. 21-27.

Smith, R.L., Bailey, R.A., and Ross, C.S., 1970, Geologic map of the Jemez Mountains, New Mexico: U.S. Geological Survey Miscellaneous Investigations Map I-571, scale 1:125,000.

Wright, H.E., 1946, Tertiary and Quaternary geology of the lower Rio Puerco area, New Mexico: Geological Society of America Bulletin, v. 57, p. 383-456.

Wood, H.E., $2^{\text {nd }}$, and others, 1941, Nomenclature and correlation of the North American continental Tertiary: Geological Society of America Bulletin, v. 52, no. 1, p 1-48.

Table D-1. Model units, lithologic character, and informal lithostratigraphic units used in the preliminary three-dimensional geologic model of the Middle Rio Grande Basin (Cole, 2000)

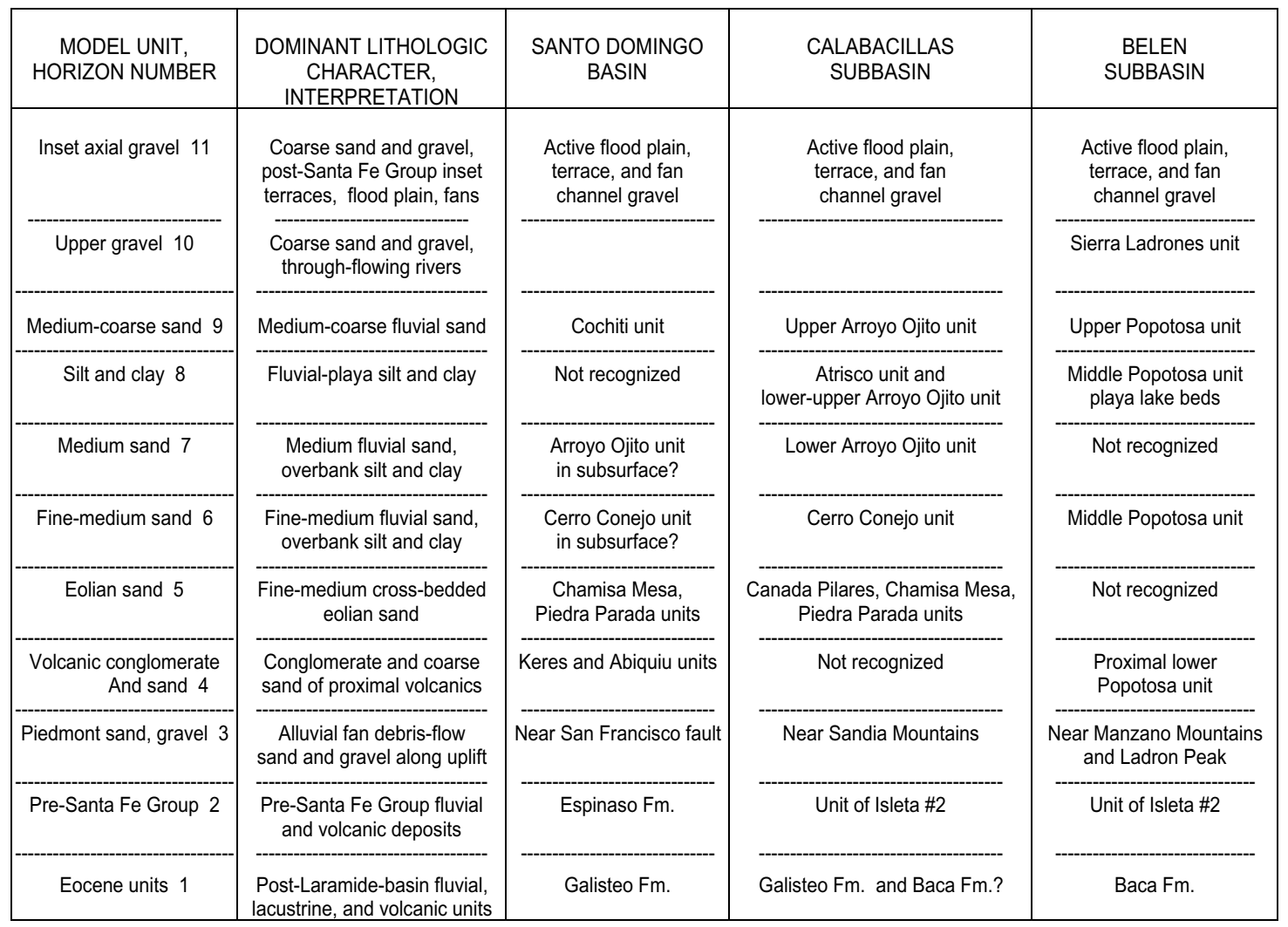




\title{
E. Sedimentary, Stratigraphic, and Hydrologic Consequences of Syn-depositional Faulting in the Rio Grande Rift
}

\author{
Byron D. Stone \\ U.S. Geological Survey, National Center, MS 926-A, Reston VA 20192
}

\section{Introduction}

The effects of syn-depositonal growth faults on offset stratigraphic sequences in the Rio Grande rift basins have been mapped and characterized in exposed eolian-fluvial deposits (Leininger, 1982) and prograding alluvial-fan deposits (Cather and others, 1994). Recent analyses of subsurface data from the Albuquerque basin allow us to analyze growth-fault relations for similar models and for detailed cross-sections at depth. Such syn-depositional fault models are evaluated against the surface geologic relations and against reasonable sedimentation rates for the strata involved. Surface and near-surface normal faults have been documented in detail during this project by basin-wide mapping in outcrops and by high-resolution geophysical surveys (Grauch and others, 2000). These faults offset strata in all parts of the Santa Fe Group in the Santo Domingo, Calabacillas, and Belen sub-basins of the Albuquerque basin (Hudson and others, 1999; Personius and others, 1999; Minor and Hudson, 2000). Most faults are barriers to ground-water flow because they truncate aquifer zones, they contain smeared silt-clay linings along fault planes, or they contain extensive cemented zones (see examples in Haneberg and others, 1999).

\section{Fault Effects on Sedimentation}

Growth faults also control ground-water flow indirectly by their penecontemporaneous forcing of the distribution of fineand coarse-grained facies in fault-bounded local basins. Drainage patterns, gradients, and the distribution of fluvial depositional environments were impacted by active faulting during sedimentation. In the upper part of the Santa Fe Group, growth faults juxtapose coarse- and fine-grained deposits whose textures control their magnetic, electrical resistivity, and gamma radiation characteristics (Hawley and Haase, 1992, Stone and others, 1998, Hudson and others, 1998). These characteristics viewed in plan and vertical sections allow us to trace the continuity and variation in thickness of lithostratigraphic units across the upper parts of these sub-basins (Connell and others, 1998; Rodriguez and others, 2000). Variations in unit lithic characteristics, depositional facies, and thickness across normal faults indicate syn-depositional faulting and response of sedimentary processes to faulting. In particular, thickening of stratigraphic units in local fault-block hanging-wall basins must be accounted for in construction of cross-sections even in areas not characterized by angular unconformities or foot-wall erosion (such as Cather and others, 1994, figs. 4 and 5).

\section{Examples from the Middle Rio Grande Basin}

Syn-depositional fault control of sedimentary sequences is expressed in strata of various ages at a variety of scales in numerous localities around the basin:

- In the Ceja del Rio Puerco outcrop belt at the western mar gin of the Albuquerque basin, Wright (1946) measured 146 feet of wind-blown sand, stream sediments, and colluvium, containing 20 buried caliche soil horizons. These materials accumulated on the footwall block during repeated faulting on the east branch of the Sand Hill fault (Calabacillas fault of Minor and Hudson, 1999).

- Sand and fine gravel beds of the Loma Barbon member of the Arroyo Ojito formation of Connell and others (1999) are mapped across the Zia fault in the northwest part of the Albuquerque basin. Map relations show these beds are about 18 percent thicker in the eastern hangingwall of this syn-depositional fault, based on the projected planar basal contact of the overlying Ceja Member (Connell and others, 1999, fig. 2).

- Modeled and contoured data from the high-resolution airborne electromagnetic survey of Rio Rancho show differences in sediment type across linear boundaries that coincide with faults detected by magnetic surveys. These faults mark boundaries between high resistivity units of sand and gravel (hangingwall) and fine sand-silt-clay units (footwall) in the upper 100-400 $\mathrm{m}$ of section (Deszcz-Pan and others, unpub. data)

- At the southern edge of the Santo Domingo basin, Connell and others (1998) mapped a distinctive facies of colluvial deposits that contrast with equivalent fluvial beds of the Arroyo Ojito formation of Connell and others (1999). The colluvial deposits form a westward-thickening wedge against the Luce fault. Beds thicken from less than $10 \mathrm{ft}$ to about $50 \mathrm{ft}$ near the fault.

- In the eastern part of the Calabacillas subbasin (fig. E-1), multiple wells in syn-depositional fault block basins demonstrate 50 percent thickening of the silt-clay-rich Atrisco beds in the hanging-wall block that contains the College well field.

- In the northern part of the Calabacillas subbasin, the Santa Fe Group thickens markedly across major fault zones. The Santa Fe section is about $1,780 \mathrm{ft}$ thick at the basin margin (Tedford and Barghoorn, 1999), but thickens to about 5,500 $\mathrm{ft}$ in the Tamara well and the combined Rio Rancho 18 and Shell Santa Fe Pacific 3 wells across the Sand Hill, Calabacillas, and other faults (Personius and others, 1999). Magnetic and electromagnetic surveys reveal the normal faults that bound lower and medial Miocene strata in the Ziana horst, the site of the Santa Fe Pacific 3 well. The Zia Formation of Galusha (1966) thickens 415 percent from the 
marginal outcrop belt to the hangingwall basins west of the horst (Tamara well). The Cerro Conejo unit thickens 125 percent and the Arroyo Ojito formation of Connell and others (1999) thickens 145 percent in the upper part of the section.

\section{Deep Structure of the Rift Basins}

Ancient faults that offset the deepest rift-fill strata, such as those bounding the major blocks in accommodation zones between sub-basins (Ziana horst), coincide with steep gradients of gravity values in geophysical models (Grauch and others, 1999). These faults locally trend northwest, oblique to the younger (chiefly) north-trending faults of the basin, reflecting a different stress regime during early rift formation. Structural projections of stratigraphic units in these older, deepest parts of subbasins indicate that syn-depositional faulting also affected sedimentation in the early rift setting.

\section{Growth-fault Consequences to the 3-D Geologic Model}

At present, the three-dimensional geologic model of the Albuquerque basin (Cole and others, 2000) depicts only the 3-D form and distribution of major hydrostratigraphic units. It does not currently incorporate interpretive facies or internal structural features related to growth-fault sedimentation. These details may be shown schematically on individual cross-sections, based on data from wells and a conceptual framework of laterial facies patterns

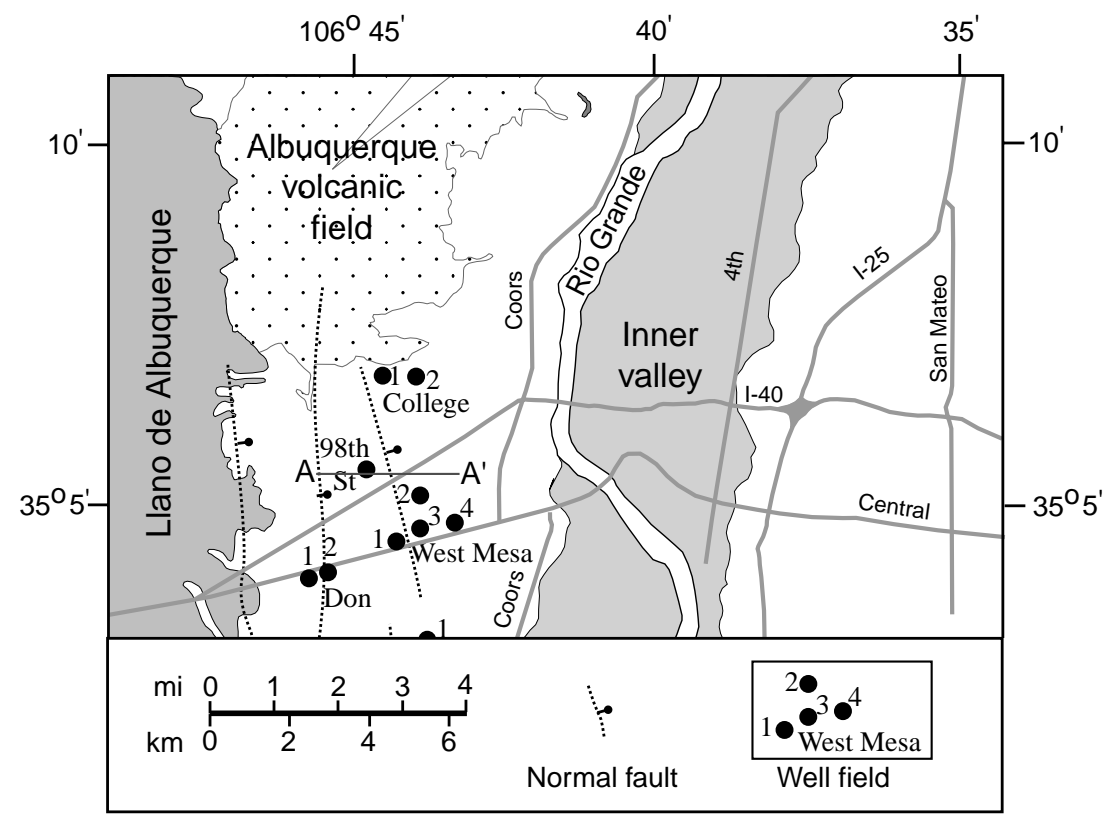

A.

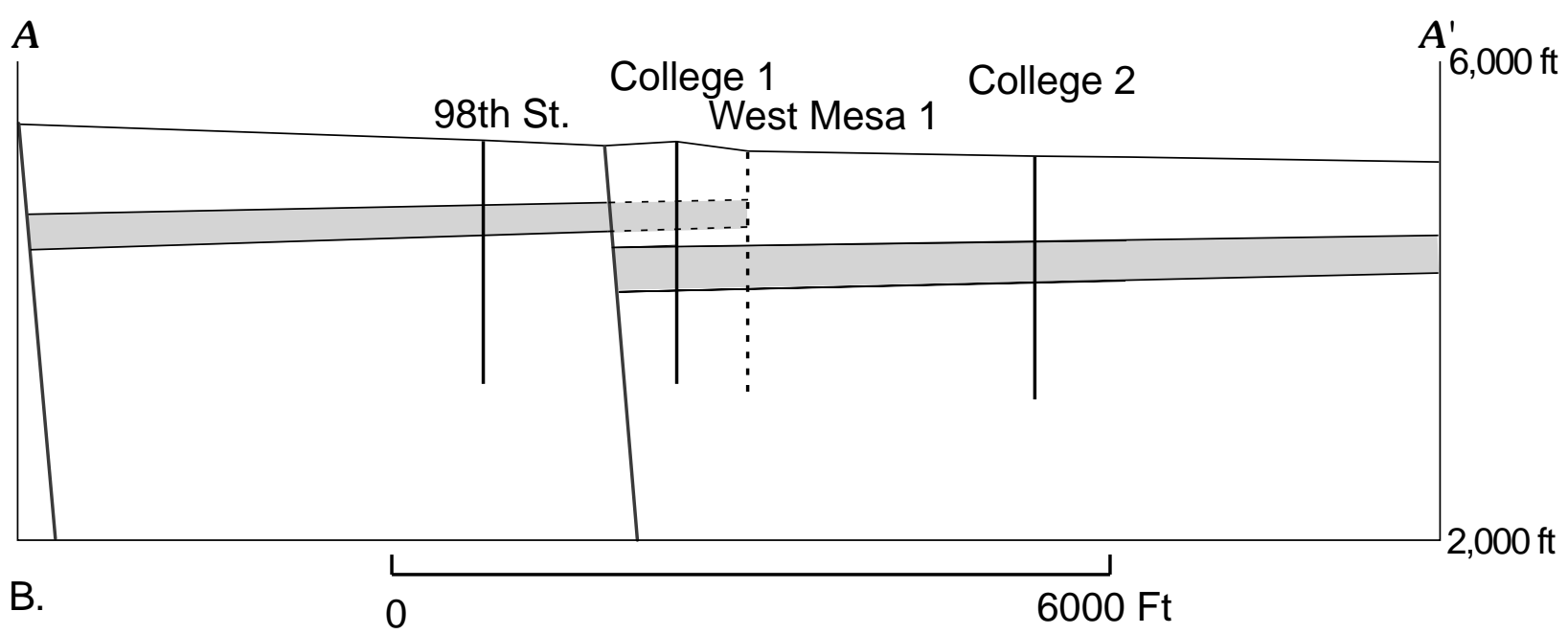

Figure E-1. Syn-depositional fault relations of the Atrisco beds, Albuquerque basin: a)Location of wells and normal faults, b) Cross-section showing thickness and vertical offset of Atrisco beds; projected trace of strata and location of West Mesa \#1 well north of line of section shown by dashed lines, c) Correlation of geophysical logs of the Atrisco beds (in the Arroyo Ojito formation of Connell and others, 1999) in three fault blocks along line $A A^{\prime}$ and extended line to the east; offset on normal faults not shown. 


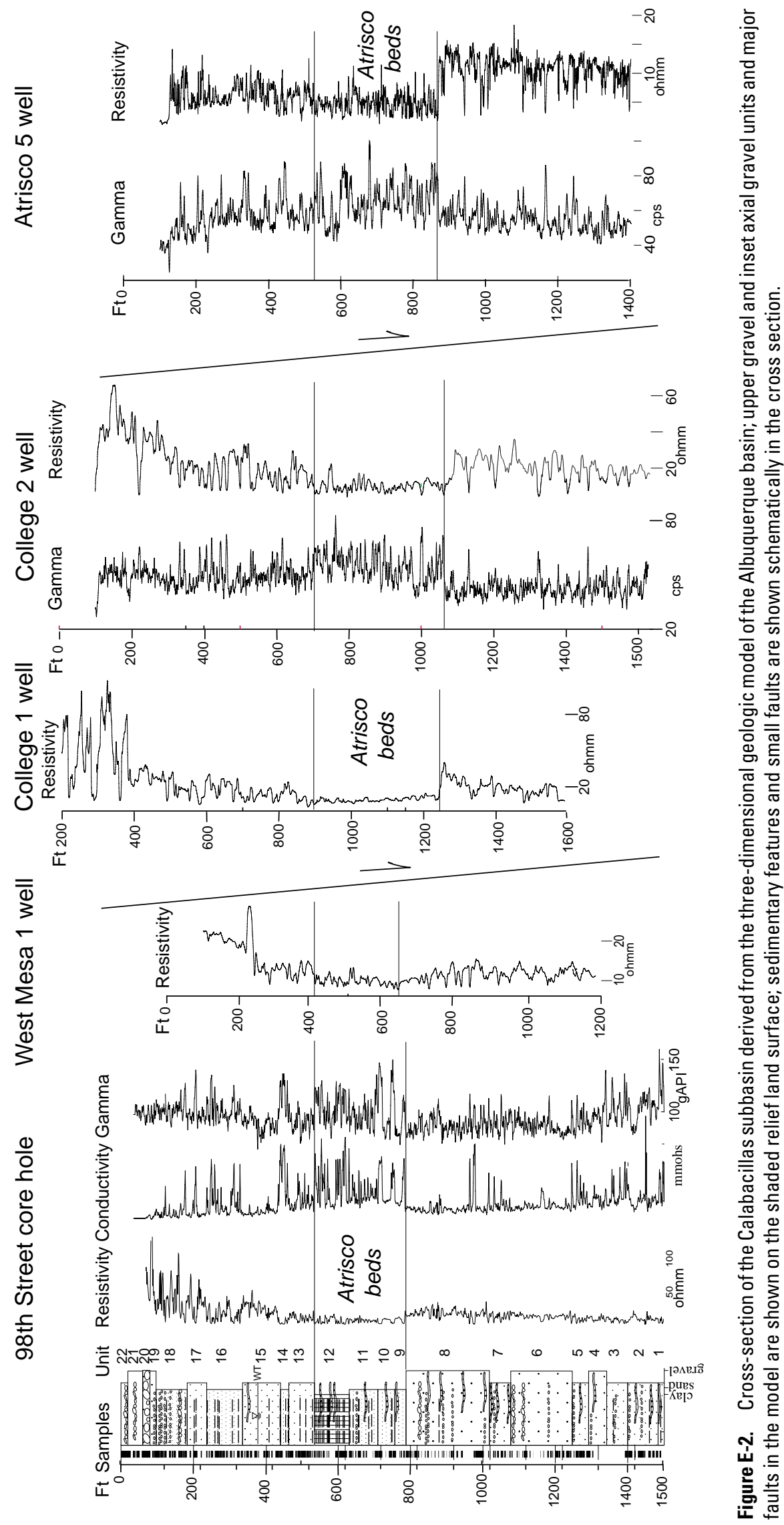


expected in this rift-basin setting (fig. E-2). Several general conclusions can be drawn from these kinds of interpretive sections, from previous sections (Lozinsky and Tedford, 1993; Russell and Snelson, 1994; Hawley, 1996; Connell and others, 1998; Smith and Kuhle, 1998), and from the analysis of lithostratigraphic trends inferred from geophysical logs and outcrops:

- Lithostratigraphic units with contrasting compositional and stratification characteristics, identified from outcrops, drill core, and cuttings samples, can be correlated confidently between outcrop belts and down-hole geophysical logs (particularly natural gamma, conductivity, and resistivity logs).

- No single stratigraphic unit extends continuously across all three subbasins, except the youngest axial-channel facies of the through-flowing Rio Grande.

- Syn-depositional growth-fault scarps controlled local sedimentary environments and depositional patterns of lithofacies in hanging-wall blocks. In some areas, erosion of the footwall block has contributed sediment to the adjacent fault-block basin.

- Lithostratigraphic units inferred from borehole geophysical logs typically change thickness across faults with significant throw. Interpreted cross-sections that project units of constant thickness from fault block to fault block toward the basin depocenters are therefore unrealistic.

- Diastems are recorded between lithostratigraphic units in outcrop belts along basin margins, based on fossil and rockmagnetic data (Tedford and Barghoorn, 1999). Therefore, projection of outcrop units into basin centers based on a simple proportional model of unit thickness is unwarranted and misleading.

- $\quad$ Thickening of units in hanging-wall blocks of growth faults is characteristic of rift-basin sedimentation. Therefore, cross-sections that show strata of constant thickness in each block are inherently unrealistic. The more likely geometric relationship would be depicted by a wedge of strata that thicken toward major faults, and in which bedding dip increases with depth.

\section{References}

Cather, S.M., Chamberlin, R.M., Chapin, C.E., and McIntosh, W.C., 1994, Stratigraphic consequences of episodic extension in the Lemitar Mountains, central Rio Grande rift, in Keller, R.G., and Cather, S.M., eds., Basins of the Rio Grande rift: Structure, stratigraphy, and tectonic setting: Geological Society of America Special Paper 291, p. 157-170.

Cole, J.C, 2000, 3-D geologic modeling of principal regional hydrostratigraphic units in the Albuquerque segment of the Rio Grande rift. This volume .

Connell, S.D., Allen, B.D., and Hawley, J.W., 1998, Subsurface stratigraphy of the Santa Fe Group from borehole geophysical logs, Albuquerque area, New Mexico: New Mexico Geology, v. 20, p. 2-7.

Connell, S.D., Cather, S.M., Ilg, B., Karlstrom, K.E., Menne, B., Picha, M., Andronicus, C., Read, A.S., Bauer, P.W., and Johnson, P.S., 1998, Geology of the Bernalillo and Placitas 7.5-min quadrangle, Sandoval County, New Mexico: New Mexico Bureau of Mines and Mineral Resources Open-file Report OF-DM-2 and OF-DM-16.
Connell, S.D., Koning, D.J., and Cather, S.M., 1999, Revisions to the stratigraphic nomenclature of the Santa Fe Group, northwestern Albuquerque basin, New Mexico, in Pazzaglia, F.J., and Lucas, S.G. eds., Albuquerque Geology: New Mexico Geological Society Fiftieth Annual Field Conference Guidebook, p. 337-354.

Grauch, V.J.S., Gillespie, C.., and Keller, G.R., 1999, Discussion of new gravity maps for the Albuquerque basin area; in Pazzaglia, F.J., and Lucas, S.G. eds., 1999, Albuquerque Geology: New Mexico Geological Society Fiftieth Annual Field Conference Guidebook, p. 119-124.

Grauch, V.J.S., Sawyer, D.A., Keller, G.R., and Gillespie, C.L., 2000, Contributions of gravity and aeromagnetic studies to improving the understanding of subsurface hydrogeology, Middle Rio Grande Basin, New Mexico. This volume.

Haneberg, W.C., Moore, J.C., Mozley, P.S., and Goodwin, L.B., eds., 1999, Faults and subsurface fluid flow in the shallow crust: American Geophysical Union, Geophysical Monograph series, Vol. 113, 222 p.

Hawley, J.W., 1996, Hydrogeologic framework of potential recharge areas in the Albuquerque Basin, central New Mexico, in Hawley, J.W. and Whitworth, T.M., compilers, Hydrogeology of potential recharge areas and hydrogeochemical modeling of proposed aquifer recharge methods in basin- and valley-fill aquifer systems, Albuquerque Basin, New Mexico: New Mexico Bureau of Mines and Mineral Resources Open-file Report 402-D, p. 1-71.

Hawley, J.W., and Haase, C.S., 1992, Hydrogeologic framework of the northern Albuquerque basin: New Mexico Bureau of Mines and Mineral Resources Open-file Report 387, variously paged.

Hudson, M.R., Mikolas, M., Geissman, J.W., and Allen, B.D., 1998, Magnetic properties of Santa Fe Group sediments in the $98^{\text {th }}$ Street corehole, Albuquerque, New Mexico: U.S. Geological Survey Open-File Report 98-592, $71 \mathrm{p}$.

Hudson, M.R., Minor, S.A., Grauch, V.J.S., and Personius, S.F., 1999, Preliminary Characterization of faults in the Middle Rio Grande basin; in Bartolino, J.R., ed., U.S. Geological Survey Middle Rio Grande basin study--Proceedings of the third annual workshop, Albuquerque, New Mexico, February 24-25, 1999: U.S. Geological Survey Open-File Report 99-203, $95 \mathrm{p}$.

Leininger, R.L., 1982, Cenozoic evolution of the southernmost Taos Plateau, New Mexico; unpublished M.S. Thesis, University of Texas at Austin, $110 \mathrm{p}$.

McAda, D.P., and Barroll, P., 2000, Revision of the Ground-Water-Flow Model of the Middle Rio Grande Basin, New Mexico. This volume.

Minor, S.A., and Hudson, M.R., 2000, Structural and physical properties and cementation patterns of fault zones in the northern Albuquerque basin, New Mexico: implications for ground-water flow: U.S. Geological Survey Bulletin [in press, 2000], $43 \mathrm{~ms}$ p.

Personius, S.F., Machette, M.M., and Stone, B.D., 2000, Preliminary geologic map of the Loma Machete quadrangle, Sandoval County, New Mexico: U.S. Geological Survey Miscellaneous Field Investigations Map MF-2334, scale 1:24,000

Rodriguez, B.D., Cole, J.C., Grauch, V.J.S., Sawyer, D.A., Stone, B.D., and Thompson, R.A., 2000, Subsurface geology of the Albuquerque volcanoes and Llano de Albuquerque area, New Mexico, based on geologic mapping, airborne and ground geophysics, and limited subsurface information. This volume.

Russell, L.R., and Snelson, S., 1994, Structure and tectonics of the Albuquerque Basin segment of the Rio Grande Rift-Insights from reflection seismic data, in Keller, R.G., and Cather, S.M., eds., Basins of the Rio Grande rift: Structure, stratigraphy, and tectonic setting: Geological Society of America Special Paper 291, p. 83-112. 
Smith, G.S., and Kuhle, A.J., 1998, Hydrostratigraphic implications of new geologic mapping in the Santo Domingo basin, New Mexico: New Mexico Geology, v. 20, p. 21-27.

Stone, B.D., Allen, B.D., Mikolas, M., Hawley, J.W., Haneberg, W.C., Johnson, P.S., Allred, B., and Thorn, C.R., 1998, Preliminary lithostratigraphy, interpreted geophysical logs, and hydrogeologic characteristics of the 98th Street core hole, Albuquerque, New Mexico: U.S. Geological Survey Open-File Report 98-210, 82 pp
Tedford, R.H., and Barghoorn, S., 1999, Santa Fe (Neogene), Ceja del Rio Puerco, northwestern Albuquerque basin, Sandoval County, New Mexico, in Pazzaglia, F.J., and Lucas, S.G. eds., 1999, Albuquerque Geology: New Mexico Geological Society Fiftieth Annual Field Conference Guidebook, p. 327-335.

Wright, H.E., 1946, Tertiary and Quaternary geology of the lower Rio Puerco area, New Mexico: Geological Society of America Bulletin, v. 57, p. 383-456.

\title{
F. Is the Top of the upper Santa Fe Group Diachronous in the Albuquerque Basin?
}

\author{
S.D. Connell ${ }^{1}$, D.W., Love ${ }^{1}$, F. Maldonado ${ }^{2}$, P.B. Jackson ${ }^{1}$, W.C. McIntosh ${ }^{1}$, \\ and M.C. Eppes ${ }^{3}$ \\ ${ }^{1}$ New Mexico Bureau of Mines and Mineral Resources, 801 Leroy, Socorro NM 87801 \\ ${ }^{2}$ U.S. Geological Survey, Box 25046, MS 913, Denver CO 80225 \\ ${ }^{3}$ Dept. of Earth and Planetary Sciences, Univ. New Mexico, Albuquerque NM 87131
}

\section{Introduction}

The Santa Fe Group (SFG) constitutes the syn-rift-basin fill of the Albuquerque Basin, New Mexico. Conceptually, SFG deposition is thought to have ceased when the Rio Grande and its tributaries incised into a surface of maximum basin aggradation, during early Pleistocene(?) time (Connell and others, 1999). We suggest that the top of the uppermost SFG in the Albuquerque Basin is diachronous in nature, and that termination of SFG deposition may be recorded on a number of constructional surfaces of contrasting ages. If our suggestion is valid, then differentiation of the SFG from younger deposits requires a better understanding of the temporal and spatial distribution of such surfaces. We interpret the temporal and spatial distributions of such surfaces to be strongly influenced by major intrabasinal faults. Deposits that post-date SFG aggradation may be distinguishable by their position on the landscape relative to known geomorphic surfaces; some young deposits are inset, others may prograde across older surfaces. We discuss new data from four such inferred terminal SFG geomorphic surfaces in the vicinity of Albuquerque and the Isleta Indian Reservation.

\section{Sunport Surface}

The Sunport geomorphic surface (SP) lies about 90-115 m above the Rio Grande. Soils on the SP generally exhibit Stage III to IV carbonate morphology (Machette, 1985) and are commonly formed in eolian deposits that overlie ancestral Rio Grande fluvial deposits. These fluvial beds contain early Pleistocene fossils, transported (upper and lower) Bandelier Tuff clasts, and the 1.2 Ma Tshirege ash (HC-C, PL, Fig. F-1). Projections of the highest (oldest) known (middle Pleistocene) ancestral Rio Grande terrace are about 20-30 m below the level of the SP. Terrace treads to the north, at similar heights above local base level (that is, 70-85 m) in the Rio Grande, Rio Chama, and Rio Jemez valleys, locally overlie the 0.6 Ma Lava Creek B ash (Smith and Kuhle, 1999), as do terrace remnants to the west and south along the Rio Puerco and Rio Grande valleys. This apparently widespread inset terrace relationship suggests to us that the Rio Grande and its tributaries had begun to incise into the upper SFG between 1.2 and $0.6 \mathrm{Ma}$.

\section{Llano de Manzano Surface Complex}

The Llano de Manzano (LdM) geomorphic-surface complex contains at least three locally distinguishable surfaces underlain by piedmont deposits derived from the Manzano Mountains. These deposits prograde over Bandelier-pumicebearing ancestral Rio Grande deposits, and are thus interpreted to be younger than the SP. Soils developed on the LdM generally exhibit Stage III+ to IV carbonate morphology. Intermediateheight constructional piedmont-slope surfaces are locally preserved across the Hubbell Springs fault zone (HC-U, HC-C, Fig. F-1). With the notable exception of major tributaries such as Tijeras Arroyo, Hell Canyon Wash, and Abo Arroyo, nearly all smaller drainages off the Manzano Mountains do not incise the SFG. Instead, sediments from these drainages commonly bury SFG deposits and do not record long-term incision by the Rio Grande. We infer that aggradation and episodic soil formation continued locally on the LdM into the middle Pleistocene. We also infer that aggradation was controlled by the LdM, which acted as a regional base level for most streams draining the Manzano Mountains. We further infer that aggradation was locally influenced by episodic movement along neighboring intrabasinal faults. 
The Cañada Colorada geomorphic surface (CC) is recognized only on the Hubbell bench (HB-S, Fig. F-1), where it forms a high piedmont-slope (about 10-35 m above Cañada Colorada, and about 30-50 $\mathrm{m}$ above local LdM surface). The CC surface is underlain by very thick (2-3 m) calcic soils exhibiting Stage III+ to degraded (eroded) possible Stage V(?) carbonate morphology. Deposits underlying the $\mathrm{CC}$ are well cemented and unconformably overlie Permian and Triassic rocks. Although no age control is known for the $\mathrm{CC}$, the deeply embayed nature of drainages crossing the Hubbell Spring fault zone (sinuosity ratio of $~ 3.7$ ) and very strong soil development suggest that this local top of SFG deposition may have stabilized prior to development of the LdM, perhaps during Pliocene, or possibly late Miocene time.

\section{Llano de Albuquerque Surface}

The Llano de Albuquerque geomorphic-surface complex (LdA) is a gently south-sloping mesa about $110-215 \mathrm{~m}$ above the Rio Grande. We interpret the LdA here to comprise one of the oldest constructional surfaces in the Albuquerque Basin. Soils on the LdA commonly exhibit Stage III+ to IV carbonate morphology and are commonly formed in eolian and fluvial sediments.

The Cat Mesa basalt (3.0 Ma) is overlain by $19 \mathrm{~m}$ of ancestral Rio Puerco sediments that predate the LdA (CM, Fig. F-1; Maldonado and others, 1999). Pliocene fossils are reported at similar stratigraphic intervals beneath the LdA (Morgan and Lucas, 1999). The Tshirege ash (1.2 Ma; Bachman and Mehnert, 1978) is found in slope deposits that were eroded from the 1.2 Ma Los Lunas volcano. These hill-slope deposits at Los Lunas overlie a moderately developed (Stage III) calcic soil formed in ancestral Rio Puerco deposits. We interpret that calcic soil to represent the LdA surface, and so the hill-slope deposits at Los Lunas post-date the LdA. Thus, the LdA and underlying Rio Puerco deposits are older than 1.2 Ma in the study area, and may possibly be pre-Quaternary in age. A pre-1.2 Ma age for the LdA is consistent with our observation that ancestral Rio Grande sediments that contain clasts of the Bandelier Tuff overlie, rather than interfinger with, sediments laid down by the ancestral Rio Puerco east of the LdA at Tijeras Arroyo.

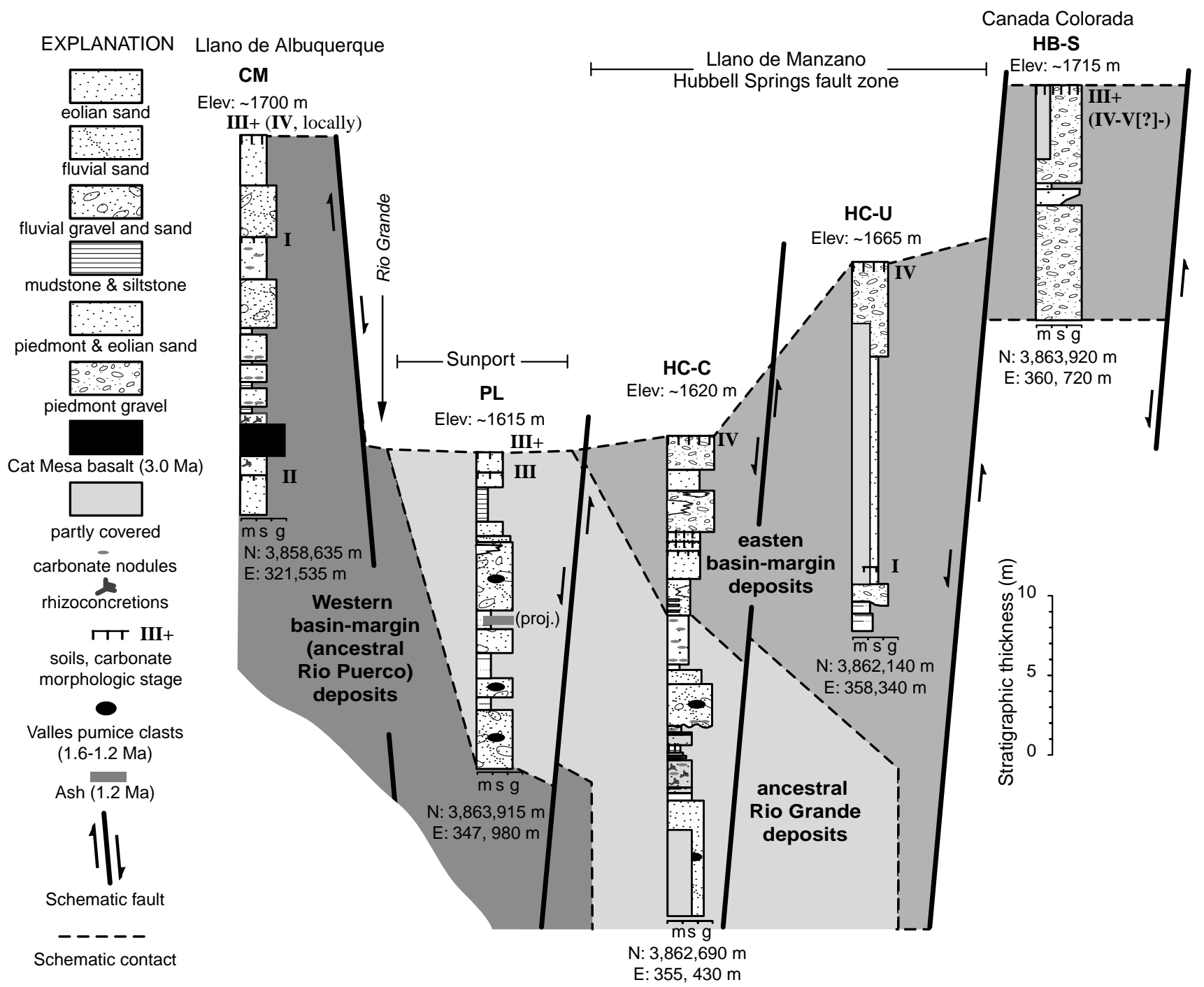

Figure F-1. Schematic stratigraphic sections and altidudes of geomorphic surfaces (in meters above mean sea level) at selected measured sections, illustrating topographic, stratigraphic, soil-morphologic, and age relationships across the Albuquerque Basin on the Isleta Reservation. Roman numerals indicate pedogenic carbonate-morphology stage. Approximate locations of stratigraphic sections are recorded in UTM (NAD 83) coordinates. Fault locations and offsets are shown schematically. 


\section{Implications for Fault History}

Earthquake recurrence intervals for faults that cut these four geomorphic surfaces have been based on estimated ages of calcic soil development (Machette, 1982). Our data suggest that these surfaces are much older than previous age estimates. Thus, intrabasinal faults that cut these surfaces may possibly have lower recurrence rates than previously thought. For example, the LdA was estimated to be $\sim 500 \mathrm{ka}$ (Machette, 1985), but we demonstrate that it is older than 1.2 Ma in the Los Lunas area. The age of the LdM and SP were estimated to be $\sim 320 \mathrm{ka}$ but could be more than twice as old, at least locally. The relatively weak stage of soil development for Pliocene and Pleistocene surfaces such as the LdA may be due to periodic deposition of the rather extensive overlying eolian sand cover and to episodic stripping.

\section{References}

Bachman, G.0., and Mehnert, H.H., 1978, New K-Ar dates and the late Pliocene to Holocene geomorphic history of the central Rio Grande region, New Mexico: Geological Society of America Bulletin, v. 89, p. 283-292.
Connell, S.D., Koning, D.J., and Cather, S.M., 1999, Revisions to the stratigraphic nomenclature of the Santa Fe Group, northwestern Albuquerque basin, New Mexico: New Mexico Geological Society, Guidebook 50, p. 337-353.

Machette, M.N., 1982, Quaternary and Pliocene faults in the La Jencia and southern Albuquerque-Belen basins, New Mexico --- Evidence of fault history from fault-scarp morphology and Quaternary geology: New Mexico Geological Society, Guidebook 33, p. 161-169.

Machette, M.N., 1985, Calcic soils of the southwestern United States; in Weide, D.L., and Faber, M.L., eds., Soil and Quaternary geology of the southwestern United States: Geological Society of America, Special Paper 230, p. 1-42.

Maldonado, Florian, Connell, S.D., Love, D.W., Grauch, V.J.S., Slate, J.L., McIntosh, W.C., Jackson, P.B., and Byers, F.B., Jr., 1999, Neogene geology of the Isleta Reservation and vicinity, Albuquerque basin, New Mexico: New Mexico Geological Society, Guidebook 50, p. 175-188.

Morgan, G.S., and Lucas, S.G., 1999, Pliocene (Blancan) vertebrates from the Albuquerque basin, north-central New Mexico: New Mexico Geological Society, Guidebook 50, p. 363-370.

Smith, G.A., and Kuhle, A.J., 1999, Geologic map of the Santo Domingo Southwest quadrangle, Sandoval County, New Mexico: New Mexico Bureau of Mines and Mineral Resources, Open-File Digital Map OFDM-26, scale 1:24,000.

\title{
G. Subsurface Constraints on the Hydrogeologic Model of the Middle Rio Grande Basin, New Mexico, Using Airborne Time- domain Electromagnetic Data
}

\author{
B.D. Rodriguez ${ }^{1}$, M. Deszcz-Pan ${ }^{1}$, D.A. Sawyer ${ }^{2}$, and B.D. Stone ${ }^{3}$ \\ 'U.S. Geological Survey, MS 964, Box 25046, Denver C0 80225 \\ ${ }^{2}$ U.S. Geological Survey, MS 913, Box 25046, Denver C0 80225 \\ ${ }^{3}$ U.S. Geological Survey, National Center, MS 926A, Reston VA 20192
}

\section{Introduction}

The Santa Fe Group aquifer in the Middle Rio Grande Basin (MRGB) is the main source of municipal water for the greater Albuquerque urban and suburban area. Water in the aquifer is more limited than previously thought (Kernodle and others, 1995). Future growth and land management decisions in the region will rely on accurate assessments for protection of the groundwater resources. Our work provides information about the subsurface distribution of hydrostratigraphic materials to improve the hydrogeologic models of the MRGB, and to provide scientific interpretation to aid land and water managers.

\section{Methods}

Electromagnetic methods examine subsurface resistivity (or its inverse, conductivity). Resistivities of sediments are primarily determined by porosity, pore fluid resistivity, saturation, and the presence of certain electrically conductive minerals, such as clays. Fracture zones and faults that contain clays or water reduce resistivity. Resistivities of unaltered igneous rocks are generally high. To efficiently cover wide areas, airborne methods are used as developed by Geoterrex, Inc. (contractor to USGS for this work). Spatial sampling of the subsurface is determined by line spacing and by sampling rate along the flight lines. Airborne Time-Domain electromagnetic (TEM) data for the Rio Rancho area northwest of Albuquerque (Figure G-1) were collected in 1997 over a $25 \mathrm{~km}$ x $40 \mathrm{~km}$ area using 400-m flight-line spacing at $120 \mathrm{~m}$ above ground level (Deszcz-Pan and others, 1998). Over urban areas, the flight height reached about $250 \mathrm{~m}$ above ground level. Along-line data were collected about 10 to $15 \mathrm{~m}$ apart.

Airborne TEM can be used to infer the general distribution of subsurface resistivity up to depths of several hundred meters. In the Geoterrex GEOTEM system, an antenna mounted on the airplane 


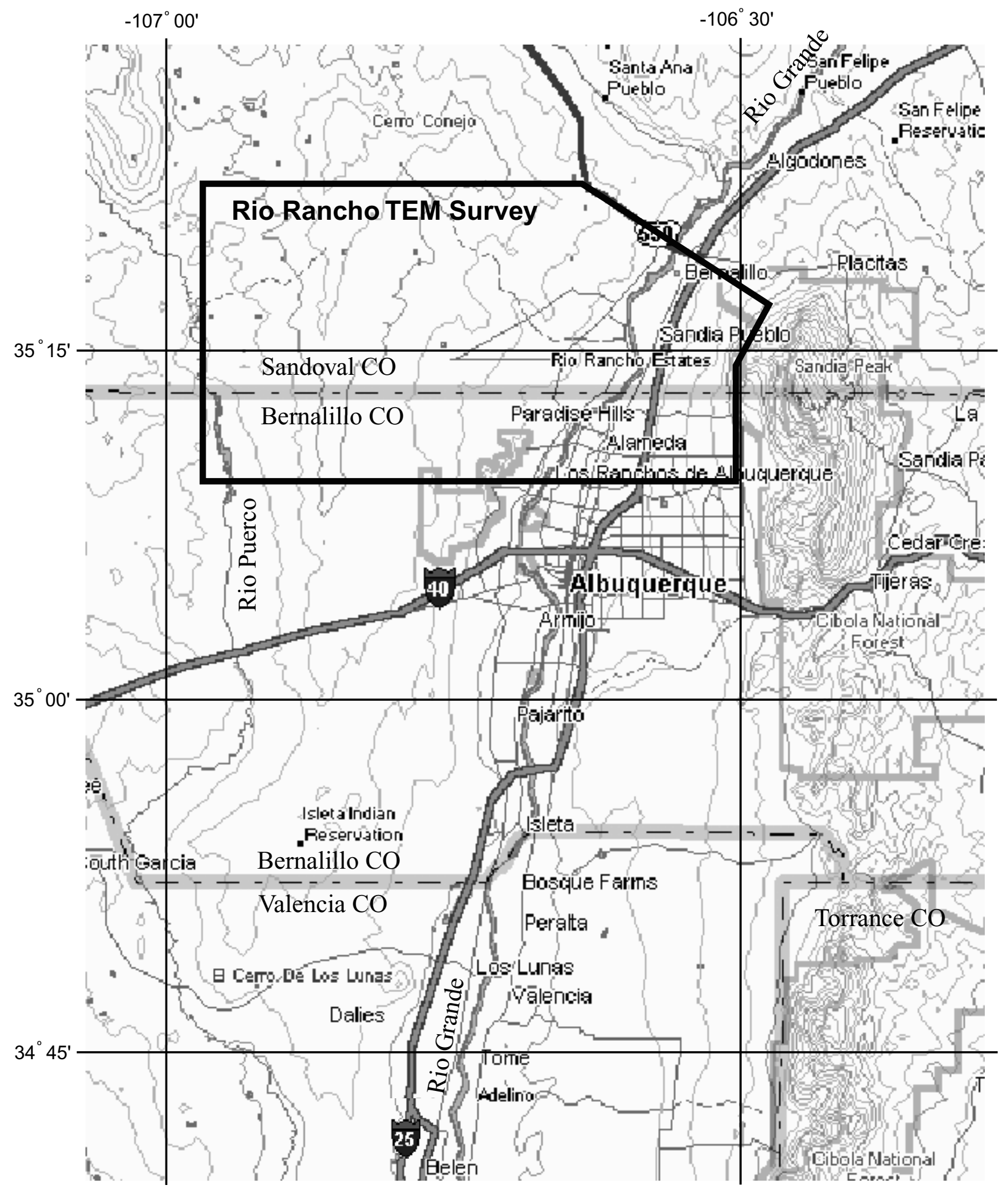

Figure G-1. Airborne Time-Domain Electromagnetic (TEM) Rio Rancho index map in the Middle Rio Grande basin, New Mexico.

generates a burst of EM signal. A receiver towed below and behind the airplane then receives the arriving EM signal as voltage at specific times after each pulse (TEM response). Although the received signal is affected by many factors, the shape and strength of the signal largely reflects the subsurface distribution of resistivity in earth materials. Earlier arrival times provide information on shallower depths, and later arrival times provide information on greater depths. Using appropriate algorithms, measured voltages are then converted to resistivity distribution with depth.

\section{Interpretation}

Conversion of the recorded signal to resistivity is not an unique process and a number of algorithms can be used. Many were developed for geophysical prospecting to locate metallic sulfide deposits, but their use in hydrogeological mapping is still being evaluated. Interpretive techniques to map subtle resistivity variations due to sedimentary facies changes are not fully developed, and inversion of raw data into a credible picture of earth 


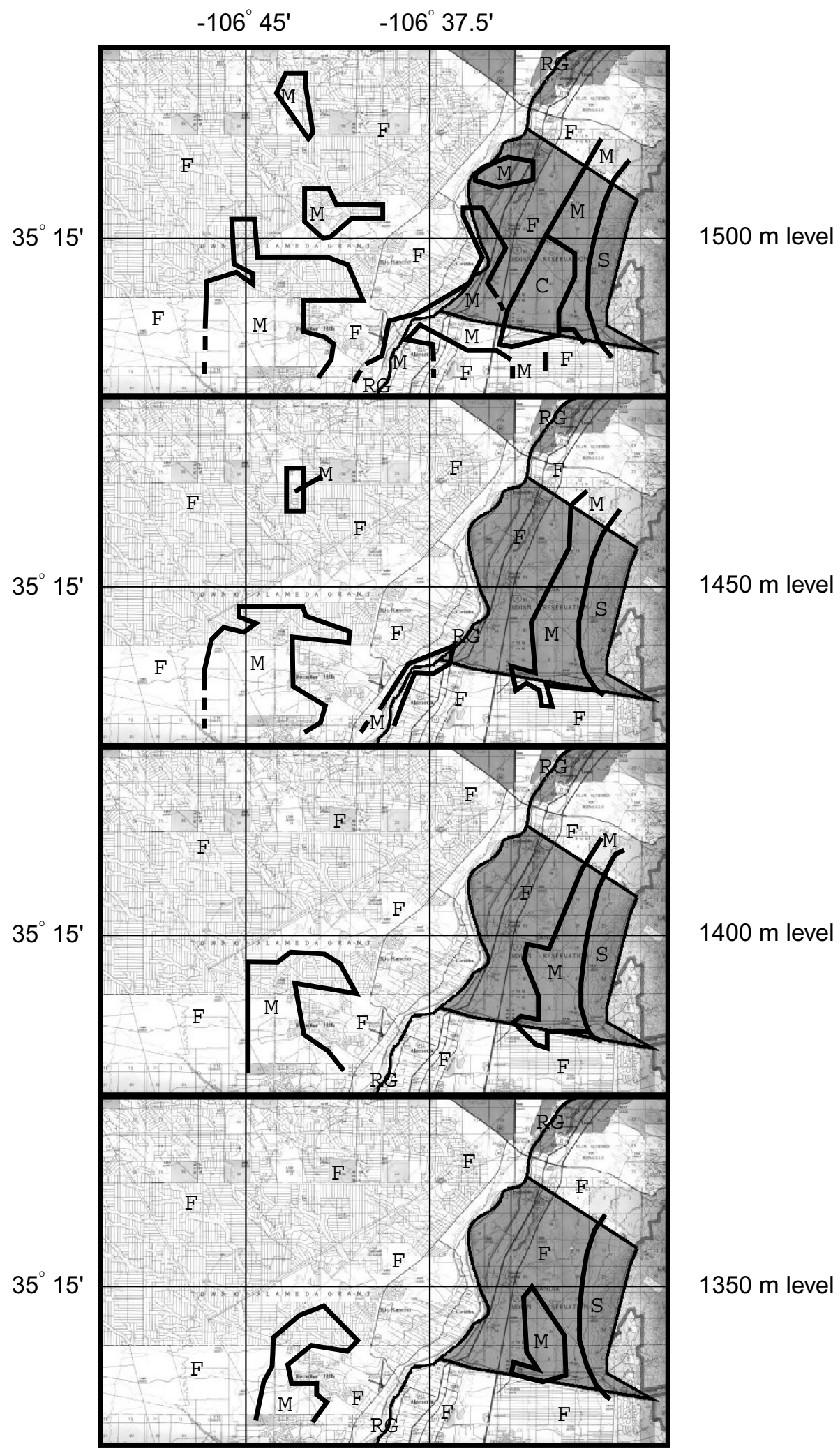

Figure G-2. Resistivity interpretive maps. Symbols refer to inferred subsurface extent of Sandia Mountain front (S), Rio Grande (RG), and sedimentary grain size: Coarse (C), Medium (M), Fine (F). Lowest valley floor elevation in survey area is 1515 meters above sea level and highest elevation of Sandia Mountain front is 2000 meters. 
resistivity with depth requires significant interpretation. Pipelines, communication lines, large fences, railways and other man-made conductors can contribute large TEM responses that complicate interpretation. Most man-made anomalies can be easily identified if the source is large, but diffuse responses from scattered objects can be subtle and mistaken for the earth response. This kind of "noisy" TEM response is severe in the southeast part of the survey, and our interpretations there are more tentative.

We used algorithms developed and owned by BHP geophysical company for the data analysis. They provided resistivity sections that closely correlate with well logs and geological cross-sections. Interpretive maps (Figure G-2) show good correlation between gross patterns and the general distribution of subsurface lithologic units determined from drill-hole information. The average ranges of resistivity in the saturated zone from geophysical logs are known to correlate approximately with sediment grain size as follows: coarse (40-100 ohm-m), medium (20-40 ohm-m), fine (10-20 ohm-m). These resistivity ranges were used to infer likely sediment grain sizes from the TEM interpretations. Outcrop and lithologic well data show that axialriver-channel deposits are composed of coarse-grained sand and gravel facies, floodplain fluvial deposits are composed of medium-grained sand and silt facies, and overbank fluvial deposits are composed of fine-grained silt and clay facies (Connell and others, 1998; Stone and others, 1998).

In the east, high resistivities can be related to ancestral Rio Grande axial-gravel deposits (C in Figure G-2) inferred from well logs. Coarse-grained sediments that exist at $1500 \mathrm{~m}$ above sea level appear to be less than $50 \mathrm{~m}$ thick below the water table (apparently absent at the $1450 \mathrm{~m}$ level). In the north, an area of lower resistivity coincides with uplifted silty units ( $F$ in Figure G-2) of the lowest Santa Fe Group deposits. In the south-central part of the map, higher resistivities correspond in part to middle Santa Fe units that contain numerous channel-sand bodies ( $M$ in Figure G-2). The resistivity pattern suggests this unit does not extend as far north as expected. In the west, shale ( $\mathrm{F}$ in Figure G-2) likely causes the lowest resistivities. At the $1350 \mathrm{~m}$ level, the lateral extent of fluvial sand deposits (M in Figure G-2)

appears to be much reduced.

\section{Summary}

The stitched three-dimensional resistivity model provides a framework for forecasting hydrologic conditions in areas less explored by drilling. Our three-dimensional model provides direct input to ground-water flow models that are critical to water management agencies. This model provides quantitative, testable forecasts of hydrogeologic conditions that stimulate further exploration and model refinement. Future work with this methodology may entail comprehensive lithologic interpretation of borehole geophysical logs and correlation between wells for comparison with modeled resistivity values.

\section{Acknowledgements}

We are very grateful to BHP Minerals for their collaboration in this work. Particular mention is due Robert Ellis (author of the least-squared layered inversion algorithm), Guimin Liu (author of the conductivity depth image algorithm), Michelle Godbout (now with Condor Consulting, Inc., Wheat Ridge CO), and Jon Doucette (now with U.S. Geological Survey, Denver CO) for processing the TEM data and producing the conductivity images shown in our interpretations.

\section{References}

Connell, S.D., Allen, B.D., and Hawley, J.W., 1998, Subsurface stratigraphy of the Santa Fe Group from borehole geophysical logs, Albuquerque area, New Mexico: New Mexico Geology, v. 20, p. 2-7.

Deszcz-Pan, M., Rodriguez, B.D., Grauch, V.J.S., Stone, B.D., Sawyer, D.A., and Labson, V., 1998, Preliminary geophysical results from the Rio Rancho area, New Mexico: in Slate, J.L., ed., U.S. Geological Survey Middle Rio Grande basin study--Proceedings of the Second Annual Workshop, Albuquerque, New Mexico, February 10-11, 1998, U.S. Geological Survey Open File Report 98-337, p. 36-37.

Stone, B.D., Allen, B.D., Mikolas, M., Hawley, J.W., Haneberg, W.C., Johnson, P.S., Allred, B., and Thorn, C.R., 1998, Preliminary lithostratigraphy, interpreted geophysical logs, and hydrogeologic characteristics of the 98th Street core hole, Albuquerque, New Mexico: U.S. Geological Survey Open-File Report 98-210, 82 pp 


\title{
H. Geologic Map of Isleta Reservation and Contiguous Areas, Central New Mexico
}

\author{
Florian Maldonado ${ }^{1}$, Dave W. Love ${ }^{2}$, Sean D. Connell ${ }^{2}$, Janet L. Slate ${ }^{1}$, \\ Karl E. Karlstrom ${ }^{3}$, and Van S. Williams ${ }^{1}$ \\ 1U.S. Geological Survey, MS 913, P.O. Box 25046, Denver C0 80225 \\ ${ }^{2}$ New Mexico Bureau of Mines and Mineral Resources, 801 Leroy, Socorro NM 87801 \\ ${ }^{3}$ Dept. of Earth and Planetary Sciences, Univ. New Mexico, Albuquerque NM 87131
}

\section{Introduction}

The Isleta Reservation straddles the middle of the Albuquerque basin, from the Rio Puerco eastward to the Manzano and Manzanita Mountains, just south of Albuquerque, New Mexico. The U.S. Geological Survey, New Mexico Bureau of Mines and Mineral Resources, and the University of New Mexico have conducted geologic mapping on the Isleta Reservation and vicinity as part of the Middle Rio Grande Basin Project. The study area comprises twelve 7.5-minute quadrangles that have been mapped at 1:24,000 scale and compiled at 1:50,000 scale. This geologic mapping has enhanced our understanding of the stratigraphy, structure, and geomorphic evolution of the middle Albuquerque basin.

\section{Rocks Older than the Santa Fe Group}

Pre-Santa Fe Group rocks exposed in the map area include Proterozoic metamorphic and plutonic rocks and upper Paleozoic and Mesozoic strata. Proterozoic crystalline rocks exposed in the Manzano and Manzanita Mountains consist of greenstone, metarhyolite, and pelitic and quartzofeldspathic schist intruded by granite and diorite-gabbro. A prominent unconformity along the mountain crest is capped by siliciclastic units of the Pennsylvanian Sandia Formation and Madera Group. Pennsylvanian through Triassic rocks (Madera, Abo, Yeso, Glorieta, San Andres, Moenkopi, and Chinle Formations) are discontinuously exposed in eroded Cenozoic footwall blocks between the Coyote fault and the Hubbell Spring fault zone. These rocks were strongly faulted and folded, probably during Laramide deformation. East-dipping Crevasse Canyon Formation (Upper Cretaceous) is exposed along the western margin of the study area. Paleogene rocks are not exposed in the study area, but are as much as $2 \mathrm{~km}$ thick in the subsurface (Lozinsky, 1994).

\section{Rocks of the Santa Fe Group}

The Santa Fe Group is informally described as lower and upper units. The lower part of the Santa Fe Group is only exposed near the southwestern corner of the study area in the footwall of the Mohinas Mountain fault. These deposits consist of reddish-brown mudstone and sandstone identified by
Lozinsky and Tedford (1991) as the Popotosa Formation. They interpreted deposition of these sediments in a basin-floor playa setting. Just west of the southwest corner of the map area, trough-cross-bedded fluvial sandstone is interbedded with a lower, older part of the Popotosa, which predates intrusion by the diabase of Mohinas Mountain at 8.3 Ma (Baldridge and others, 1987). The Popotosa Formation is faulted to the east against deposits of the informal upper Santa Fe Group.

We recognize three major facies within the informal upper Santa Fe Group deposits. A western-margin facies of mostly fine sediment is derived from major tributary fluvial systems (ancestral Rio Puerco) that drained the adjacent Colorado Plateau and Sierra Nacimiento to the west and north. A centralbasin facies contains deposits of the ancestral Rio Grande axialfluvial system. The eastern-margin facies consists mostly of alluvial slope deposits shed from the eastern rift-border uplifts of the southern Sandia Mountains, Manzanita Mountains, and Manzano Mountains.

Basalt eruption has accompanied deposition of upper Santa Fe Group fluvial and eolian sediments in the central and western parts of the rift through Neogene time. Six eruptive centers have been active at various intervals (Maldonado and others, 1999): Black Mesa (2.68 Ma); Isleta (2.73 Ma to 2.79 Ma); Cat Mesa (3 Ma), Los Lunas (3.91 Ma older flows), Wind Mesa (4 Ma), and El Cerro Tome (3.4 Ma; Bachman and Mehnert, 1978). All of these flows interfinger with western basin-margin deposits. Stratigraphic relationships at El Cerro Tome are ambiguous, but the basalts here are probably overlain by fluvial deposits of the central basin facies.

Geologic mapping, stratigraphic studies, and carbonate-soil data indicate the top of the Santa Fe Group is defined by at least four diachronous aggradational surfaces (Connell and others, this volume).

\section{Units Younger Than Santa Fe Group}

Post-Santa Fe Group deposits in this area chiefly consist of unconsolidated fluvial, alluvial, colluvial, and eolian sediments. They were deposited widely in the basin in various geomorphic settings related to incision of the Rio Grande, continued rift faulting, and development of the modern landscape. The younger basalt flows and pyroclastic deposits at Los Lunas (1.14 Ma) were erupted over the youngest Santa Fe Group deposits in that location. The Cat Hills basalt (98-110 ka) flows were 
erupted over inset terrace deposits of the Los Duranes formation of Lambert (1968).

\section{Cenozoic Structural Geology}

Dominantly north-trending faults have been active during Neogene time and are prominent in the landscape. They crosscut older northwest-trending faults that segmented the Rio Grande rift into multiple sub-basins. The western basin margin is characterized by numerous normal faults that generally show down-to-theeast displacement, but several minor down-to-the west faults form the boundaries of local horsts and grabens. The eastern basin margin is defined by numerous down-to-the-west normal faults such as the Manzanita, Manzano Mountains, and Hubbell Spring fault zones. The Hubbell Spring fault zone is a major intrabasinal structure that bounds a shallow bench of Permian and Triassic rocks against Neogene Santa Fe Group sediments of the easternmargin and central-basin facies.

Map relationships and aeromagnetic, gravity, and drillhole data all suggest that the Tijeras fault zone is either cut by, or merges with, the western Hubbell Spring fault and the southern Sandia fault, and is not expressed southwestward across the basin. Our studies do not support the presence of the inferred northtrending Rio Grande fault of Russell and Snelson (1994) in this area. We interpret an older (late Oligocene(?) to Miocene) fault (called the Mountainview fault zone by Maldonado and others, 1999) to have formed the margin of a northwest-trending depositional basin (Isleta Pueblo graben), was subsequently cut by north-trending faults.

\section{References}

Bachman, G.0., and Mehnert, H.H., 1978, New K-Ar dates and the late Pliocene to Holocene geomorphic history of the central Rio Grande region, New Mexico: Geological Society of America Bulletin, v. 89, p. 283-292.

Baldridge, W.S., Perry, F.K., and Shafiqullah, M., 1987, Late Cenozoic volcanism of the southeastern Colorado Plateau: I. Volcanic geology of the Lucero area, New Mexico: Geological Society of America Bulletin, v. 99, p. 463-470

Lambert, P.W., 1968, Quaternary stratigraphy of the Albuquerque area, New Mexico: Ph.D. thesis, University of New Mexico, Albuquerque, $329 \mathrm{p}$.

Lozinsky, R.P. 1994, Cenozoic stratigraphy, sandstone petrology, and depositional history of the Albuquerque Basin, New Mexico: Geological Society of America, Special Paper 291, p. 73-81.

Lozinsky, R.P., and Tedford, R.H., 1991, Geology and paleontology of the Santa Fe Group, southwestern Albuquerque Basin, Valencia County, New Mexico: New Mexico Bureau of Mines and Mineral Resources, Bulletin 132, $35 \mathrm{p}$.

Maldonado, F., Connell, S.D., Love, D.W., Grauch, V.J.S., Slate, J.L., Mclntosh, W.C., Jackson, P.B., and Byers, F.M. Jr., 1999, Neogene geology of the Isleta Reservation and vicinity, Albuquerque Basin, central New Mexico: New Mexico Geological Society Guidebook, Albuquerque Geology 1999, p.175-188.

Russell, L.R., and Snelson, S., 1994, Structure and tectonics of the Albuquerque Basin segment of the Rio Grande rift: Insights from reflection seismic data, in Keller, G.R., and Cather, S.M., eds., Basins of the Rio Grande rift: Structure, stratigraphy, and tectonic setting: Geological Society of America, Special Paper 291, p. 83-112. 


\title{
REGIONAL GEOLOGIC AND HYDROLOGIC MODELING
}

\section{3-D Geologic Modeling of Regional Hydrostratigraphic Units in the Albuquerque Segment of the Rio Grande Rift}

\author{
James C. Cole \\ U.S. Geological Survey, MS 913, Box 25046, Denver C0 80225-0046
}

\section{Introduction}

One of the principal products of this five-year collaborative investigation is a revised ground-water flow model for the Middle Rio Grande basin, as described in Chapter J (following; McAda and others, 2000). The framework for that flow model is an improved regional-scale model of the distribution and continuity of major hydrostratigraphic units in the aquifer system. The revised geologic model is based on the results of the detailed geologic mapping that has been conducted by the U.S. Geological Survey, the New Mexico Bureau of Mines and Mineral Resources, and the University of New Mexico. In addition, considerable insight to the 3-D distribution of geologic units has been borne out by new geophysical investigations (Chapter A; Grauch and others, 2000; Chapter G, Rodriguez and others, 2000) and re-interpretations of existing data.

The revised geologic model was also based on stratigraphic and lithologic interpretations of the sediments penetrated by numerous wells in the basin. In particular, careful consideration was given to the stratigraphic interpretations of Lozinsky (1988, 1994) for 12 deep oil-exploration wells from the central and southern parts of the system, to interpretations from dozens of water wells in the central part of the system around Albuquerque and Rio Rancho (Hawley and Haase, 1992; Hawley and others, 1995; Connell and others, 1998; and Connell, written commun.). Data became available from measured sections (Connell and others, 1999; USGS unpublished data), additional oil-exploration test wells, and several private water exploration wells during the course of this synthesis that were incorporated in the model framework. The stratigraphic framework that emerged from our regional analysis is described in Chapter D (Stone and others,

2000). We performed an independent interpretation of drill hole geophysical logs for many of the wells, using an empirical semiquantitative method to identify dominant grain-size characteristics of rift-fill sediments.

The goal of this synthesis and analysis was to define regional-scale hydrostratigraphic units that could be defined and delimited in the subsurface of this complex of interconnected rift basins. These units were extended within and across the structural sub-basins of the overall rift environment by relying on the scant drill hole data and some geophysical constraints, where available. In general, however, such data and constraints were lacking for major parts of the geologic model, and so the delimitation of hydrostratigraphic units was based on a conceptual understanding of overall rift history and the expected relationships between tectonic deformation and sedimentation (see Chapters D and E; Stone and others, 2000; Stone, 2000).

\section{Approach}

We define the extent of the aquifer system as coincident with the rift-fill sediments of the Santa Fe Group, chiefly Miocene and younger in age. Oligocene units identified in outcrop are more lithified and are distinguishable in well logs by higher typical density values (Lozinsky, 1988, 1994). The increase in density of prerift sediments allowed us to use the regional gravity data (Grauch and others, 2000) to calculate the bottom of the aquifer system. A gridded array of thickness values for the low-density rift-fill sediments could then be subtracted from the land-surface elevation data to define the 3-D location of the base of the aquifer. This procedure dramatically reveals the important substructure of the "Middle Rio Grande basin", which consists of discrete deep subbasins in the northern and central areas and a highly irregular basin complex in the south (fig. I-1).

Faults are important structural and hydrologic elements in the aquifer framework, and several sources of data were used to identify the principal fault zones in the basins. Sharp gradient zones in the gravity data indicate boundaries of major blocks of basement-density material, and these zones largely coincide with north- and northwest-trending margins of the deeper (older) parts of the structural sub-basins. Younger faults that are manifest in the near-surface geology chiefly trend north-south and reflect the dominant extension direction during the last 5 million years (Minor and Hudson, 2000). We compared independent compilations of fault trends based on aeromagnetic lineament data (Grauch and others, 2000), topographic scarps defined by digital elevation data, mapped fault zones, and fault scarps known or inferred to reflect Quaternary offset (Machette and others, 1998). This comparison indicated a few more than 20 major fault structures within the Middle Rio Grande basin complex have sufficient length, continuity and throw that warrant inclusion in the framework model (see fig. I-1).

The hydrostratigraphic units distributed through the 3-D geologic model are necessarily simple and coarsely defined, as required for the regional scale of the model. Nonetheless, they are 
consistently defined on the basis of overall grainsize and bedding characteristics that reflect the conceptual sedimentological controls on deposition during rift-basin subsidence (Stone, 2000; Stone and others, 2000). The lowest units in the northern and southern sub-basins are dominantly volcaniclastic sand and gravel reflecting erosion of volcanic source terranes outside the rift basin; the oldest unit in the central sub-basin is chiefly eolian sand and playa silt and clay. The thick and variable middle section of all three sub-basins is composed of fluvial sand and silt derived from various external sources and accumulated in depo-centers through much of Miocene time while faulting was quite active and climate was temperate. The uppermost blanketing unit in all three subbasins consists of coarse gravel and sand that reflect a regional change to wetter climate at about $5 \mathrm{Ma}$ (Raymo and Ruddiman, 1992). Sometime after 2.7 Ma (Kelley and Kudo, 1978), ancestral Rio Grande drainage was integrated through and below this region and the river system began to incise the existing basin fill. This inset post-Santa Fe fluvial unit is the uppermost hydrogeologic zone in the regional 3-D model.

\section{Result}

The 3-D model of the regional hydrogeology of the Rio Grande rift in the Middle Rio Grande basin was constructed from the data listed above using Earth Vision geologic modeling software by Dynamic Graphics, Inc. Serial slices through the model volume are depicted on the front cover illustration of this report. The modeling system allowed us to explicitly honor all points of known data (outcrop locations, drill hole intercepts), to tentatively honor inferred data points (for example, interpretations from geophysical data, projections from cross-sections, etc.), and to adjust limiting (control) data points in defining the surfaces that bound hydrostratigraphic units. We were also able to define offset relationships across faults, to varying degrees. The release version of Earth Vision we used for model construction was optimized to maintain stratigraphic unit thickness across faults, and that optimization presented some challenges in depicting the growth-fault relationships that are typical within the Rio Grande rift. Overall, the software performed admirably and allowed us to construct a complete and quite realistic basin model.

Gridded data points were exported directly from the Earth Vision model listing the elevation of the top of each hydrostratigraphic unit at the UTM grid locations of cell boundaries in the MODFLOW ground-water flow model (McAda and others, 2000). Similarly, gridded data were exported directly from the geology model that defined the location and extent of each of the major faults in the model. In this fashion, we were able to convert the Earth Vision geology model directly into input for the MODFLOW model in less than one week, with no distortion or loss of detail. Simpler geologic environments, characterized by hydrostratigraphic units that were more tabular and by post-depositional fault offsets, could be modeled even more expediently.

\section{References}

Connell, S.D., Allen, B.D., and Hawley, J.W, 1998, Subsurface stratigraphy of the Santa Fe Group from borehole geophysical logs, Albuquerque area, New Mexico: New Mexico Geology, vol. 20, no. 1, p. 2-7.

Connell, S.D., Koning, D.J., and Cather, S.M., 1999, Revisions to the stratigraphic nomenclature of the Santa Fe Group, northwestern Albuquerque basin, New Mexico: New Mexico Geological Society Guidebook, 50 ${ }^{\text {th }}$ Field Conference, Albuquerque Geology, p. 337-353.

Grauch, V.J.S., Sawyer, D.A., Keller, G. R., and Gillespie, C.L., 2000, Contributions of gravity and aeromagnetic studies to improving the understanding of subsurface hydrogeology, Middle Rio Grande basin, New Mexico. This volume.

Hawley, J.W, and Haase, C.S., 1992, Hydrogeologic frameowrk of the northern Albuquerque basin: New Mexico Bureau of Mines and Mineral Resources Open-File Report 387, 73 p.

Hawley, J.W, Haase, C.S., and Lozinsky, R.P., 1995, An underground view of the Albuquerque basin, in Ortega-Klett, C.T. (ed.), The water future of Albuquerque and the Middle Rio Grande basin: New Mexico Water Resources Research Institute, Technical Report 290, p. 37-55.

Kelley, V.C., and Kudo, A.M., 1978, Volcanoes and related basalts of Albuquerque basin, New Mexico: New Mexico Bureau of Mines and Mineral Resources Circular 156, $30 \mathrm{p}$.

Lozinsky, R.P., 1988, Stratigraphy, sedimentology, and sand petrology of the Santa Fe Group and pre-Santa Fe Tertiary deposits in the Albuquerque basin, central New Mexico: Socorro, New Mexico, New Mexico Tech, Ph.D. disseratation, 298 p.

Lozinsky, R.P., 1994, Cenozoic stratigraphy, sandstone petrology, and depositional history of the Albuquerque basin, central New Mexico, in Keller, G.R., and Cather, S.M. (eds.), Basins of the Rio Grande rift: Geological Society of America, Special Paper 291, p. 73-82.

Machette, M.N., Personius, S.F., Kelson, K.I., Haller, K.M., and Dart, R.L., 1998, Map and data for Quaternary faults in New Mexico: U.S. Geological Survey Open-File Report 98-521, 443 p.

McAda, D.P., Barroll, Peggy, and Sanford, W.E., 2000, Revision of the ground-water-flow model of the Middle Rio Grande basin, New Mexico. This volume.

Minor, S.A., and Hudson, M.R., 2000, Structural and physical properties and cementation patterns of fault zones in the northern Albuquerque basin, New Mexico: implications for ground-water flow: U.S. Geological Survey Bulletin [in press, 2000], $43 \mathrm{~ms}$ p.

Stone, B.D., 2000, Sedimentary, stratigraphic, and hydrologic consequences of syn-depositional faulting in the Rio Grande rift. This volume.

Stone, B.D., Cole, J.C., and Sawyer, D.A., 2000,Regional stratigraphic framework of the three-dimensional geologic model of the Rio Grande rift. This volume. 


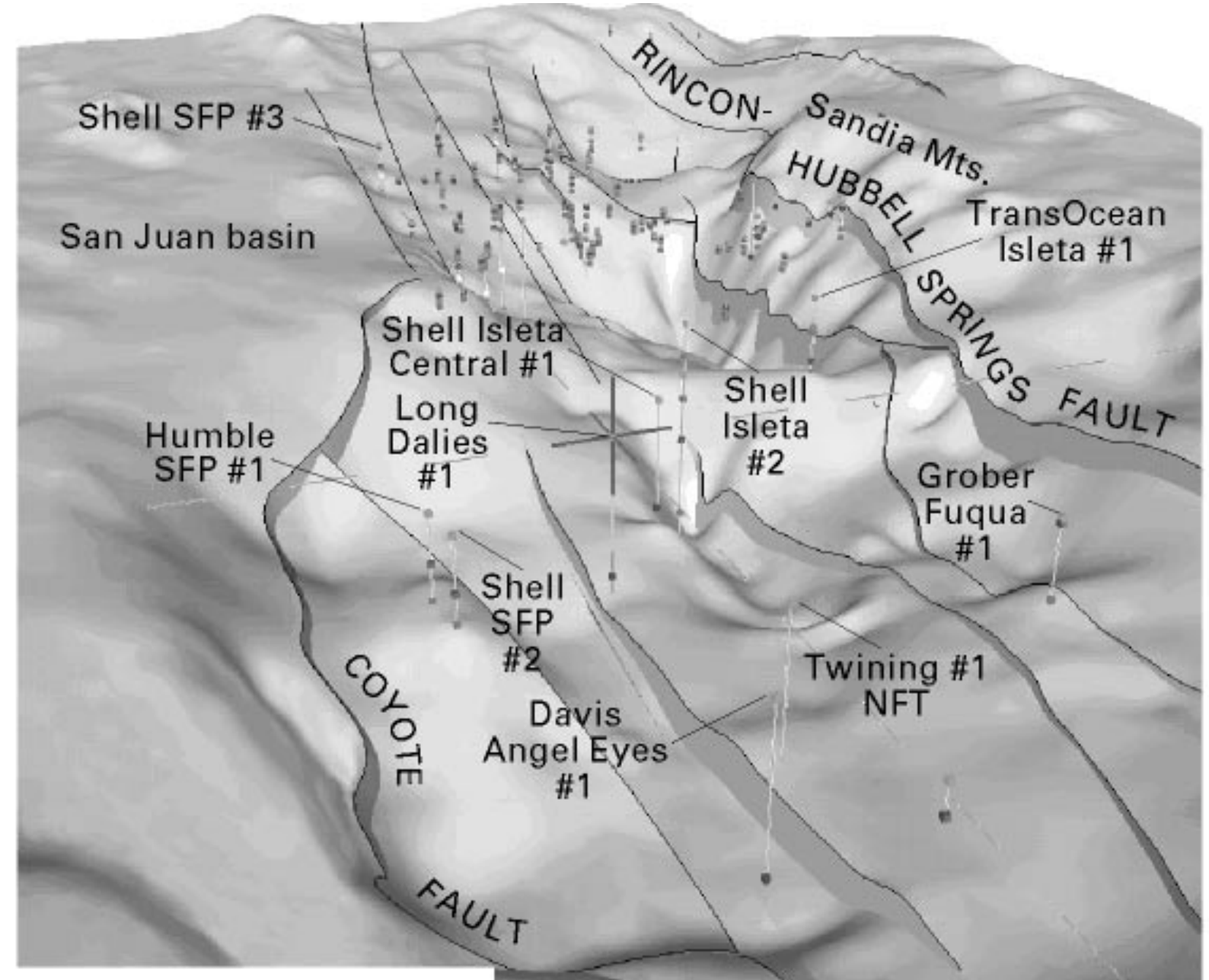

\section{COLOR KEY}

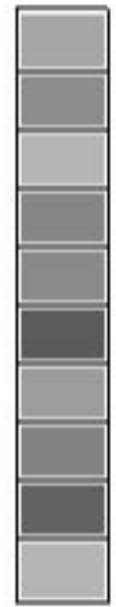

Axial gravel

Gravel

Medium/coarse sand

Silt, sand

Medium sand

Fine/medium sand

Eolian sand, silt

Volcaniclastic sand

Piedmont deposits

Pre-Santa Fe Group

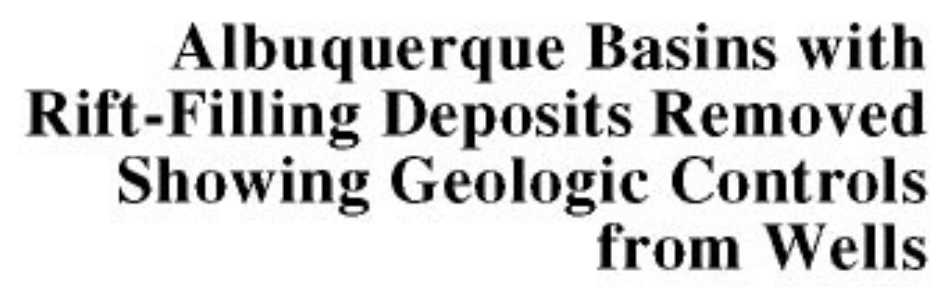

Figure I-1. Perspective view of the faulted pre-Santa Fe Group surface beneath the Albuquerque basin 


\title{
J. Revision of the Ground-water-flow Model of the Middle Rio Grande Basin, New Mexico
}

\author{
Douglas P. McAda ${ }^{1}$, Peggy Barroll ${ }^{2}$, and Ward E. Sanford ${ }^{3}$ \\ ${ }^{1}$ U. S. Geological Survey, 5338 Montgomery NE, Suite 400, Albuquerque NM 87109-1311 \\ ${ }^{2}$ New Mexico Office of the State Engineer, P.O. Box 25102, Santa Fe NM 87504 \\ ${ }^{3}$ U. S. Geological Survey, MS 431, National Center, Reston VA 20192
}

\section{Introduction}

The U.S. Geological Survey (USGS) Middle Rio Grande Basin (MRGB) study was initiated in 1995 to "improve the understanding of hydrology, geology, and land-surface characteristics of the Middle Rio Grande Basin" (Bartolino, 1997). The information gained from this study and related activities are being used to develop an updated three-dimensional finite-difference ground-water-flow model of the basin. Previous ground-waterflow models of the basin were developed by Kernodle and others (1995), Kernodle (1998), Tiedeman and others (1998), and Barroll (1999). The objectives for this model are to integrate the understanding of the geologic, hydrologic, and aquifer-stress components of the surface-water/ground-water system to provide a quantitative picture of the basin-wide aquifer system and to provide an administrative tool for water-resource management in the basin. Administration of ground water and surface water in the basin are closely related. Therefore, a principal objective of the model is to simulate the interaction between the aquifer and surface water in the perennial rivers located near major pumping centers-the Rio Grande and Jemez River.

Model development is being done in cooperation among the USGS, the New Mexico Office of the State Engineer, and the City of Albuquerque.

\section{Ground-water Model Parameters}

The numerical ground-water-flow model incorporates the Santa Fe Group aquifer system from the vicinity of Cochiti Lake on the north to San Acacia on the south. The model area is divided into a rectilinear grid of equally spaced 1-square-kilometer size cells. Model simulations are being made using nine model layers. The uppermost model layer varies in thickness depending on the water-table altitude; the layer is about 6 meters thick directly below the Rio Grande and is greater than 100 meters thick along parts of the basin margin. Each of the next six layers is constant thickness throughout the model, but each deeper layer is progressively thicker (about 18 to 300 meters thick, extending to about 730 meters below the Rio Grande riverbed). Layers eight and nine are variable in thickness and represent the aquifer system from the bottom of layer seven to the base of the Santa Fe Group. Layer eight ranges in thickness from about 120 to 900 meters, and layer nine ranges in thickness from about 240 to 1,800 meters. The saturated thickness of the aquifer diminishes near the margins of the basin; therefore, the number of active cells in each model layer is smaller for successively deeper layers. Layer one contains about 6,200 active cells, and layer nine contains about 4,500 active cells. The model contains about 51,000 active cells in total.

\section{Geologic Input to the Model}

The geologic framework for the ground-water-flow model was derived from the geologic model of the basin described by Cole and others (1999; Cole, 2000). This geologic model describes the base of the Santa Fe Group, locations of major faults, and the distribution of nine lithostratigraphic units throughout the basin (Cole and others, 1999; Grauch and others, 1999; Hudson and others, 1999). Buried volcanic and intrusive rocks (Grauch and others, 1999) and alluvium of the inner Rio Grande valley (Hawley and Haase, 1992) also were included in the geologic framework for the ground-water model.

\section{Hydrologic Fluxes in the Model}

Aquifer recharge at the basin margins in the model simulations includes recharge along mountain fronts and lateral inflow from adjacent ground-water flow systems. For simulation purposes, mountain-front recharge is defined as recharge from water originating as precipitation in the adjacent watersheds draining to the basin and entering the basin as shallow ground-water inflow or as infiltration of surface water in the immediate vicinity of the mountain front. Mountain-front recharge is simulated for the Jemez Mountains in the north of the basin, the Sandia, Manzanita, Manzano, and Los Pinos Mountains along the east, and Ladron Peak in the southwest. Mountain-front recharge is input to cells in the uppermost active layer of the model as specified fluxes of water. Lateral inflow from adjacent ground-water systems enters the basin at depth in the aquifer system. Most of the simulated lateral ground-water inflow from adjacent basins is from the Española Basin, including underflow from beneath the Jemez Mountains (Grant, 1999). Smaller volumes of water are simulated as inflow from the San Juan Basin and south along the western margin of the Middle Rio Grande Basin. Inflow from adjacent ground-water flow systems is input to cells below the top model layer as specified fluxes of water.

Recharge from or discharge to streams in the interior of the basin is simulated as either specified or head-dependent fluxes of water. Recharge from the Santa Fe River, Galisteo Creek, Tijeras 
Arroyo, Abo Arroyo, Rio Salado (in the southern part of the basin), Rio Puerco, and the portion of the Jemez River adjacent to the model boundary are input to cells in the uppermost active layer of the model as specified fluxes of water. Recharge from or discharge to the Rio Grande and the reach of the Jemez River extending into the basin are simulated in the model as head-dependent fluxes of water. If the river stage is greater than the head in the underlying cell, recharge to the aquifer occurs; if head in the cell is greater than river stage, discharge from the aquifer to the river occurs.

Evapotranspiration from natural vegetation and wetlands in the inner Rio Grande valley is simulated in the model as headdependent fluxes of water discharging from the aquifer. The model does not simulate evapotranspiration from irrigated areas such as yards, parks, and agricultural fields separately because it comes from the applied irrigation water.

The irrigation system along the Rio Grande inner valley consists of canals and drains. Canal and drain features are being updated for the model on the basis of information provided by the Middle Rio Grande Conservancy District. The canals convey water from the Rio Grande to irrigated fields. Leakage from canals and the irrigated fields is input to cells in the uppermost active model layer as specified fluxes of water. The drains intercept seepage from the Rio Grande and from applied irrigation water that contributed to waterlogging of land in the inner valley prior to their installation. Collectively, the drains discharge water from the aquifer; however, some drain reaches can recharge water to the aquifer depending on the water stage in the drain relative to the head in the aquifer. Therefore, discharge to or recharge from the drains is simulated as head-dependant fluxes of water.

Withdrawals of water by wells in the aquifer system are input to the model as specified fluxes of water discharged from the aquifer at model cells that best represent the locations of the well screens. Ground-water withdrawal for 1901-98 is included in the historical model simulations. Some water withdrawn by wells is returned to the aquifer as leakage from septic leach fields, which is input to the model as specified fluxes of water to the uppermost active model layer.

\section{References}

Barroll, Peggy, 1999, Draft documentation of the administrative groundwater model for the Middle Rio Grande Basin: New Mexico Office of the State Engineer Hydrology Bureau Report 99-3,
Bartolino, J.R., (ed.), 1997, U.S. Geological Survey Middle Rio Grande Basin Study-Proceedings of the first annual workshop, Denver, Colorado, November 12-14, 1996: U.S. Geological Survey Open-File Report 97-116, $91 \mathrm{p}$.

Cole, J.C., Grauch, V.J.S., Hudson, M.R., Maldonado, Florian, Minor, S.A., Sawyer, D.A., Stone, B.D., 1999, Three-dimensional geologic modeling of the Middle Rio Grande Basin, in Bartolino, J.R., (ed.), U.S. Geological Survey Middle Rio Grande Basin Study-Proceedings of the third annual workshop, Albuquerque, New Mexico, February 24-25, 1999: U.S. Geological Survey Open-File Report 99-203, p. 25-27.

Cole, J.C., 2000, 3-D geologic modeling of regional hydrostratigraphic units in the Albuquerque segment of the Rio Grande rift. This volume.

Grant, P.R., 1999, Subsurface geology and related hydrologic conditions, Santa Fe Embayment and contiguous areas, New Mexico, in Pazzaglia, F.J., Lucas, S.G., and Austin, G.S., (eds.), Albuquerque Geology, New Mexico Geological Society Fiftieth Annual Field Conference, September 22-25, 1999, p. 425-435.

Grauch, V.J.S., Gillespie, C.L., Sawyer, D.A., and Keller, G.R., 1999, Subsurface constraints on the geologic model of the Middle Rio Grande Basin, including new high-resolution aeromagnetic data and gravity modeling, in Bartolino, J.R., (ed.), U.S. Geological Survey Middle Rio Grande Basin Study-Proceedings of the third annual workshop, Albuquerque, New Mexico, February 24-25, 1999: U.S. Geological Survey Open-File Report 99-203, p. 37-39.

Hawley, J.W., and Haase, C.S., 1992, Hydrogeologic framework of the northern Albuquerque Basin: New Mexico Bureau of Mines and Mineral Resources Open-File Report 387, variously paged.

Hudson, M.R., Minor, S.A., Grauch, V.J.S., and Personius, S.F., 1999, Preliminary characterization of faults in the Middle Rio Grande Basin, in Bartolino, J.R., (ed.), U.S. Geological Survey Middle Rio Grande Basin Study-Proceedings of the third annual workshop, Albuquerque, New Mexico, February 24-25, 1999: U.S. Geological Survey Open-File Report 99-203, p. 40-41.

Kernodle, J.M., 1998, Simulation of ground-water flow in the Albuquerque Basin, Central New Mexico, 1901-95, with projections to 2020 (Supplement two to U.S. Geological Survey Water-Resources Investigations Report 94-4251): U.S. Geological Survey Open-File Report 96-209, $54 \mathrm{p}$.

Kernodle, J.M., McAda, D.P., and Thorn, C.R., 1995, Simulation of groundwater flow in the Albuquerque Basin, Central New Mexico, 19011994, with projections to 2020: U.S. Geological Survey WaterResources Investigations Report 94-4251, 114 p.

Tiedeman, C.R., Kernodle, J.M., and McAda, D.P., 1998, Application of nonlinear-regression methods to a ground-water flow model of the Albuquerque Basin, New Mexico: U.S. Geological Survey WaterResources Investigations Report 98-4172, 90 p. 


\title{
INTERACTIONS BETWEEN THE RIO GRANDE AND AOUIFER SYSTEM
}

\section{K. Temperature Profiles of the Aquifer System Underlying the Rio Grande, Middle Rio Grande Basin, New Mexico — fourth-year Status}

\author{
James R. Bartolino ${ }^{1}$ and Richard G. Niswonger ${ }^{2}$ \\ ${ }^{1}$ U.S. Geological Survey, 5338 Montgomery NE, Suite 400, Albuquerque NM 87109-1311 \\ ${ }^{2}$ U.S. Geological Survey, Carson City NV 89706
}

\section{Introduction}

An important gap in the understanding of the hydrology of the Middle Rio Grande Basin, central New Mexico, is the rate at which water from the Rio Grande recharges the Santa Fe Group aquifer system. Several methodologies-including use of the Glover-Balmer equation, flood pulses, and channel permeameters-have been applied to this problem. Ground-water temperature profiles and ground-water levels beneath the Rio Grande were measured and numerically simulated at four sites. The direction and rate of vertical ground-water flux between the river and underlying aquifer were simulated, and the effective vertical hydraulic conductivity of the sediments underlying the river was estimated through model calibration.

\section{Methods}

Seven sets of nested piezometers were installed during July and August 1996 at four sites along the Rio Grande in the Albuquerque area. However, simulation conditions are reported here for only four of the piezometer nests. In downstream order, these four sites are (1) the Bernalillo site, upstream from the New Mexico State Highway 44 bridge in Bernalillo (piezometer nest BRN02); (2) the Corrales site, upstream from the Rio Rancho sewage treatment plant in Rio Rancho (COR01); (3) the Paseo del Norte site, upstream from the Paseo del Norte bridge in Albuquerque (PDN01); and (4) the Rio Bravo site, upstream from the Rio Bravo bridge in Albuquerque (RBR01). All piezometers were completed in the inner-valley alluvium of the
Santa Fe Group aquifer system. Ground-water levels and temperatures were measured in the four piezometer nests a total of seven times in the 24-month period from September 1996 through August 1998.

The flux between the surface- and ground-water systems at each of the sites was quantified by one-dimensional numerical simulation of the water and heat exchange in the subsurface using the heat and water transport model VS2DH. Model calibration was aided by the use of PEST, a model-independent computer program that uses nonlinear parameter estimation.

\section{Results}

Mean simulated vertical ground-water flux is $3.30 \times 10^{-7}$ meters per second $(\mathrm{m} / \mathrm{s})$ for the BRN02 piezometer nest; $3.58 \times 10^{-7} \mathrm{~m} / \mathrm{s}$ for the COR01 piezometer nest $4.22 \times 10^{-7} \mathrm{~m} / \mathrm{s}$ for the PDN01 piezometer nest; and $2.05 \times 10^{-7} \mathrm{~m} / \mathrm{s}$ for the RBR01 piezometer nest. Mean vertical hydraulic conductivities estimated by model calibration range from $1.5 \times 10^{-5}$ to $5.8 \times 10^{-6} \mathrm{~m} /$ s. Comparison of the simulated vertical fluxes and vertical hydraulic conductivities derived from this study with values from other studies in the Middle Rio Grande Basin indicate agreement within 1 order of magnitude for vertical flux and between 1 and 3.5 orders of magnitude for hydraulic conductivity. The final report "Numerical simulation of vertical groundwater flux of the Rio Grande from ground-water temperature profiles, central New Mexico" by J.R. Bartolino and R.G. Niswonger, was published as Water-Resources Investigations Report 99-4212. 


\title{
L. Use of Temperature to Delineate Water Movement Between the Rio Grande, Riverside Drains, and Santa Fe Group Aquifer System at the Paseo Del Norte Bridge, Albuquerque, New Mexico
}

\author{
James R. Bartolino ${ }^{1}$ and Amy E. Stewart ${ }^{2}$ \\ 1U. S. Geological Survey, 5338 Montgomery NE, Suite 400, Albuquerque NM 87109-1311 \\ ${ }^{2}$ U. S. Geological Survey, MS 496, Menlo Park CA 94025
}

\section{Introduction}

An important gap in the understanding of the hydrology of the Middle Rio Grande Basin, central New Mexico, is the rate at which water from the Rio Grande recharges the Santa Fe Group aquifer system. (The Santa Fe Group aquifer system, as defined by Thorn, McAda, and Kernodle (1993), is composed of Santa Fe Group sediments as well as hydraulically connected post-Santa Fe Group valley and basin-fill deposits). Several methodologies, including the Glover-Balmer equation (Glover and Balmer, 1954), flood pulses (Pruitt and Bowser, 1994; Roark, 1998), channel permeameters (Gould, 1994), ground-water temperature profiles (Bartolino and Niswonger, 1999), and numerical simulation (Kernodle, McAda, and Thorn, 1995) have been used to estimate the rate of recharge from the Rio Grande. One of the limitations of Bartolino and Niswonger's (1999) study using ground-water temperature profiles is that only the vertical components of ground-water flux and hydraulic conductivity were quantified. Although the vertical component of these two properties probably accounts for the major portion of streambed infiltration, it does not address what percentage of Rio Grande infiltration discharges to the riverside drains and returns to the river.

\section{Methods}

Eight piezometer nests were installed by the U.S. Geological Survey (USGS) in an east-trending line across the Rio Grande, north of the Paseo del Norte bridge in Albuquerque (fig. L-1). The piezometer nests are located on the east bank of the Corrales Riverside drain (P01), midway between the Corrales Riverside drain and river (P02), on the west bank of the river (P03), on a sandbar in the active river channel (P04 and P05), on the east bank of the river (P06), midway between the river and Albuquerque Riverside drain (P07), and on the west bank of the Albuquerque Riverside drain (P08). Each piezometer nest consists of three piezometers installed approximately 3, 7, and 13 meters below land surface. Automated data loggers collect ground-water temperatures at five depths (approximately 2, 4, 6, 8, and 11 meters) in each piezometer nest at 1-hour intervals; ground-water levels are measured every 2 weeks. In addition, data loggers are collecting surfacewater temperatures at two locations in each drain and in the Rio Grande at 1-hour intervals. Finally, stage measurements of the Rio Grande were collected every 15 minutes at the USGS streamflow gaging station (Rio Grande near Alameda-08329928), located immediately south of the Paseo del Norte bridge.

Data collection began in March 1999 and has continued through June 2000. Data collected for this study are to be analyzed using the two-dimensional heat and water transport model VS2DH (Healy and Ronan, 1996). The goal is to quantify horizontal and vertical ground-water fluxes from the Rio Grande, horizontal and vertical hydraulic conductivities of the post-Santa Fe Group valley and basin-fill deposits, and ground-water fluxes into the riverside drains.

\section{References}

Bartolino, J.R., and Niswonger, R.G., 1999, Numerical simulation of vertical ground-water flux of the Rio Grande from ground-water temperature profiles, central New Mexico: U.S. Geological Survey WaterResources Investigations Report 99-4212, 34 p.

Glover, R.E., and Balmer, C.G., 1954, River depletion resulting from pumping a well near a river: American Geophysical Union Transactions, v. 35, no. 3, p. 468-470.

Gould, Jaci, 1994, Middle Rio Grande permeameter investigations: Albuquerque, U.S. Bureau of Reclamation Technical Memorandum, December 1994, 13 p., attachments.

Healy, R.W., and Ronan, A.D., 1996, Documentation of computer program VS2DH for simulation of energy transport in variably saturated porous media-Modification of the U.S. Geological Survey's computer program VS2DT: U.S. Geological Survey Water-Resources Investigations Report 96-4230, $36 \mathrm{p}$.

Kernodle, J.M., McAda, D.P., and Thorn, C.R., 1995, Simulation of groundwater flow in the Albuquerque Basin, central New Mexico, 19011994, with projections to 2020: U.S. Geological Survey WaterResources Investigations Report 94-4251, 114 p., 1 pl.

Pruitt, Tom, and Bowser, Steve, 1994, Flood wave test and transient groundwater analysis: Albuquerque, U.S. Bureau of Reclamation Technical Memorandum, May 1994, 24 p., appendixes, 1 diskette in pocket.

Roark, D.M., 1998, Use of surface-water pulses to estimate hydraulic characteristics of the Rio Grande alluvium, Albuquerque area, New Mexico, in Slate, J.L., ed., 1998, U.S. Geological Survey Middle Rio Grande Basin Study-Proceedings of the Second Annual Workshop, Albuquerque, New Mexico, February 10-11, 1998: U.S. Geological Survey Open-File Report 98-337, p. 53-54.

Thorn, C.R., McAda, D.P., and Kernodle, J.M., 1993, Geohydrologic framework and hydrologic conditions in the Albuquerque Basin, central New Mexico: U.S. Geological Survey Water-Resources Investigations Report 93-4149, 106 p., 1 pl. 


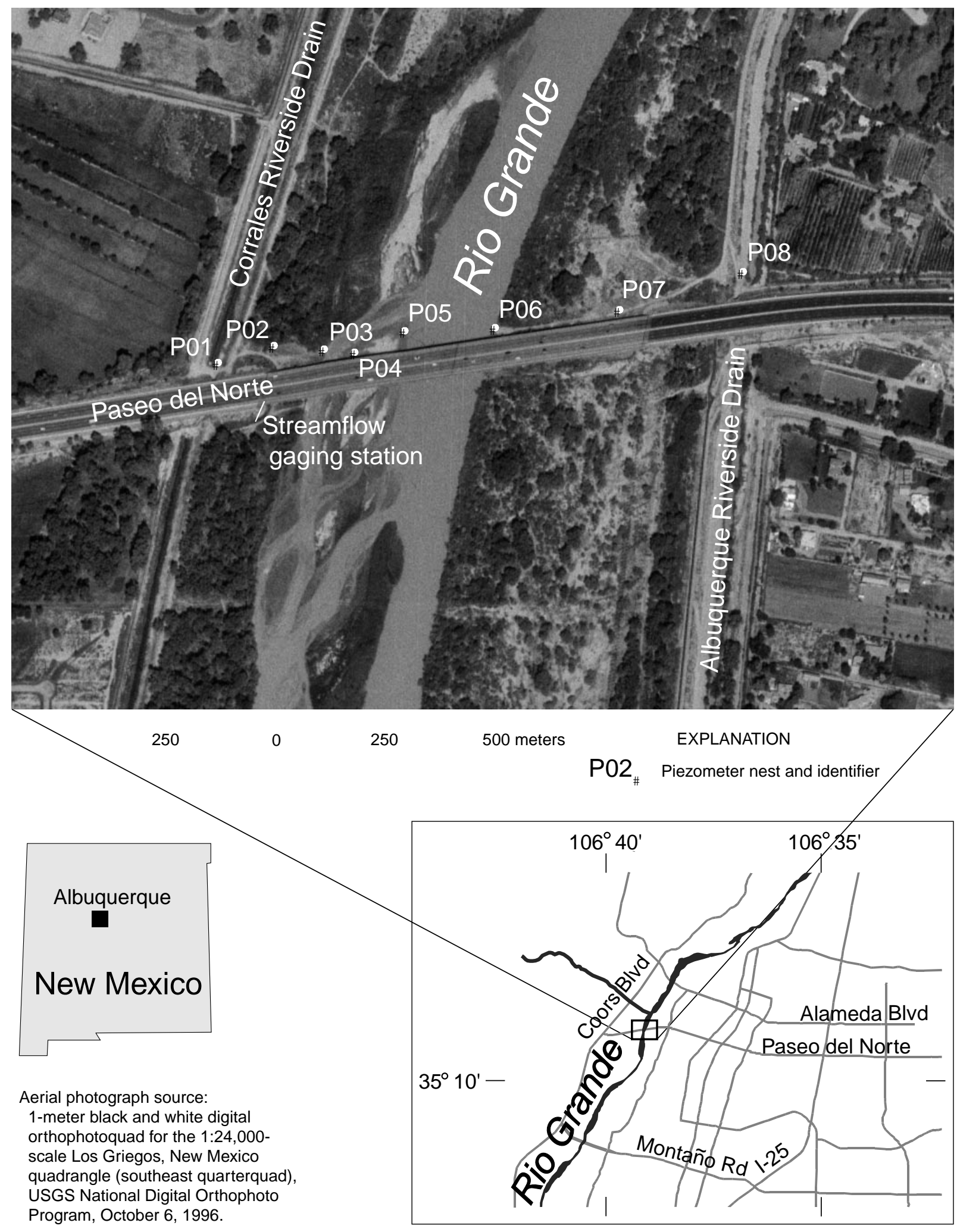

Figure L-1. Location of the study area and annotated aerial photography of the study site. 


\title{
M. Electromagnetic Surveys in the Rio Grande Flood Plain, Middle Rio Grande Basin, New Mexico-Fourth-year Status
}

\author{
James R. Bartolino ${ }^{1}$ and Joseph M. Sterling ${ }^{2}$ \\ ${ }^{1}$ U. S. Geological Survey, 5338 Montgomery NE, Suite 400, Albuquerque NM 87109-1311 \\ ${ }^{2}$ New Mexico Institute of Mining and Technology, Socorro NM 87801
}

\section{Introduction and Methods}

Information on the distribution and geometry of clay-rich layers in the inner-valley alluvium is essential for quantifying the amount of water transmitted between the Rio Grande and the Santa Fe Group aquifer system. A study conducted by the U.S. Geological Survey used electromagnetic surveys to provide this information.

In the first phase of the study (1996), electromagnetic soundings were made using time-domain and frequency-domain electromagnetic methods. Based on initial results, the time-domain method was judged ineffective because of anomalies caused by man-made conductors in the study area. As a result, subsequent surveys were made using the frequency-domain method. In the second phase of the study completed in the spring and summer of 1997, 31 frequency-domain electromagnetic surveys were obtained. These surveys covered traverses along the inner valley and parallel to the Rio Grande in the Albuquerque area to determine the distribution and geometry of hydrologically significant clay-rich layers buried in the inner-valley alluvium. The 31 survey sections were combined into 10 composite sections to assist interpretation.

\section{Results}

Terrain-conductivity data from the surveys were modeled to produce geoelectric cross sections along the survey lines.
This modeling used lithologic logs from two wells installed near the survey lines: the Bosque South and Rio Bravo 5 wells. Our interpretation of the model was inconclusive because we encountered considerable electrical interference from manmade objects, and because of complex stratigraphy and difficulty in relating drillhole lithology to the soundings. Instead, we developed a decision process based on modeling results, in which stations with both vertical and horizontal dipole 40-m intercoil spacing terrain-conductivity values larger than 20 millisiemens per meter were interpreted to contain a hydrologically significant thickness of clay-rich sediment (with some qualifiers).

By this alternate process, we interpret a hydrologically significant thickness of clay-rich sediment to underlie seven segments of the 10 composited survey lines, totaling at least 2,660 meters of Rio Grande inner valley. The longest of these segments is a 940-meter reach between Rio Bravo Boulevard and Bridge Boulevard.

The final report "Electromagnetic surveys to detect clayrich sediment in the Rio Grande inner valley, Albuquerque Area, New Mexico" by J.R. Bartolino and J.M. Sterling was published in 2000 as Water-Resources Investigations Report 00-4003. 


\title{
N. Determination of Streamflow Patterns to Estimate Stream Loss Along Abo Arroyo, New Mexico
}

\author{
Amy E. Stewart ${ }^{1,2}$ and Jim Constantz ${ }^{1}$ \\ ${ }^{1}$ U.S. Geological Survey, MS 496, Menlo Park CA 94025 \\ ${ }^{2}$ Dept. of Civil \& Environmental Engineering, Stanford University, Stanford CA 94305
}

\section{Introduction}

Abo Arroyo is the largest stream within the southeastern portion of the Middle Rio Grande Basin. Although Abo Arroyo is ephemeral, it may be the largest source of groundwater recharge in this portion of the basin. The losing reach of Abo Arroyo enters the Middle Rio Grande Basin between the Manzano and Los Pinos Mountains, then trends westward for approximately 30 kilometers $(\mathrm{km})$ over basin alluvium, before reaching the Rio Grande (fig. N1). The arroyo cuts deeply into the alluvium and has a welldefined channel with few tributaries joining it. Although Abo Arroyo is usually a dry streambed, storm-induced streamflow events occur multiple times in a typical year, primarily during the summer monsoon. Quantifying the timing and amount of potential recharge (streambed infiltration) into Abo Arroyo is challenging due to large temporal and spatial variations in streamflow.

\section{Methods}

In this ongoing study, streamflow data and streambed channel properties have been measured in Abo Arroyo since 1996. A U.S. Geological Survey (USGS) streamgage was installed in August 1996, at the upstream end of the study reach, in a region of mountain-front faulting (fig. N-1). The streamflow hydrograph at this streamgage for a 3-year period of record (fig. N-2) shows high variance in flow. We believe this pattern is typical of longterm trends for Abo Arroyo. As a result of high transmission losses into the subsurface along the arroyo, streamflow events rarely reach the confluence of the arroyo and the Rio Grande. Based on the limited period of observation, it is believed that less than 10 streamflow events reach the confluence per year.

Downstream of the streamgage, USGS crest-stage gages (CSG) and surface temperature probes are used to estimate peak streamflows and streamflow duration, respectively. Peak and duration of streamflow are the essential parameters necessary to construct downstream hydrographs. One CSG, located approximately one kilometer down-channel of the streamgage, measures the peak stage of surface water that initially enters the Middle Rio Grande Basin from the mountains. The second CSG, located about $6 \mathrm{~km}$ down-channel of the streamgage (near Highway 47; fig. N-1), measures peak stage at the lower end of the high permeability reach.
We use the temperature-probe procedure of Constantz and others (1999) to determine streamflow duration. In that method, each temperature probe is a thermistor attached to a submersible, single channel data logger, which is buried at approximately 15centimeter depths at specific locations in the arroyo, and temperature is logged at half-hour intervals. The presence of streamflow at a probe location results in a dampening of amplitude in the diurnal temperature signal. The temperature signal "flattens" during streamflow due to smaller diurnal variations in water temperature compared with air temperature at the streambed surface (fig. N-3). Benchmark control probes buried at similar depth on the banks provide background data to assist in calibaration of the temperature records. A comparison of a these probes with the corresponding channel probes aids in determining whether "flattening" of the temperature record results from a streamflow event or an abrupt change in atmospheric conditions.

Surface temperature probes were also used at Abo Arroyo to determine diurnal variation in the distal end of baseflow. Due to evapotranspiration and warming of the stream water, the terminus of the stream changes location throughout a day. Closely spaced surface temperature probes recorded the presence or absence of flow at each of the probe locations. Using temperature as an indicator of streamflow has proved an economical and practical solution in the ungaged reaches of Abo Arroyo. All of the instrumentation, including the recording gage, the crest gages (in operation since mid 1999) and the surface temperature probes (deployed October 1997) will continue operation through at least September 2000.

Basin infiltration experiments have been conducted over the past few years at each surface probe location within the channel. Results indicate that infiltration rates exhibit large variations, both transverse to the streambed channel and longitudinally downchannel. The data identify a region of minimum streambed infiltration in the middle reach of the arroyo west of Highway 47.

Streambed percolation rates through the subsurface are estimated by utilizing heat as a tracer of water movement. Two thermocouple nests (TCN) installed in the channel in the high permeability reach east of Highway 47 recorded temporal variations in the vertical temperature profile during 1997 and 1998. Using an inverse modeling technique similar to Bartolino and Niswonger (1999), percolation rates are computed using the USGS water and energy transport code, VS2DH (Healy and Ronan, 1996).

Hydrologic data collected from Abo Arroyo are used to formulate a conceptual model for ephemeral streamflow that forms 
the basis of a numerical (computer) model to simulate streamflow patterns in arroyos. The computer model will use data collected from Abo Arroyo to calibrate and validate the model for use in predicting patterns of ephemeral-streamflow loss throughout the Southwest.

\section{References}

Bartolino, J.R. and R.G. Niswonger, 1999, Numerical simulation of vertical ground-water flux of the Rio Grande from ground-water temperature profiles, central New Mexico: U.S. Geological Survey Water Resources Investigations Report 99-4212.

Constantz, J., D.A. Stonestrom, A.E. Stewart, R.G. Niswonger, T.R. Smith, 1999, Evaluation of streamflow patterns along seasonal and ephemeral channels by monitoring diurnal variations in streambed temperature. Supplement to EOS, Transactions, AGU, vol. 80, Number 46, F316.

Healy, R.W. and A.D. Ronan (1996). Documentation of computer program VS2DH for simulation of energy transport in variably saturated porous media - Modifications of the U.S. Geological Survey's computer program VS2DT: U.S. Geological Survey Water Resources Investigations Report 96-4230.

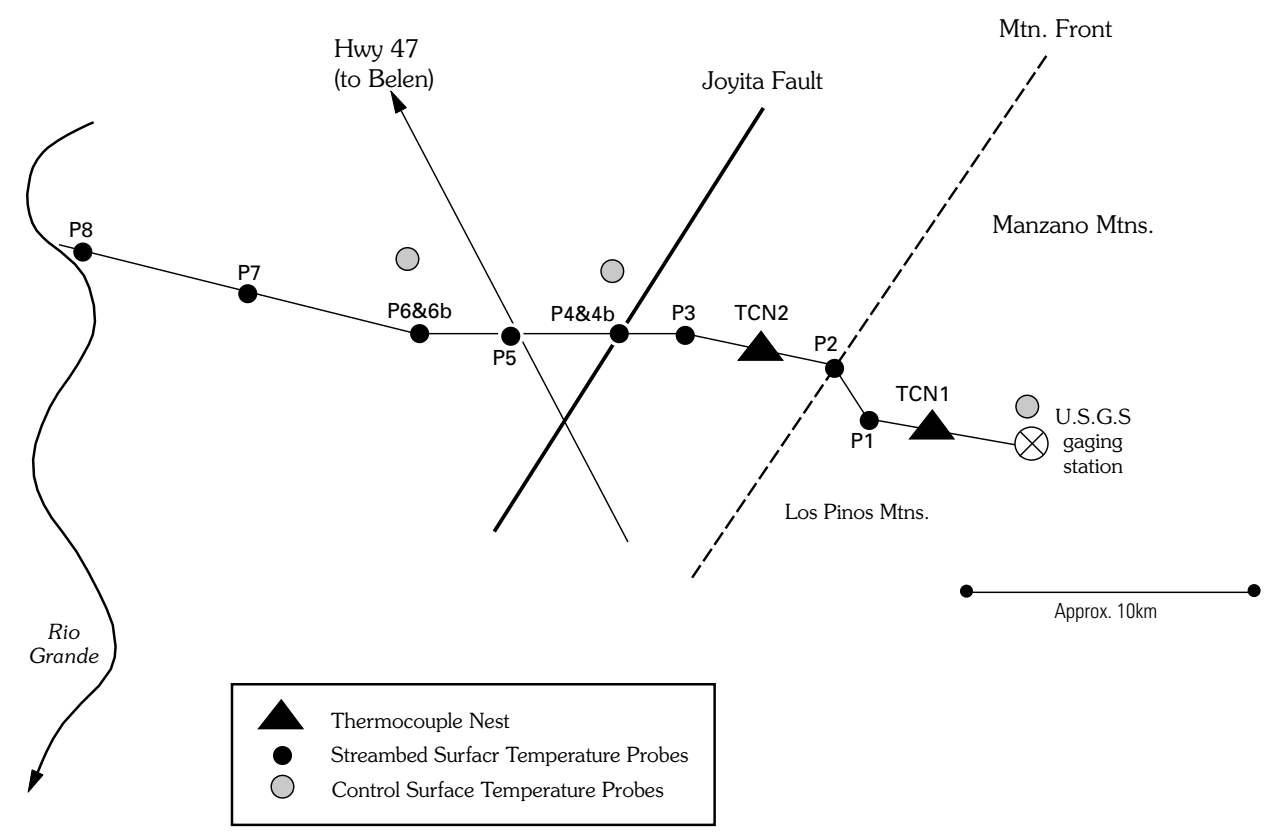

Figure N-1. Site map of Abo Arroyo, New Mexico $\left(34^{\circ} 30^{\prime} \mathrm{N}, 107^{\circ} 30^{\prime} \mathrm{W}\right)$

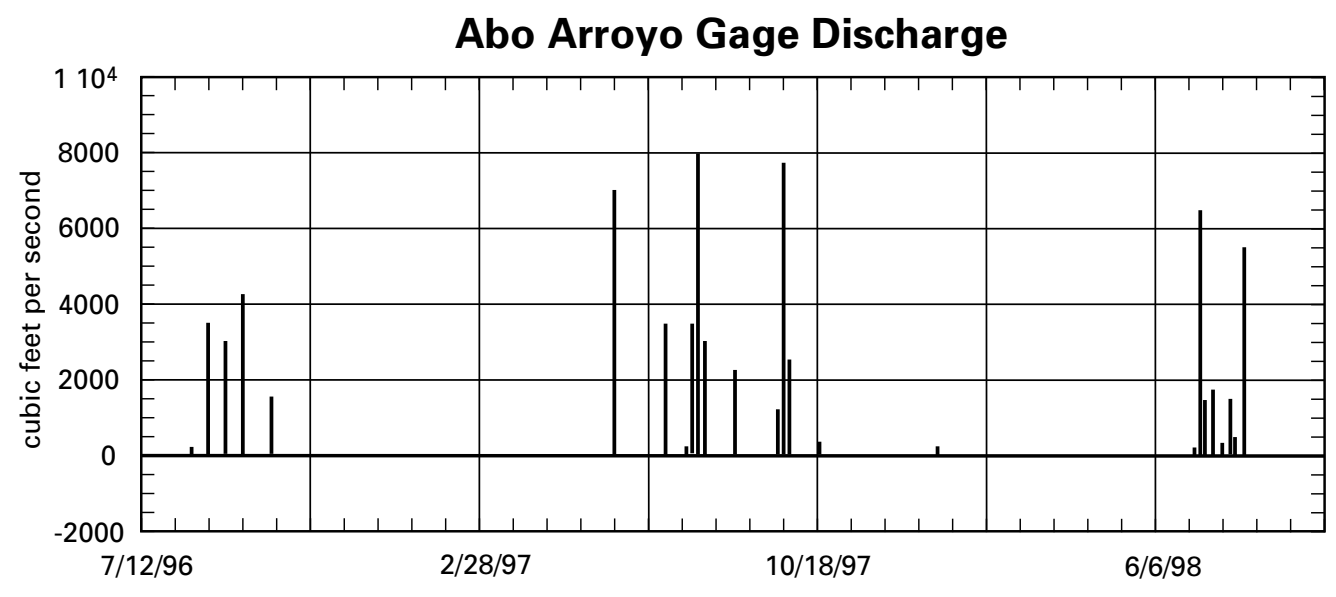

Figure N-2. Hydrographs from the U.S.G.S. gage on Abo Arroyo. Abo Arroyo is an ephemeral stream with streamflows primarily occurring due to rainfall. 


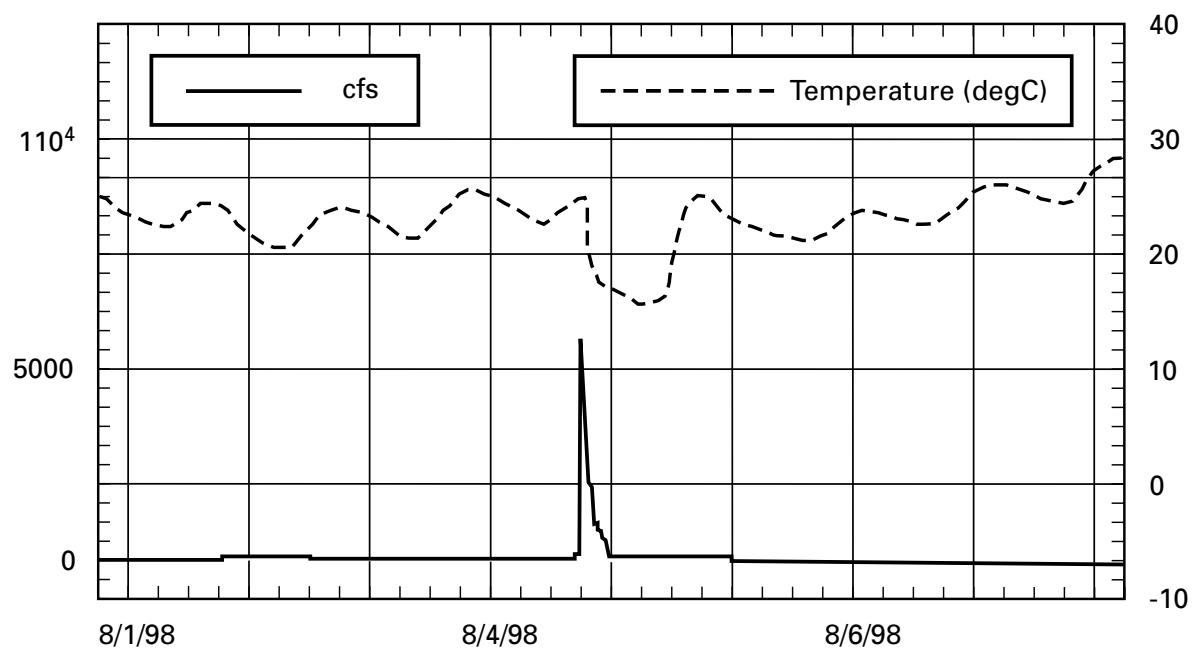

Figure N-3. Thermograph from Abo Probe Site \#3 and Hydrograph from Abo Arroyo gage during a streamflow event on August 4, 1998, Peak surfacewater discharge at the gage was 5700 cfs. The thermograph from surface probe \#3 indicates that streamflow reached that probe. 


\title{
0. Determination of Streamflow Loss to Estimate Mountain-front Recharge at Bear Canyon, New Mexico
}

\author{
Richard Niswonger ${ }^{1,2}$ and Jim Constantz ${ }^{3}$ \\ ${ }^{1}$ U.S. Geological Survey, Carson City NV 89706 and ${ }^{2}$ University of Nevada-Reno \\ ${ }^{3}$ U.S. Geological Survey, Menlo Park CA 94025
}

\section{Introduction}

Mountain-front recharge may be an important component of the total recharge to the aquifer system in the Albuquerque Basin (Bartolino, 1998). Bear Canyon east of Albuquerque is typical of approximately 100 small ephemeral streams that recharge the eastern portion of the basin from the Sandia and Manzano Mountains. These ephemeral streams range in size, but all possess the common characteristics of an upper gaining reach that is bedrockcontrolled, and a lower losing reach that is alluvium-controlled. Various monitoring methods and field reconnaissance were used to estimate streamflow loss and potential recharge along a reach of Bear Canyon (fig. O-1).

\section{Bear Canyon Parameters}

The reach investigated extends from the exposed bedrock at the mountain-front westward for about $3 \mathrm{~km}$. The stream is nonperennial below the mountain front, and rarely flows more than 2 $\mathrm{km}$ from the mountain front due to its limited source and rapid streambed infiltration. Streamflow loss was estimated from measurements of channel geometry, hydraulic gradients, streambed surface temperatures, and vertical temperature profiles.

The average stream width in the perennial section of the stream is about $1.5 \mathrm{~m}$ and the depth is about 15 to $20 \mathrm{~cm}$, based on field measurements along the entire study reach. The channel is not incised beyond the depth of flow and high-water marks were not observed. Stream-bank sediments change from dark sandy soil to sandy coarse gravel downstream from the Bear Canyon bedrock section. In this transition zone, the channel width decreases and the channel becomes more incised. This is especially true $2 \mathrm{~km}$ west of the bedrock area, where the channel is as narrow as $30 \mathrm{~cm}$ but remnant stream banks are preserved as much as $1 \mathrm{~m}$ above the channel bottom.

\section{Results}

Hydraulic gradients were measured with a piezometer at 15 $\mathrm{m}$ intervals along the perennial and seasonal reaches that flowed in April 1999. In the upper reaches where the stream is gaining, Bear Canyon shows a hydraulic gradient ranging between 0.15 and $0.40 \mathrm{~m} / \mathrm{m}$. Downward (negative) unit hydraulic gradients were measured just west of the bedrock section and at three stations down to where flow ceased (fig. O-2).

The amount of recharge from streamflow in Bear Canyon is a function of the length of its losing reach, which is identified as the distance of ephemeral flow west of the bedrock. Estimates of cumulative streambed infiltration require determination of seasonal variations in the extent of the losing reach. Surface temperature probes were installed in Bear Canyon west of the mountain front to monitor the length of the losing reach, using a technique described by Constantz and others (1999). These probes provide data on the seasonal variation of streamflow extent 1998 and 1999 (fig. O-3). Temperature probe results suggest that no streamflow events were sufficient to maintain streamflow more than $2 \mathrm{~km}$ beyond the mountain front. During the monitoring period, flow persisted $125 \mathrm{~m}$ beyond the mountain front (west of probe 3 ) between 11/6/98 to 6/16/99. Flow persisted $210 \mathrm{~m}$ beyond the mountain front (west of probe 4 ) from 4/27/99 to 7/2/ 99. Flow failed to reach $300 \mathrm{~m}$ beyond the mountain front (west of probe 5).

Streambed percolation rates were estimated at two locations by the heat tracer method (Constantz and others, 1999). Vertical thermocouple nests were installed between 40 and $300 \mathrm{~cm}$ below the streambed in locations about 1 and $1.5 \mathrm{~km}$ west of the mountain front. A variably saturated heat- and groundwater-flow model, VS2DH (Healy and Ronan, 1996), was used to predict streambed water fluxes by simulating the amount of heat advection required to match measured sediment temperatures.

A model-independent parameter estimation technique was used to determine the streambed sediment hydraulic conductivity from the best fit between the simulated and measured sediment temperatures.

Thermal parameters for Bear Canyon sediments at residual moisture content were determined by matching the sediment temperatures when flow was absent, thereby simulating heat conduction in the absence of stream infiltration. Figure 4 shows sediment temperatures at various depths below the streambed. The simulated/optimized sediment temperatures at 60 $\mathrm{cm}$ are also shown. An average streambed flux of $75.5 \mathrm{~cm} /$ day resulted from these simulations. Streamflow occurred for about 50 days at this location. Confidence in flux estimates and analysis of variance in water flux with respect to errors in hydraulic parameters were determined using Monte Carlo analysis. Variance in flux estimates was calculated from uncertainties in thermal parameters, dispersivities, and measurement errors in temperature.

We plan to use recharge results for the study reach at Bear Canyon as the basis for a general estimate of mountain-front recharge from the Sandia and Manzano Mountains during the study period. The relative contribution of mountain-front recharge as a component of total basin recharge can then be estimated for the basin. 


\section{Acknowledgement}

The authors would like to thank Angus Lewis (Gannett Fleming Inc., Madison WI) for collaboration in the field.

\section{References}

Bartolino, J. R., 1998, Temperature profiles of the aquifer system underlying the Rio Grande, Middle Rio Grande Basin, New Mexico-Second Year Status: Proceedings of the Second Annual Workshop,
Albuquerque, New Mexico, February 10-11, 1998: U.S. Geological Survey Open-File Report 98-337, pp. 50-52.

Constantz, Jim, D. A. Stonestrom, A.E. Stewart, R.G. Niswonger, T. R. Smith, 1999, Evaluating streamflow patterns along seasonal and ephemeral channels by monitoring diurnal variations in streambed temperature: Supplement to EOS, Transactions, AGU, Vol. 80, Number 46, p. F316.

Healy, R. W., and Ronan, A. D., 1996, Documentation of the computer program VS2DH for simulation of energy transport in variably saturated porous media -- Modification of the U.S. Geological Survey's computer program VS2DT: U.S. Geological Survey Water-Resources Investigation Report 96-4230, 36 p.

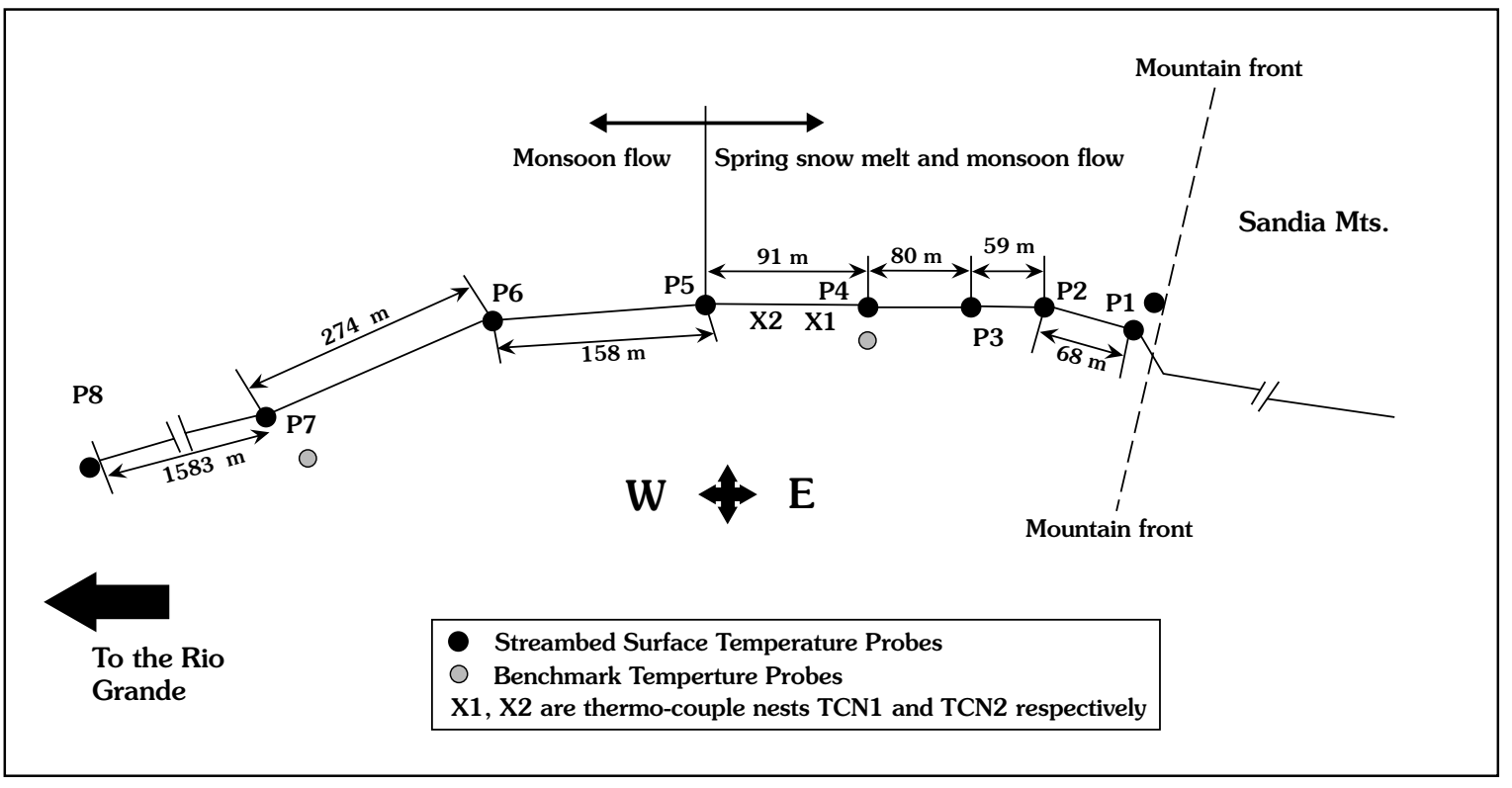

Figure 0-1. Map of Bear Canyon with surface probe locations.

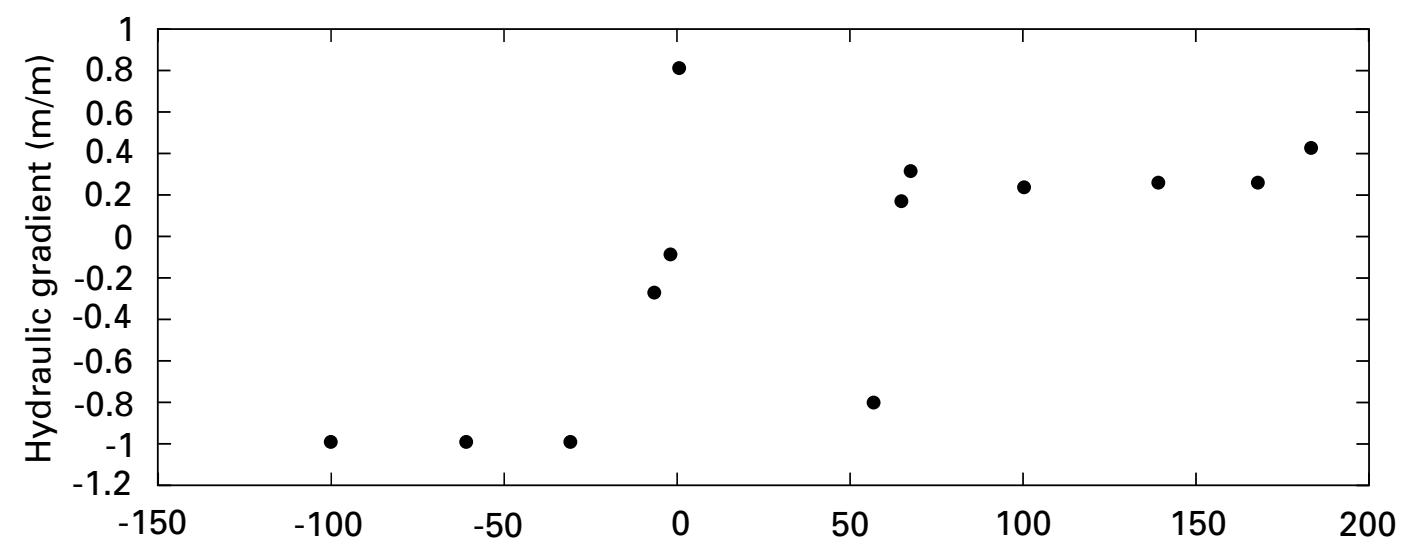

Distance from mountain front negative to the west (m)

Figure 0-2. Hydraulic gradients measured in Bear Canyon. A positive gradient indicates groundwater discharge. 

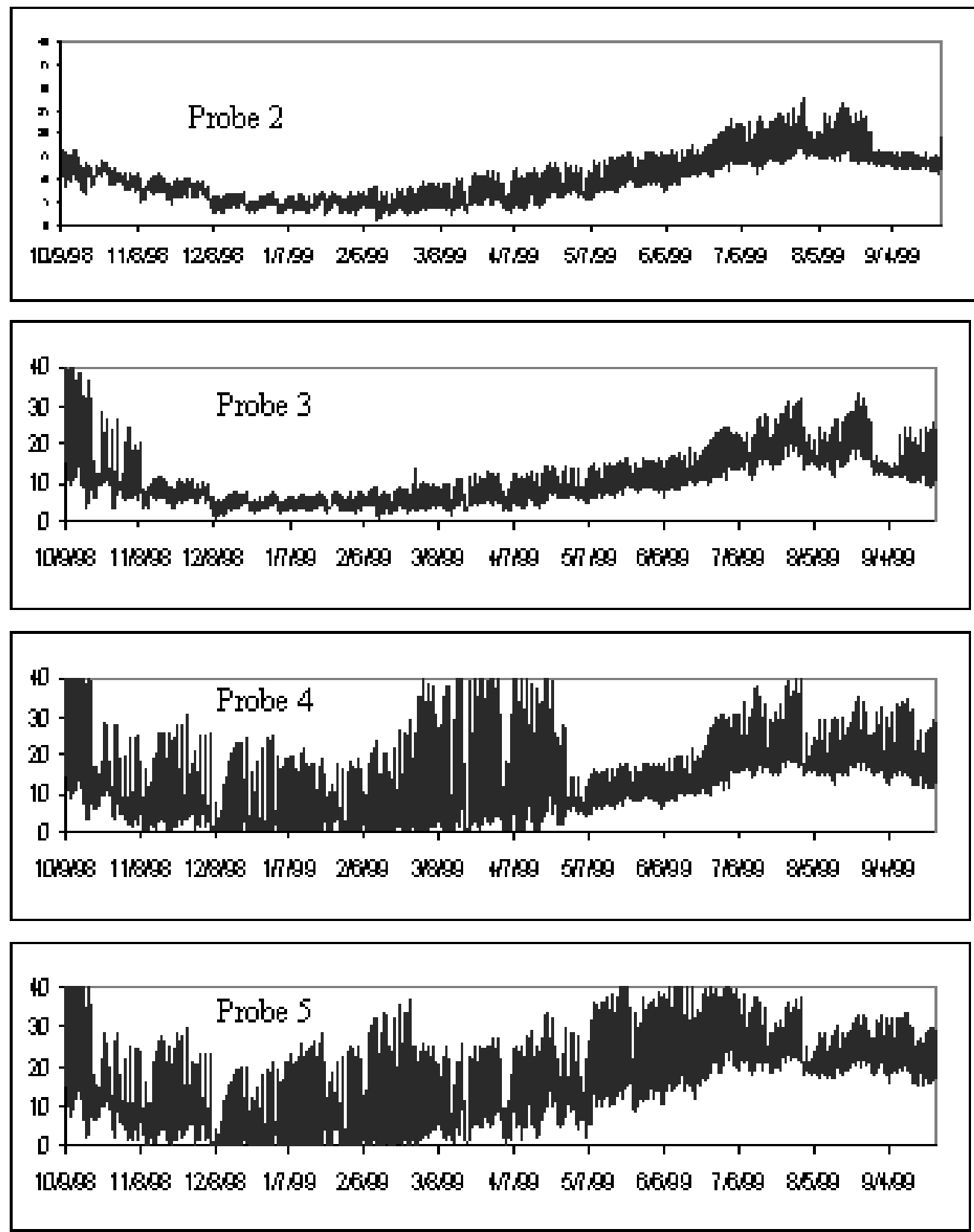

Figure 0-3. Plots of surface temperatures for probe sites two through five.

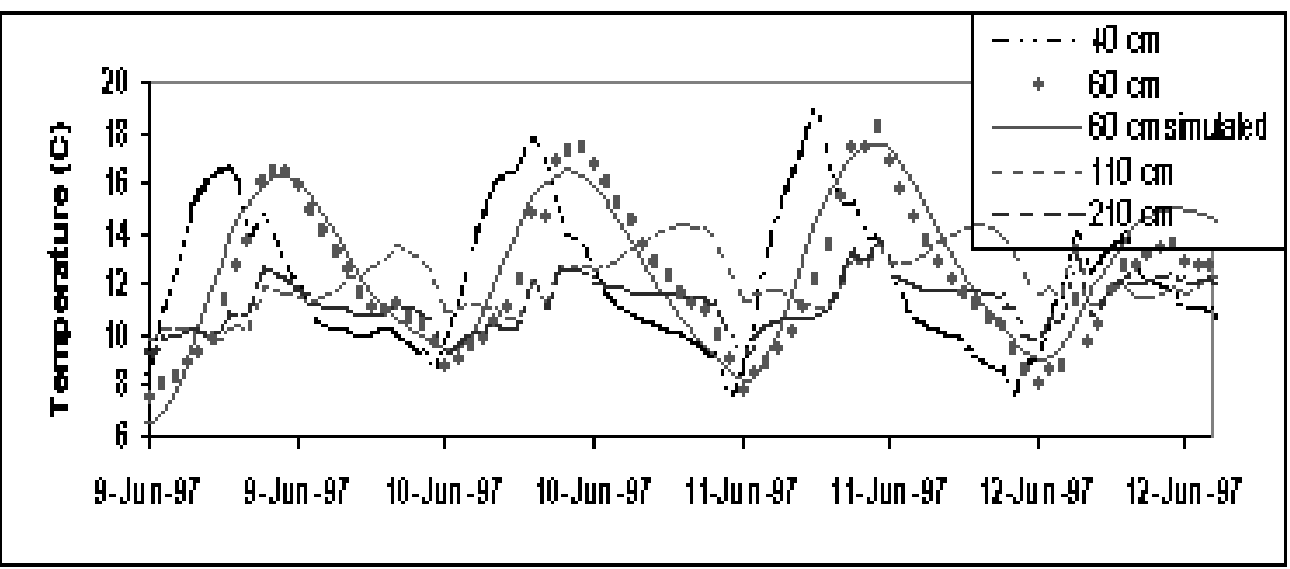

Figure 0-4. Sediment temperatures in Bear Canyon at TCN1 (275 m west of mountain front) when stream-flow was present. 


\title{
P. Discernable Large-and Small-scale Features Affecting Recharge in Abo Arroyo and Similar Basins
}

\author{
John R. Nimmo ${ }^{1}$, Angus M. Lewis ${ }^{2}$, and Kari A. Winfield ${ }^{1}$ \\ ${ }^{1}$ U.S. Geological Survey, MS 421, Menlo Park CA 94025 \\ ${ }^{2}$ Gannett Fleming, Inc., Madison WI 53717
}

\section{Introduction and Methods}

Darcy's law can be used to provide a high-quality estimate of recharge rate at field sites where surface materials are core-sampled. The technique requires an accurate measurement of unsaturated hydraulic conductivity $(\mathrm{K})$, field-water-content of a core sample, and knowledge of the driving force for water flow at the sample site. In this study, we used the steady-state centrifuge (SSC) method (Nimmo and others, 1994) to measure K. The combined procedure for obtaining recharge estimates is referred to as the Darcian-SSC method.

\section{Results}

We use the 16 Darcian-SSC point recharge estimates of Lewis and others (1999), with additional geologic observations, to estimate the total recharge rate for the reach of Abo Arroyo and its adjacent terraces between the basin margin and the Rio Grande.

In the streambed, recharge rate estimates in terms of flux density or Darcy velocity (q) range from 0.1 to $2,700 \mathrm{~cm} / \mathrm{yr}$ at six locations (fig. P-1). Samples taken from the upper reach, where streamflow persists much of the year, give q estimates of 2,000 to $2,700 \mathrm{~cm} / \mathrm{yr}$, with the exception of one $0.15 \mathrm{~cm} / \mathrm{yr}$ value considered to be anomalous as explained by Lewis and others (1999). Approximately $12 \mathrm{~km}$ down-channel, q is $150 \mathrm{~cm} / \mathrm{yr}$, and roughly $8 \mathrm{~km}$ farther down-channel $\mathrm{q}$ is $3 \mathrm{~cm} / \mathrm{yr}$. These numbers suggest recharge decreases markedly downstream. Recharge increases at the site $28 \mathrm{~km}$ down-channel to nearly $1,900 \mathrm{~cm} / \mathrm{yr}$ near the confluence of Abo Arroyo and the Rio Grande, within the modern floodplain of the river (Lewis and others, 1999).

Samples taken on the terrace 4 to $460 \mathrm{~m}$ away from the arroyo give q estimates of less than $0.015 \mathrm{~cm} / \mathrm{yr}$. These low values are consistent with the areally diffuse recharge typical of interarroyo regions. Assuming they are representative over the entire interarroyo area, a recharge rate of $0.015 \mathrm{~cm} / \mathrm{yr}$ applied over the entire Middle Rio Grande Basin $\left(8,000 \mathrm{~km}^{2}\right)$ results in a total inter-arroyo recharge estimate of 970 acre-ft/yr.

We interpret that Abo Arroyo flows through three distinct geologic settings between the basin margin and the Rio Grande, based on analysis of topographic maps, aerial photos, field notes, and previous studies of the site geology (Spiegel, 1955; Titus, 1963; Machette, 1978). Within these settings we consider the segments of Abo Arroyo as subregions within which local recharge rates are systematically related (fig. P-2).
The first recharge subregion, a 1-km segment of the arroyo near the river, is the active floodplain of the Rio Grande. The sediments here are well-sorted loose sands, which may allow rapid infiltration. Large erosional features at the margin of the active floodplain suggest inflow from tributaries at this location. Irrigation and a relatively shallow water table may also influence estimated recharge. We assume the high $(2000 \mathrm{~cm} / \mathrm{yr})$ recharge estimate applies for this $1-\mathrm{km}$ segment.

The second subregion comprises ancestral fluvial terraces of the Rio Grande. This area extends eastward about 15 kilometers from the margin of the active floodplain. The surface sediments are well sorted and sandy; however, in contrast to the loose sediments in the active floodplain subregion, a hard surface crust exists that may reduce infiltration. The recharge rate of $3 \mathrm{~cm} / \mathrm{yr}$ is assumed to apply for the subregion as a whole.

The third subregion is the piedmont slope, consisting of alluvial fan deposits that extend $12 \mathrm{~km}$ westward from the basin margin. Recharge estimates are about 2,000 cm/yr near the mountain front and $150 \mathrm{~cm} / \mathrm{yr}$ at a site $12 \mathrm{~km}$ down-channel. Surface sediments here are primarily sands and gravels. Both largest particle size and slope of the piedmont surface decrease rapidly with down-channel distance. This suggests that the decrease in flow with distance from the mountains is likely to be exponential rather than linear (Allen Gellis, U.S. Geological Survey, personal commun.).

An exponential fit to the point estimates yields a formula for recharge rate as a function of position along the channel, which can be integrated over the length of the subregion. Multiplying by the effective channel width provides the estimation of recharge for the subregion. Decreasing recharge rates along the channel are consistent with infiltration-rate measurements that suggest declining hydraulic conductivity down-channel, except for the marked increase in the modern floodplain within $1 \mathrm{~km}$ of the Rio Grande (Stewart and Constantz, 1999).

We have computed total recharge for each of the three subregions, based on these data and assumptions, and taking the effective channel width to be $15 \mathrm{~m}$. This width value is somewhat greater than typically observed for the surface active channel (10 $\mathrm{m})$ to allow for subsurface lateral spreading of the infiltration. The resulting estimates are $240 \mathrm{acre}-\mathrm{ft} / \mathrm{yr}$ for the Rio Grande floodplain, 5 acre-ft/yr for the Rio Grande terraces, and 1040 acre-ft/yr for the piedmont slope. The estimated total recharge for the region of Abo Arroyo between the mountain front and the Rio Grande is then approximately 1,300 acre-ft/yr. This value is in reasonable agreement with an estimate based on the chloride-balance method of 1,280 acre-ft/yr for the Abo Arroyo mountain-drainage basin (Anderholm, 2000). 
Inferred Flux Densities of Abo Arroyo

$\downarrow$ (proportional to flux density, $\mathrm{q}$, in $\mathrm{cm} / \mathrm{yr}$ )

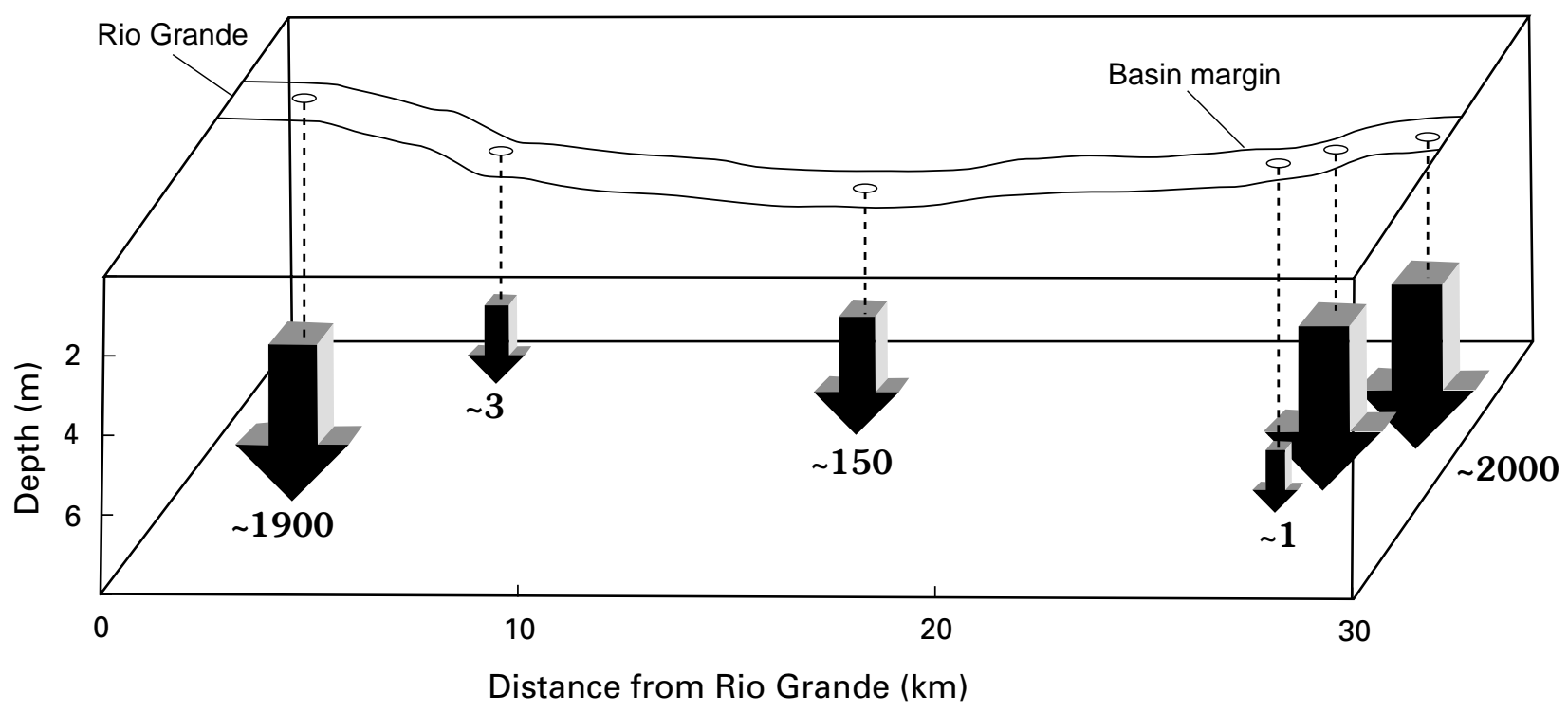

Figure P-1. Darcian-SSC recharge estimates in the channel of Abo Arroyo.

\section{Recharge Subregions of Abo Arryo}

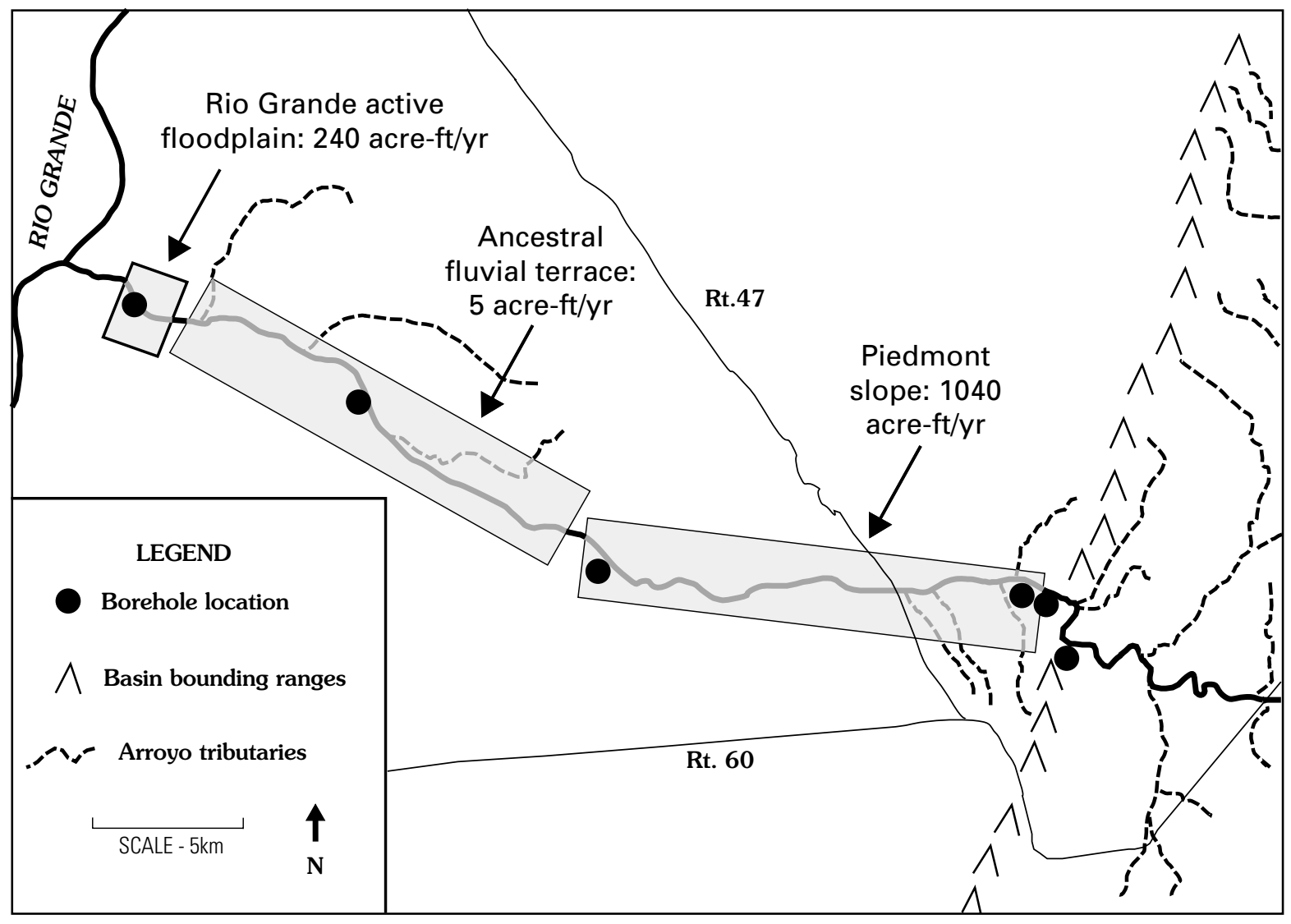

Figure P-2. Recharge subregions of Abo Arroyo. 
Our approach primarily relates the geologic nature of unsaturated-zone materials to recharge rate. Related studies (for example Stewart and Constantz, 1999) assess such variables as frequency of streamflow and maximum infiltration. Further investigations are needed concerning interarroyo recharge, additional recharge from tributaries on the Rio Grande floodplain, and the assumed effective channel width. Significant recharge may occur along the mountain front, but outside of the arroyo. We have assumed this source is negligible, but the surface and subsurface processes associated with it are not fully understood. Correlation of recharge rate with topography, vegetation, and other factors needs to be investigated in order to produce reliable recharge estimates based on properties and conditions that are easy to observe and measure.

\section{References}

Anderholm, S.K., 2000, Mountain-front recharge along the eastern side of the Middle Rio Grande Basin, central New Mexico: U.S. Geological Survey Water-Resources Investigations Report 00-4010, 36 p.

Lewis, A.M., Nimmo, J.R., and Stonestrom, D.A., 1999, Recharge estimates interpreted from centrifuge hydraulic property measurements of core samples from Abo Arroyo, Middle Rio Grande Basin, New Mexico, in Bartolino, J.R., ed., 1999, U.S. Geological Survey Middle Rio Grande Basin Study--Proceedings of the Third Annual Workshop, Albuquerque, New Mexico, February 24-25, 1999: U.S. Geological Survey Open-File Report 99-203, p. 69-70.

Machette, M.N., 1978, Preliminary geologic map of the Socorro $1^{\circ}$ by $2^{\circ}$ quadrangle, central New Mexico: U.S. Geological Survey Open-file Report 78-607.

Nimmo, J.R., Stonestrom, D.A., and Akstin, K.C., 1994, The feasibility of recharge rate measurements using the steady-state centrifuge method: Soil Science Society of America Journal, v. 58, no. 1, p. 4956.

Spiegel, Z.E., 1955, Geology and ground-water resources of northeastern Socorro County, New Mexico: New Mexico Bureau of Mines and Mineral Resources Ground Water Report 4, $99 \mathrm{p}$.

Stewart, A.E. and Constantz, J., 1999, Developing a long-term water balance for Abo Arroyo, New Mexico, in Bartolino, J.R., ed., 1999, U.S. Geological Survey Middle Rio Grande Basin Study--Proceedings of the Third Annual Workshop, Albuquerque, New Mexico, February 24-25, 1999: U.S. Geological Survey Open-File Report 99-203, p. 73-74.

Titus, F.B., Jr., 1963, Geology and ground-water conditions in eastern Valencia County, New Mexico: New Mexico Bureau of Mines and Mineral Resources Ground-Water Report 7, $113 \mathrm{p}$. 


\title{
0. Hydrogeothermal Studies in the Albuquerque Basin- Preliminary Results
}

\author{
Marshall Reiter \\ New Mexico Bureau of Mines and Mineral Resources, New Mexico Tech, Socorro NM 87801
}

\section{Introduction}

As part of a cooperative study, precision temperature logs have been made at twenty-two piezometer sites within the Albuquerque Basin. Approximately eight additional sites will be measured in the future. These piezometers were sponsored by the City of Albuquerque, Bernalillo County, New Mexico State Engineer Office, U.S. Geological Survey, and several Pueblos in the area.

\section{Methods}

Piezometer depth varies from about $150 \mathrm{~m}$ to about $500 \mathrm{~m}$; vadose zone depth at the piezometers varies from a meter or so near the Rio Grande to about $250 \mathrm{~m}$ at the higher elevation sites 10 to $15 \mathrm{~km}$ from the river. The data were taken in a continuous logging mode using four-conductor thermistor-resistance technology much like that described in Reiter and others (1980). The analysis uses data taken in water below $20 \mathrm{~m}$ depth to avoid seasonal temperature swings. The temperature logs are used to estimate groundwater flow as described in Bredehoeft and Papadopulos (1965), Mansure and Reiter (1979), and McCord and others (1992).

\section{Results}

Several preliminary observations can be made from the data. (1) At sites near the Rio Grande, horizontal groundwater flows (Darcy velocities) of several meters per year (m/yr) to a hundred $\mathrm{m} / \mathrm{yr}$ and more are estimated at relatively shallow depths $(100 \mathrm{~m}$ or less). The shallow vertical groundwater flow at one site is calculated to be about $0.6 \mathrm{~m} / \mathrm{yr}$. At greater depths (exceeding 100 $\mathrm{m})$ the horizontal flows are estimated to range from several tenths of a $\mathrm{m} / \mathrm{yr}$ to several $\mathrm{m} / \mathrm{yr}$, and at some sites perhaps $10 \mathrm{~m} / \mathrm{yr}$. The deeper vertical flow at some sites is estimated to be about several hundredths of a m/yr. (2) Away from the river at sites within and bordering the flood plain, horizontal groundwater flows of several tenths of a m/yr to several tens of $\mathrm{m} / \mathrm{yr}$ are estimated to depths of about $300 \mathrm{~m}$. Vertical flow at some of these sites is estimated as several hundredths to several tenths of a m/yr. Horizontal flow at some of these sites was either undetectable or less than about 0.5 $\mathrm{m} / \mathrm{yr}$ below 200-300 $\mathrm{m}$ depth. (3) Groundwater flow in the Tijeras Arroyo is very dynamic and appears most substantial along relatively thin depth zones that are located preferentially in the upper several hundred meters. (4) Horizontal flows were either undetectable or less than 1 or $2 \mathrm{~m} / \mathrm{yr}$ over the entire well depth at five sites located 5 to $15 \mathrm{~km}$ away from the Rio Grande.

\section{References}

Bredehoeft, J. D. and Papadopulos, I. S., 1965, Rates of vertical groundwater movement estimated from the earth's thermal profile: Water Resources Research, v. 1, p. 325-328.

Mansure, A. J., and Reiter, M., 1979, A vertical ground-water movement correction for heat flow: Journal of Geophysical Research, v. 84, p. 3490-3496.

McCord, J., Reiter, M., and Phillips, F., 1992, Heat flow data suggest large ground-water fluxes through Fruitland coals of the northern San Juan Basin, Colorado-New Mexico: Geology, v. 20, p. 419-422.

Reiter, M., Mansure, A. J., and Peterson, B. K., 1980, Precision continuous temperature logging and correlations with other types of logs: Geophysics, v. 45, p. 11857-11868. 


\title{
RELATED STUDIES IN THE MIDDLE RIO GRANDE BASIN AND VICINITY
}

\section{R. Mineralogical and Geochemical Constraints on Fe and As Residence and Mobility in the Albuquerque Basin: Examples from Basin Sediments and Volcanic Rocks}

\author{
Mark R. Stanton, Richard F. Sanzolone, Stephen J. Sutley, David J. Grimes, \\ and Allen M. Meier \\ U.S. Geological Survey, MS 964, Denver C0 80225
}

\section{Introduction}

We report on geochemical studies of iron $(\mathrm{Fe})$ and arsenic (As) in the ground water system of the Albuquerque Basin. Our work examines the mineralogical residence of these elements (where they occur) and the geochemical factors that influence their mobility in ground water. The Fe and As detected in ground water are believed to arise from geochemical exchange with the aquifer rock materials. High concentrations of these two elements in ground water, particularly As, constitute water-quality issues for the area. We analyzed sediment and rock samples obtained from three wells in the basin; the 98th Street well, the Shell Isleta \#2 well, and the Kachina well.

\section{Sediment Mineralogy and Elemental Concentration}

In the 98th Street well, Santa Fe Group (SFG) sediments contain on average $8.5 \mathrm{ppm}$ total arsenic; mineralogy is dominated by quartz, feldspar (albite, sanidine), muscovite, and clay (illite, smectite) minerals, and mixed-metal ( $\mathrm{Fe}, \mathrm{Al}, \mathrm{Mn})$ oxides produced by weathering. These mixed-metal oxides are dominated by Fe-oxides. In the Shell Isleta \#2 well, SFG sediments contain less total As (average $=5.9 \mathrm{ppm}$ ) but mineralogy is similar to 98 th Street. SFG sediments from the upper part of the Kachina well are comparable to the 98th Street and Shell Isleta \#2 wells (average As=18 ppm), but mafic-to-intermediate volcanic rocks are present in Kachina below approximately $1900 \mathrm{ft}$. Arsenic in these volcanic materials averages $290 \mathrm{ppm}$ and mineralogy is dominated by feldspars and pyrite, with lower abundances (less than 10 volume percent) of mixed-metal oxides. The lower Kachina samples, although not part of the SFG sediment section, represent a potential source of Fe and As elsewhere in the basin.

\section{Residence and Mobility of Fe and As}

We subjected samples of SFG sediment to various reagents that mimic weathering and alteration processes, in order to evaluate the mobility of iron and arsenic under differing conditions. This five-step, sequential, partial-extraction technique (initially developed to study selenium mode of occurrence elsewhere; Chao and Sanzolone, 1989) provides information about what kinds of minerals and compounds contain the solid phase $\mathrm{Fe}$ and As in the sediment. The extracting reagents (listed below in parentheses) are capable of liberating $\mathrm{Fe}$ and As from various types of compounds. The step-wise technique produces five operationally-defined fractions that reflect different residence sites of $\mathrm{Fe}$ and $\mathrm{As}$ in the sediments. These fractions are listed in order of decreasing mobility of As (increasing difficulty of extraction): A) water-soluble or water-exchangeable As ( 0.25 $\mathrm{M} \mathrm{KCl}$ ); B) ligand- or anion-exchangeable As (0.1 $\left.\mathrm{M} \mathrm{KH}_{2} \mathrm{PO}_{4}\right)$; C) acid-extractable As in mixed-metal oxides (4M HCl); D) oxidative acid-decomposable As in sulfide minerals/complex organic compounds $\left(\mathrm{KClO}_{3}+\right.$ concentrated $\left.\mathrm{HCl}\right)$; and E) strong mixed-acid digestable As, primarily in silicate minerals ( $\mathrm{HF}+$ $\mathrm{HNO}_{3}+\mathrm{HClO}_{4}$ ). Concentrations of $\mathrm{Fe}$, As, and other elements in the extract solutions were determined by inductively coupledplasma mass spectrometry.

SFG samples from the 98th Street well showed no detectable As $(<0.05 \mathrm{ppm})$ in the water-soluble extraction; As concentrations were $\leq 2.2 \mathrm{ppm}$ in the anion-exchangeable fraction. About $40 \%$ to $90 \%$ of total arsenic in SFG sediments is contained in the acid-extractable mixed-metal oxides. Arsenic also resides in the sulfide/organic ( $\leq 1 \mathrm{ppm})$ and silicate ( $\leq 2 \mathrm{ppm})$ fractions. Iron was not detected in the water-soluble extraction, and only 2 samples had detectable anion-exchangeable $\mathrm{Fe}$. Fe has nearly equal proportions (30\% to 50\%) residing in the metaloxide and silicate fractions, with a small additional percentage $(\leq 10 \%)$ attributed to the sulfide/organic fraction. In contrast to SFG sediments, Fe and As in the volcanic rocks of the lower Kachina-well section are associated predominantly with the sulfide (pyrite) fraction.

Arsenic may be mobilized from metal oxides by changes to higher $\mathrm{pH}$ or lower redox potential (Eh), although Fe-oxides are increasingly stable and dissolve slowly at higher $\mathrm{pH}$ and Eh values. City production wells have $\mathrm{pH}$ values ranging from 7.2 to 8.7. Ground waters from the 98th Street well have slightly higher $\mathrm{pH}$ (8.6-9.1) that may aid in mobilizing As. 
In addition, As species determined by an ion-exchange method (Ficklin, 1982) show the dominant oxidation state of As in nearly all Albuquerque production wells is $\mathrm{As}^{5+}$. In two 98th Street water samples, however, high proportions of reduced $\mathrm{As}^{3+}$ relative to oxidized $\mathrm{As}^{5+}\left(31 \mathrm{ppm} \mathrm{As}^{3+}\right.$ vs $4 \mathrm{ppm} \mathrm{As}^{5+}$, and $8 \mathrm{ppm}$ $\mathrm{As}^{3+} \mathrm{vs}<2 \mathrm{ppm} \mathrm{As}^{5+}$ ) indicate reducing conditions, which result in increased As mobilization.

The extraction and mineralogical results suggest metaloxides (primarily Fe) are major sources and sinks of Fe and As (and other trace elements) in SFG sediments. The data also suggest that arsenic in Santa Fe Group sediments near Albuquerque may be mobilized by interaction of As-bearing Fe-oxides with ground water having higher $\mathrm{pH}$ and/or lower Eh.

\section{References}

Chao, T.T., and Sanzolone, R.F., 1989, Fractionation of soil selenium by sequential partial dissolution. Soil Science Society of America Journal, v. 53, p. 385-392.

Ficklin, W.H., 1982, Separation of $A s(I I I)$ and $A s(V)$ in ground waters by ion-exchange. Talanta, v. 30, p.371-373.

\title{
S. Comparison of Geomorphic and Isotopic Measurements for Erosion in the Rio Puerco, New Mexico
}

\author{
Allen Gellis ${ }^{1}$, Milan Pavich ${ }^{2}$, Paul Bierman ${ }^{3}$, Amy Ellwein ${ }^{4}$, Scott Aby ${ }^{5}$, and Erik Clapp ${ }^{3}$ \\ ${ }^{1}$ U.S. Geological Survey, 5338 Montgomery Blvd NE, Albuquerque NM 87109 \\ ${ }^{2}$ U.S. Geological Survey, 12201 Sunrise Valley Dr., MS 908, Reston VA 20192 \\ ${ }^{3}$ Dept. of Geology, University of Vermont, Burlington VT 05401 \\ ${ }^{4} 26210$ Rimwick Forest Drive, Magnolia Drive TX 77354 \\ ${ }^{5}$ Dixon NM
}

\section{Introduction}

The Rio Puerco basin $\left(16,100 \mathrm{~km}^{2}\right)$ is the largest tributary to the Rio Grande in New Mexico, and drains more than 20 percent of the Rio Grande basin area above the gaging station at San Marcial (south of Socorro). The Rio Puerco contributes only 4 percent of the Rio Grande's average annual runoff at San Marcial but over 70 percent of the Rio Grande's average annual suspended-sediment load. Using data compiled for world rivers by Milliman and Meade (1983) and Zhao and others (1992), the Rio Puerco has the fourth highest average annual suspended-sediment concentration and is therefore, a world-class river in terms of erosion and sediment transport. Only two stations on the Yellow River, China, and the Sanchuanhe River, a tributary to the Yellow River, have higher concentrations.

\section{Methods}

Erosion (surface lowering by sediment removal) in the Rio Puerco basin was measured for two different time scales: the modern time scale using process-geomorphic techniques and the geologic time scale using cosmogenic isotope dating. At the modern time scale (1 to 4 years), surface lowering by erosion was measured using sediment traps (Gerlach troughs; Gerlach,1967) and sediment accumulation behind small dams. The Gerlach troughs are $70 \mathrm{~cm} \times 40 \mathrm{~cm} \times 13 \mathrm{~cm}$ plastic traps that measure runoff and sediment during rainfall events. Dams were constructed of straw bales in first and second-order channels. Using these techniques, we were able to measure sediment accumulation from contributing areas that ranged over several orders-of-magnitude (Gerlach troughs, 0.84 to $37 \mathrm{~m}^{2}$; straw-bale dams, 245 to $2,276 \mathrm{~m}^{2}$ ), which permitted analysis of the effect of drainage area on sediment yields. Surface lowering by erosion over geologic time scales $\left(>10^{6}\right.$ years) was measured using the cosmogenic radionuclides ${ }^{10} \mathrm{Be}$ and ${ }^{26} \mathrm{Al}$ that are produced in-situ as surface materials are exposed to cosmic rays. Cosmogenic radionuclide abundances in near-surface $(<1 \mathrm{~m})$ quartz provide a measure of the exposure and erosion history of sand grains moving through a basin. In low erosion areas, sediment at the Earth's surface accumulates a high abundance of radionuclides. Conversely, in high erosion areas the abundance of radionuclides in the sediment is low.

The different methods for quantifying erosion rates were compared in the Arroyo Chavez subbasin $\left(2.21 \mathrm{~km}^{2}\right)$ of the Rio Puerco. Ten sediment traps were installed and cosmogenic radionuclide samples were collected along four geomorphic surfaces: mesa top, colluvial slope, alluvial fan, and the alluvial valley floor. Straw-bale dams were constructed in four channels draining the mesa top, colluvial slopes, and the alluvial valley floor.

\section{Results}

Four monsoonal cycles were monitored in Arroyo Chavez between August 1995 and October 1998. Average erosion rates for each geomorphic element were: mesa $0.30 \mathrm{~mm} / \mathrm{yr}$, colluvial slope $0.25 \mathrm{~mm} / \mathrm{yr}$, alluvial fan $0.37 \mathrm{~mm} / \mathrm{yr}$, and the alluvial valley floor $2.90 \mathrm{~mm} / \mathrm{yr}$. Cosmogenic radionuclide data indicate the 
basin-wide erosion rate is $100+/-25 \mathrm{~m} / \mathrm{Myr}(0.10 \mathrm{~mm} / \mathrm{yr})$.

Results of this study indicate the mesa, colluvial slope, and alluvial fan environments have experienced similar erosion rates for the modern time scale (using geomorphic techniques) and for the geologic time scale (using cosmogenic radionuclide abun-

dances). The higher erosion rates measured with the geomorphic techniques on the alluvial valley floor over the modern time scale may possibly show effects of livestock grazing and gas-pipeline activities that are more commonplace on the valley floor.

\section{References}

Gerlach, T., 1967, Hillslope troughs for measuring sediment movement: Revue Geomorphologie Dynamique, v.4, p.173.

Milliman, J.D. and Meade, R.H., 1983, World-wide delivery of river sediment to the oceans: Journal of Geology, v.91, p.1-21.

Zhao, W., Jiao, E., Wang, G., and Meng, X., 1992, Analysis of the variation of sediment yield in Sanchuanhe River basin in 1980's: International Journal of Sediment Research, v.7, p. 1-20.

\title{
T. Surface Geology and Liquefaction Susceptibility in the Inner Rio Grande Valley Near Albuquerque, New Mexico
}

\author{
Keith I. Kelson, Christopher S. Hitchcock, and Carolyn E. Randolph \\ William Lettis \& Associates, Inc., 1777 Botelho Drive, Walnut Creek CA 94596
}

\section{Introduction}

Historic large earthquakes throughout the world demonstrate that liquefaction-related ground failure commonly causes extensive damage in urbanized areas to structures and essential lifeline facilities. Delineating areas that are susceptible to liquefaction is critical for evaluating and reducing the risk from liquefaction through appropriate mitigation and emergency response.

Liquefaction generally occurs in areas underlain by low-density, saturated granular sediments, and so liquefaction susceptibility can be mapped using specific, well established geologic and geotechnical criteria. The inner Rio Grande valley near Albuquerque is within the seismically active Rio Grande rift, is underlain by saturated late Holocene floodplain deposits, and thus is particularly vulnerable to liquefaction hazards. The purpose of this study has been to delineate areas of the inner Rio Grande valley near Albuquerque that are susceptible to liquefaction (Kelson and others, 1999). The map products developed in the study are useful for insurers, engineers, planners, and emergency-response personnel in order to properly assess and mitigate the risk from future liquefaction.

\section{Methods}

Our approach has been to identify geologic units that are susceptible to liquefaction and to delineate their extents based on surficial geologic mapping and analysis of subsurface geotechnical data, in relation to areas of shallow groundwater. Kelson and others (1999) present several 1:24,000-scale maps of the inner valley that depict: (1) surficial geologic units, (2) depth to groundwater, and (3) liquefaction susceptibility. The map area covers the inner Rio Grande valley from the Jemez River on the north to the Isleta Pueblo on the south, and includes parts of the Bernalillo, Alameda, Los Griegos, Albuquerque West, and Isleta 7.5-minute quadrangles. The geologic maps of the inner valley are based primarily on interpretation of aerial photography and geologic mapping, supplemented by geotechnical borehole data compiled from existing databases and logs on file with municipal, state, and federal agencies. The groundwater maps are based on analysis of water-level data from well catalogs, the geotechnical borehole database, shallow drive-point well data, and water-level elevations in drainage ditches.

\section{Floodplain Materials and Water-table Depths}

The inner Rio Grande valley is underlain primarily by saturated, unconsolidated sandy alluvium deposited by the Rio Grande and tributary arroyos (fig. T-1). This alluvium consists predominantly of sand and gravel with discontinuous interbeds of silt and clay. Borehole data from these deposits show that most have low Standard Penetration Test (SPT) blow counts. The valley also contains levees, embankments and other man-made features composed of engineered and non-engineered artificial fill. Groundwater in the inner valley is quite shallow and generally less than $12 \mathrm{~m}$ ( $40 \mathrm{ft}$ ) beneath most of the valley (fig. T-2). We use the shallowest recorded historic water level in our analysis so that our assessments of liquefaction susceptibility are conservative. Historic declines in groundwater levels near downtown Albuquerque related to pumping would reduce some of the liquefaction susceptibilities. Lesser historic groundwater-level declines in the areas north of Albuquerque (i.e., from Bernalillo to Alameda) and south of Albuquerque (i.e., from Armijo to Isleta Pueblo) suggest that liquefaction susceptibilities in these areas have not been affected by groundwater withdrawals.

\section{Liquefaction Susceptibility}

Large areas of the inner Rio Grande valley near Albuquerque are susceptible to liquefaction (fig. T-3), based on our synthesis of the geologic, geotechnical, and groundwater data. Areas 


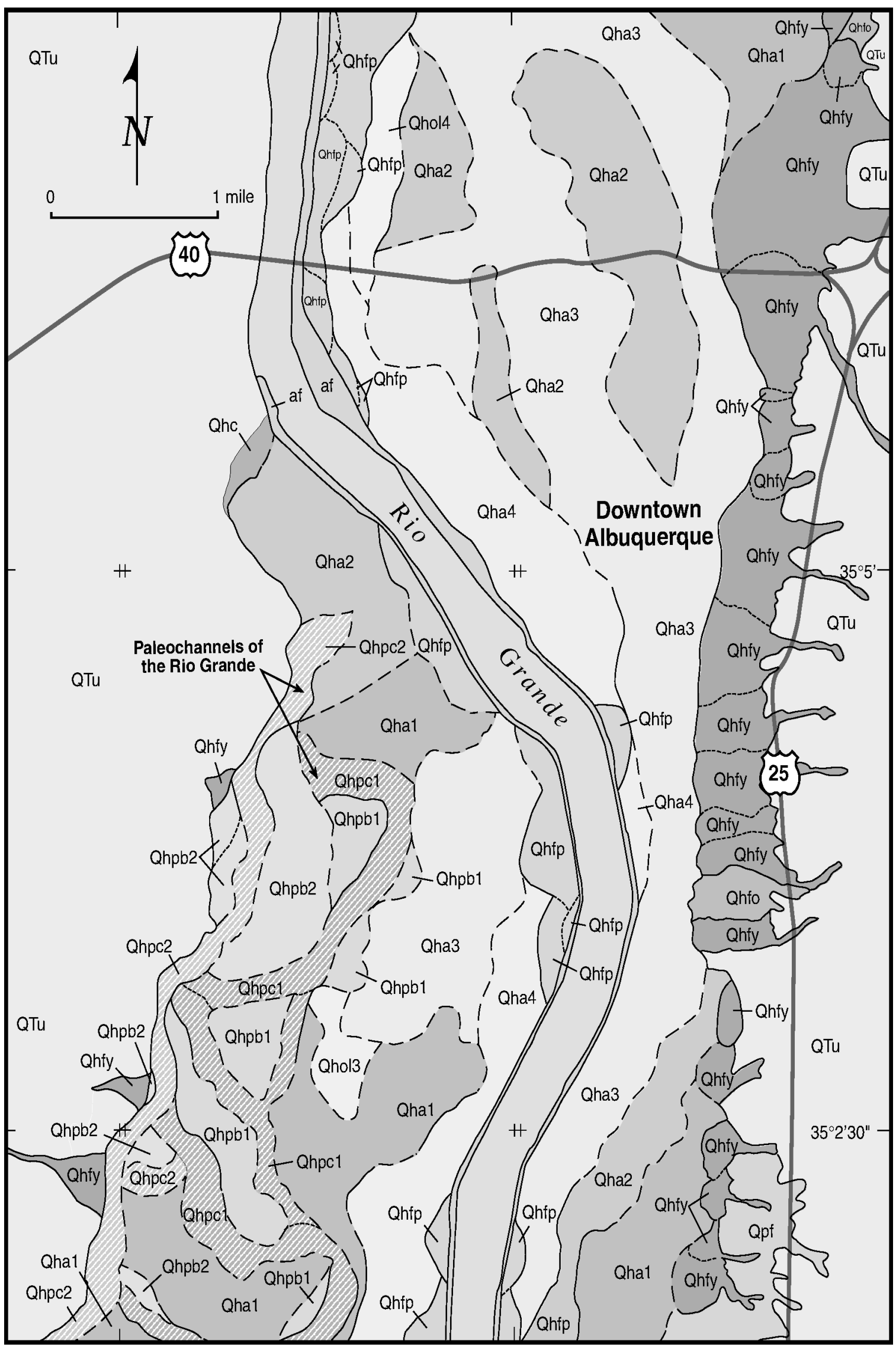

Figure T-1. Surfical geologic map of part of the Albuquerque West quadrangle. Units designated by following notation; Q: Quaternary, P: Pleistocene, fp: floodplain, a: alluvium:pc: paleochannel, ol: overbank levee, pb: point bar, e: eolian, fy: young alluvial fan,fo: old alluvial fan, c: colluvium, af: artifical fill. Numerals indicate relative age of units, with 1=oldest and $4=y o u n g e s t$. 
underlain by deposits that may liquefy given a peak ground acceleration (PGA) of $0.1 \mathrm{~g}$ or less (based on a magnitude 7.0 earthquake) are classified as Very High susceptibility. In the inner valley, these areas include the saturated sandy alluvium associated with the present-day channel and active floodplain of the Rio

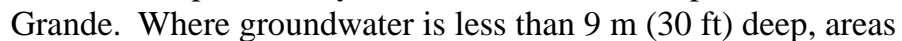
of artificial fill associated with levees and embankments are conservatively classified as Very High susceptibility. Areas that show

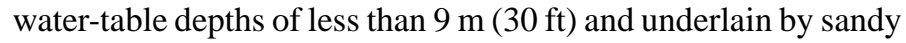
alluvium that may liquefy with a PGA of $0.2 \mathrm{~g}$ (based on a magnitude 7.0 earthquake) are classified as High susceptibility. Less extensive areas of the inner valley have deeper water table and (or) are underlain by older, more consolidated deposits that are less susceptible to liquefaction, and are classified as Moderate or Low susceptibility. Upland areas adjacent to the inner valley generally are classified as Low or Very Low susceptibility, largely because the water table is much deeper.

Overall, the areas classified as Very High or High liquefaction susceptibility include most of the inner Rio Grande valley. This area involves roughly 240 square kilometers (90 square miles) within the valley north and south of Albuquerque. Downtown Albuquerque is classified as areas of High susceptibility (roughly southwest of the intersection of Silver Avenue and Sixth Street) and Moderate susceptibility (roughly southwest of the intersection of Marquette Avenue and First Street).

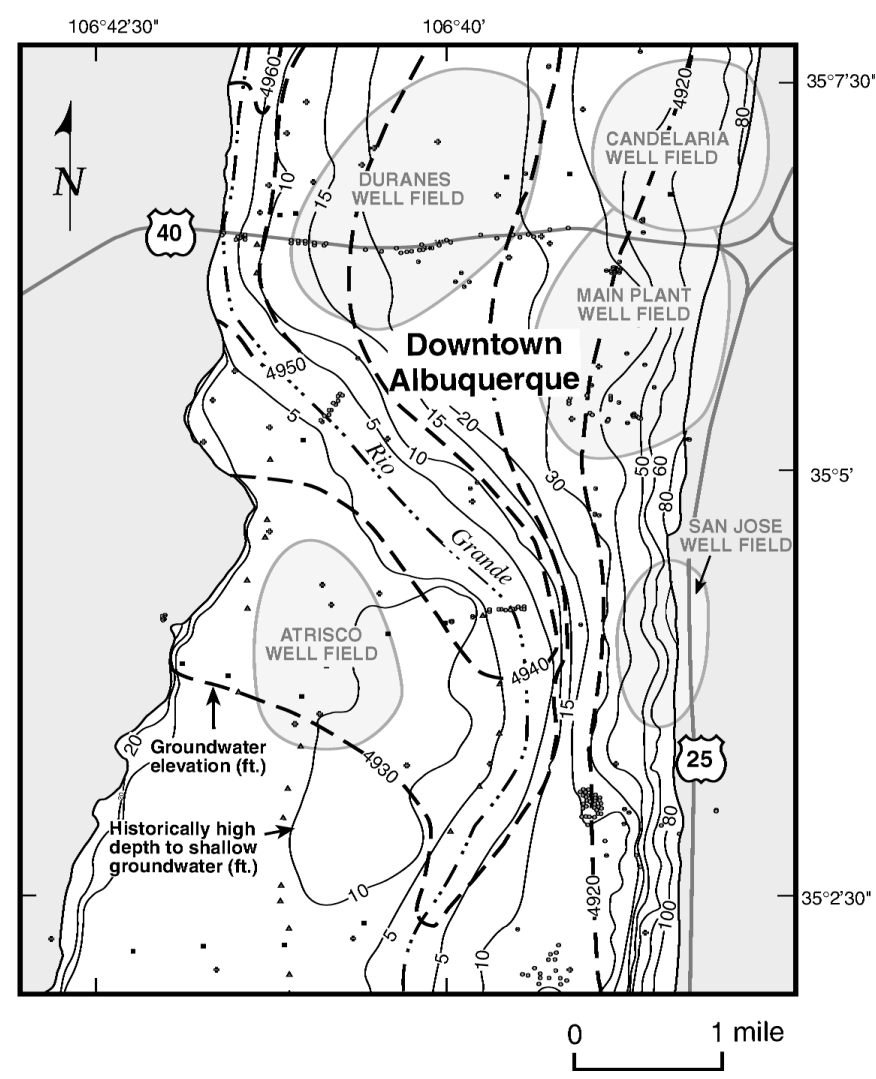

Figure T-2. Groundwater elevation map (dashed lines) and depth-to groundwater contour map (solid lines) of part of the Albuquerque West quadrangle. Data points from shallow boreholes, drainage ditches, and drive-point wells (Kelson et al.,)
The zones identified herein as Very High or High susceptibility encompass the areas most likely to experience liquefactionrelated damage from a moderate to large earthquake in central New Mexico. Overall, it is reasonable to assume that large areas of the inner valley will be affected by liquefaction-related damage. Site-specific geotechnical investigations should be per-

formed in areas of Very High or High susceptibility to assess risk to existing facilities and to evaluate and mitigate liquefaction hazards.

This research was supported by U.S. Geological Survey (USGS), Department of the Interior, under USGS award number 98-HQ-GR-1009, for the National Earthquake Hazard Reduction Program. The views and conclusions contained in this document are those of the authors and should not be interpreted as necessarily representing the official policies, either expressed or implied, of the U.S. Government.

\section{Reference}

Kelson, K.I., Hitchcock, C.S., and Randolph, C.E, 1999, Liquefaction Susceptibility in the Inner Rio Grande Valley Near Albuquerque, New Mexico: unpublished final technical report, U.S. Geological Survey National Earthquake Hazards Reduction Program, Award Number 98-HQ-GR-1009, 40 p., 9 plates, scale 1:24,000.

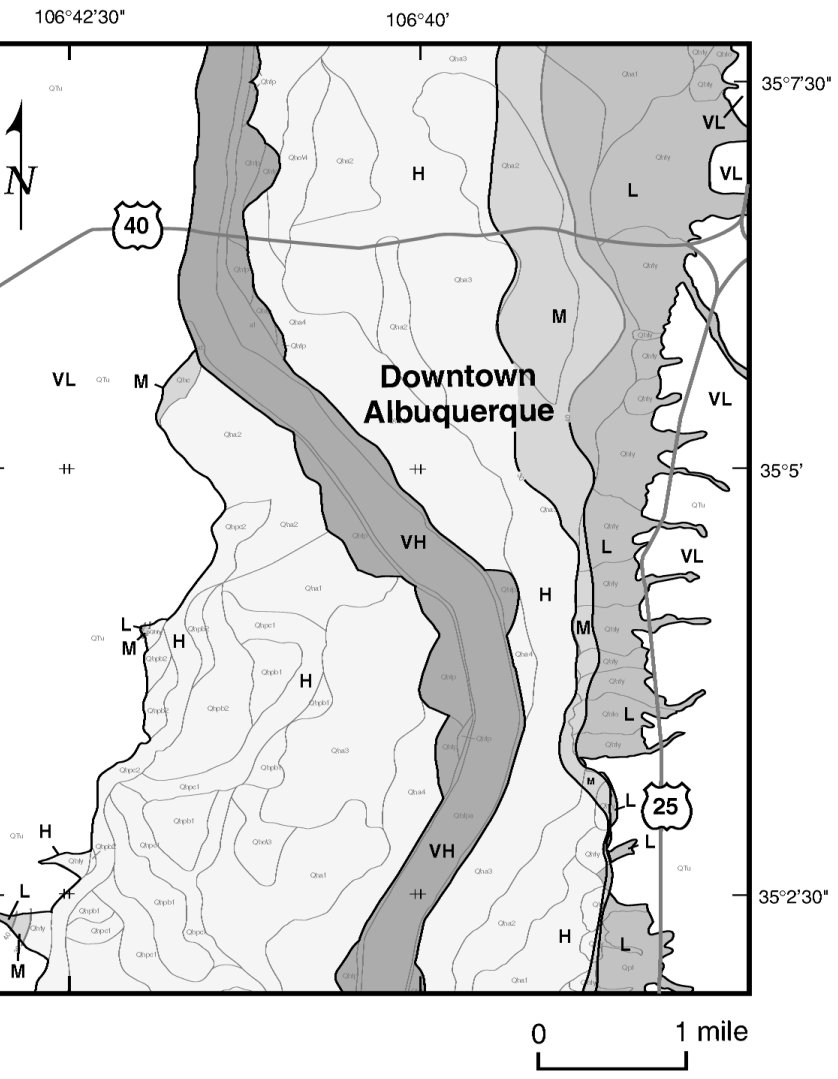

Figure T-3. Liquefaction susceptibility of part of the Albuquerque West quadrangle (VH: very High, H: High, M: Moderate, L: Low, VL: very Low). 


\title{
U. New Mexico District Cooperative Program in the Middle Rio Grande Basin, FY2000
}

\author{
Dennis G. Woodward \\ U.S. Geological Survey, Albuquerque NM
}

\section{Introduction}

The New Mexico District of the U.S. Geological Survey (USGS) has established and fostered for many decades a dynamic Cooperative Water Program in the Middle Rio Grande Basin, central New Mexico. In the Cooperative Water Program, investigative projects and data-collection activities are jointly identified, planned, and funded by the USGS and by State and local agencies. Generally, the State and local agencies provide at least one-half the funds, and the USGS does most of the work. The collective results of the Cooperative Program have provided the scientific basis and the institutional framework for developing the USGS Middle Rio Grande Basin Study that began in fiscal year 1996. This article briefly describes the historical highlights of the Cooperative Program in the Middle Rio Grande Basin and the components of the present program. Of the approximate $\$ 2.8$ million allocated in fiscal year 2000 for USGS work in the basin, about $\$ 0.8$ million was from the Cooperative Program. The major agencies in the Cooperative Program in the basin study are the City of Albuquerque (City), the New Mexico Office of State Engineer (OSE), and Bernalillo County.

\section{History}

One of the earliest highlights of the Cooperative Program in the Middle Rio Grande Basin was the report on the availability of ground water in the Albuquerque area by Bjorklund and Maxwell (1961). They presented regional maps of the geology and watertable configuration in the area. Reeder and others (1967) provided a quantitative analysis of the water resources in the Albuquerque area, with calculated effects on the Rio Grande from ground-water pumpage. They presented projected water-table declines and depletions of Rio Grande flow due to projected ground-water withdrawals. Most of the Cooperative Program during the succeeding period was primarily devoted to data-collection activities.

\section{Ground-water Flow-Modeling}

During the last decade, the most significant milestone in the Cooperative Program with the City of Albuquerque has been development, construction, and documentation of ground-waterflow models for the Albuquerque Basin. Thorn and others (1993) described the geohydrologic framework and hydrologic conditions used in the flow model, and Kernodle and others (1995) presented the results of the flow model. McAda (1996) detailed a plan of study to quantify the hydrologic relations between the Rio Grande and the Santa Fe Group aquifer system in the Albuquerque area; 13 essential activities and informational needs were identified and prioritized. The most recent highlights of the Cooperative Program have been the drilling, completion, and monitoring of a series of nested piezometers located throughout the Albuquerque area. These nests commonly have piezometers that measure water levels near the water table, near the middle of the "production zone", and near the base of the "production zone" for City wells. By the end of calendar year 1999, 19 such piezometer nests were completed at 17 sites.

\section{Current Activities}

The current (FY2000) Cooperative Program with the City contains the following components: (1) assistance to the Upper Rio Grande Water Operations Model; (2) continuation of the ground-water-level monitoring network; (3) expansion of the ground-water-level monitoring network by completion of more nested piezometers; (4) preparation of the final report on the estimation of seepage rates from the Rio Grande, canals, and drains in the Albuquerque area; (5) monitoring of low-flow conditions in urban storm drains; (6) assessment of water-quality trends in City production wells; (7) dissemination of hydrologic information over the Internet; (8) update of the regional ground-water-flow model; (9) slug testing of the City piezometer nests; (10) hydrologic trends in the Rio Grande; and (11) investigation of aquifer compaction and land subsidence. Many of these activities focus on quantifying hydrologic relations between the Rio Grande and the aquifer system, as identified in the McAda (1996) plan. The current (FY2000) Cooperative Program with the OSE contains the following components: (1) revision of the Albuquerque Basin ground-water-flow model; (2) estimation of physical and hydraulic characteristics of canals and drains; (3) ground-water-level monitoring of selected nested piezometers; and (4) continuation of the long-term ground-water-level monitoring network. The FY2000 Cooperative Program with Bernalillo County provides for the drilling and completion of a deep piezometer nest.

\section{References}

Bjorklund, L.J., and Maxwell, B.W., 1961, Availability of ground water in the Albuquerque area, Bernalillo and Sandoval Counties, New Mexico: New Mexico State Engineer Technical Report 21, 117 p.

Kernodle, J.M., McAda, D.P., and Thorn, C.R., 1995, Simulation of groundwater flow in the Albuquerque Basin, central New Mexico, 19011994, with projections to 2020: U.S. Geological Survey WaterResources Investigations Report 94-4251, 114 p., 1 pl. 
McAda, D.P., 1996, Plan of study to quantify the hydrologic relations between the Rio Grande and the Santa Fe Group aquifer system near Albuquerque, central New Mexico: U.S. Geological Survey Water-Resources Investigations Report 96-4006, 58 p.

Reeder, H.O., Bjorklund, L.J., and Dinwiddie, G.A., 1967, Quantitative analysis of water resources in the Albuquerque area, New Mexico-
Computed effects on the Rio Grande of pumpage of ground water, 1960-2000: New Mexico State Engineer Technical Report 33, 34 p.

Thorn, C.R., McAda, D.P., and Kernodle, J.M., 1993, Geohydrologic framework and hydrologic conditions in the Albuquerque Basin, central New Mexico: U.S. Geological Survey Water-Resources Investigations Report 93-4149, $106 \mathrm{p}$.

\title{
V. Partitioning of Dextral Slip in an Incipient Transverse Shear Zone of Neogene Age, Northwestern Albuquerque Basin, Rio Grande rift, New Mexico
}

\author{
Richard M. Chamberlin \\ New Mexico Bureau of Mines and Mineral Resources, New Mexico Tech, Socorro NM 87801
}

\section{Introduction}

Recent geologic mapping near the northwest margin of the Albuquerque Basin (Loma Creston quadrangle) has revealed a subtle ENE-trending zone of distributed dextral shear between Bodega Butte and Mesita Cocida. The Bodega-Cocida transverse zone (BCTZ) is expressed as a $1.5 \mathrm{~km}$-wide belt of deflections, splays and terminations within the dominant northerly-striking system of high-angle normal faults that controlled Neogene basin subsidence. Restored cross sections near Loma Creston indicate about $5-10 \%$ westerly-directed extension.

\section{Geologic Setting}

Gently tilted basin fill strata consist of fluvial siliciclastic sediments and alluvial volcaniclastic sediments locally intercalated with basaltic to rhyolitic lavas and tuffs erupted from the southern periphery of the Jemez volcanic field. Published radiometric dates of correlative volcanic units range from about 10.4 Ma to 2.5 Ma. Footwall blocks of longitudinal rift faults are locally expressed in the landscape as north-trending ridges of hydrothermal silicification. Alteration patterns suggest two episodes of southerly fault-guided hydrothermal flow spatially linked to rhyolitic eruptive centers dated at about $10 \mathrm{Ma}$ and $7 \mathrm{Ma}$.

\section{Fault Kinematics}

Sliplines (striations and secondary "Riedel" shears) are locally well preserved and exposed on silicified faces of the Neogene rift faults. Fault slip observations $(\mathrm{n}=12)$ suggest the following pattern: predominant east-down high-angle normal faults, which exhibit throws of 100-500 m, are essentially dipslip and commonly show a minor component of dextral slip (striae pitch $78-87^{\circ} \mathrm{S}$ ). Within the Bodega-Cocida zone, NNEstriking high-angle normal faults of moderate throw $(10-60 \mathrm{~m})$ show dextral oblique slip (striae pitch $28-52^{\circ} \mathrm{S}$ on east-down faults and $11-63^{\circ} \mathrm{N}$ on west-down faults). Two NNE-striking subvertical dextral-slip faults (striae pitch at $2-8^{\circ} \mathrm{N}$ ) are well exposed in an incipient antithetic accommodation zone where opposing dextral oblique faults partially overlap on the south flank of Mesita Cocida.

The Bodega-Cocida transverse zone is aligned with the Tenorio/Jemez relay ramp ( $25 \mathrm{~km}$ to $\mathrm{SW}$ ) and the NE-trending segment of the Pajarito fault (15 km to NE). This regional pattern suggests localized reactivation of an ENE-trending basement shear zone. Dextral-oblique extension within the Bodega-Cocida transverse zone can be explained as a result of minor counterclockwise rotation of en echelon blocks above a zone of sinistral-oblique ductile extension in hot (migmatitic) middle crust. 